\title{
Geological relationships and laser ablation ICP-MS U-Pb geochronology of the Saint George Batholith, southwestern New Brunswick, Canada: implications for its tectonomagmatic evolution
}

\author{
Nadia Mohammadi ${ }^{1 *}$, Les FyfFe ${ }^{2}$, Christopher R.M. McFarlane ${ }^{1}$, Kay G. Thorne ${ }^{2}$, David R. LentZ ${ }^{1}$,

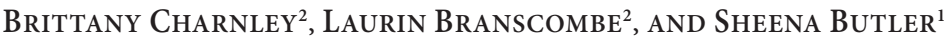 \\ 1. Department of Earth Sciences, University of New Brunswick, Fredericton, New Brunswick E3B 5A3, Canada \\ 2. Geological Surveys Branch, New Brunswick Department of Energy and Resource Development, Fredericton, \\ New Brunswick E3B 5H1, Canada \\ *Corresponding author $<$ nadia.mohammadi@unb.ca $>$
}

Date received: 03 November 2016 Date accepted: 07 April 2017

\begin{abstract}
The Late Silurian to Late Devonian Saint George Batholith in southwestern New Brunswick is a large composite intrusion $\left(2000 \mathrm{~km}^{2}\right)$ emplaced into the continental margin of the peri-Gondwanan microcontinent of Ganderia. The batholith includes: (1) Bocabec Gabbro; (2) equigranular Utopia and Wellington Lake biotite granites; (3) Welsford, Jake Lee Mountain, and Parks Brook peralkaline granites; (4) two-mica John Lee Brook Granite; (6) Jimmy Hill and Magaguadavic megacrystic granites; and (6) rapakivi Mount Douglas Granite. New LA ICP-MS in situ analyses of six samples from the Saint George Batholith are as follows: (1) U-Pb monazite crystallization age of $425.5 \pm 2.1 \mathrm{Ma}$ for the Utopia Granite in the western part of the batholith (2) U-Pb zircon crystallization ages of $420.4 \pm 2.4 \mathrm{Ma}$ and 420.0 $\pm 3.5 \mathrm{Ma}$ for two samples of the Utopia Granite from the central part of the batholith; (3) U-Pb zircon crystallization age of 418.0 $\pm 2.3 \mathrm{Ma}$ for the Jake Lee Mountain Granite; (4) U-Pb zircon crystallization age of $415.5 \pm 2.1$ Ma for the Wellington Lake Granite; and (5) U-Pb monazite crystallization age of $413.3 \pm 2.1 \mathrm{Ma}$ for the John Lee Brook Granite. The new geochronological together with new and existing geochemical data suggest that the protracted magmatic evolution of the Late Silurian to Early Devonian plutonic rocks is related to the transition of the Silurian Kingston arc-Mascarene backarc system from an extensional to compressional tectonic environment during collision of the Avalonian microcontinent with Laurentia followed by slab break-off.
\end{abstract}

\section{RÉSUMÉ}

Le batholite du Silurien tardif au Dévonien tardif de Saint George dans le sud ouest du Nouveau Brunswick est une vaste intrusion composite (2 000 kilomètres carrés) qui sest mise en place à l'intérieur de la marge continentale du microcontinent périgondwanien de Ganderia. Le batholite englobe : (1) le gabbro de Bocabec; (2) les granites à biotite isogranulaire Utopia et du lac Wellington; (3) les granites hyperalcalins de Welsford, du mont Jake Lee et du ruisseau Parks Brook; (4) le granite à deux micas du ruisseau John Lee; (5) les granites macrocristallins de la colline Jimmy et de Magaguadavic; et (6) le granite rapakivi du mont Douglas. De nouvelles analyses par spectrométrie de masse à plasma induit couplée à lablation laser in situ de six échantillons provenant de Saint George ont révélé ce qui suit : (1) une cristallisation survenue il y a 425,5 $\pm 2,1$ Ma d'après une datation U-Pb sur monazite, dans le cas du granite Utopia dans la partie occidentale du batholite; (2) des âges de cristallisation en vertu d'une datation U-Pb sur zircon de 420,4 $\pm 2,4 \mathrm{Ma}$ et de 420,0 $\pm 3,5 \mathrm{Ma}$ dans le cas de deux échantillons en provenance du granite Utopia dans le centre du batholite; (3) un âge de cristallisation de 418,0 $\pm 2,3$ Ma dans le cas du granite du mont Jake Lee, d'après une datation U-Pb sur zircon; (4) un âge de cristallisation de 415,5 $\pm 2,1$ Ma obtenu par datation U-Pb sur zircon dans le cas du granite du lac Wellington; et (5) un âge de cristallisation de 413,3 $\pm 2,1$ Ma d’après une datation U-Pb sur monazite, dans le cas du granite du ruisseau John Lee. Les nouvelles données géochronologiques conjuguées aux données géochimiques existantes laissent supposer que lévolution magmatique prolongée de des roches plutoniques du Silurien tardif au Dévonien précoce est apparentée à la transition de larc silurien de Kingston-arrière-arc de Mascarene d'un milieu tectonique de distension à un milieu de compression durant la collision du microcontinent avalonien avec Laurentia suivie d'une rupture par tranches.

[Traduit par la redaction] 


\section{INTRODUCTION}

The Silurian (Ludlovian to Pridolian) to Late Devonian (Famennian) Saint George Batholith in southwestern New Brunswick is a large composite intrusion $\left(2000 \mathrm{~km}^{2}\right)$ that was emplaced into the margin of the peri-Gondwanan microcontinent of Ganderia (Fig. 1). The batholith and associated Silurian volcanic and sedimentary rocks of the Mascarene belt are situated along the boundary between Precambrian Ganderian basement rocks of the New River and Brookville belts to the southeast and Ganderian passive margin Cambrian-Ordovician sedimentary rocks of the St. Croix belt to the northwest (Fyffe and Riva 1990; van Staal et al. 2009; Fyffe et al. 2011). The presence of Proterozoic marble and quartzite in the Brookville belt distinguishes it from the Neoproterozoic volcanic and comagmatic plutonic rocks of the New River belt (Johnson and McLeod 1996; White and Barr 1996). The St. Croix belt is a highly deformed Cambrian-Ordovician (Tremadocian to Sandbian) sequence of shale, wacke, and quartzose sandstone; the Fredericton belt is a thick Silurian
(Llandoverian to Ludlovian) sequence of wacke, shale, and calcareous sandstone (Ruitenberg 1967; Fyffe and Riva 2001; Castonguay et al. 2003; Thorne et al. 2008). The precise nature of the contact between the St. Croix and Fredericton belts is difficult to discern in the field due to poor exposure, complex deformation, and similarity of lithotypes. The contact has been interpreted as a northwest-directed thrust, referred to as the Honeydale Fault (Ruitenberg 1967).

Silurian (Llandoverian) volcanic and comagmatic plutonic rocks of the Kingston belt separate the Brookville belt from the New River belt. Felsic volcanic rocks in the Kingston belt have yielded $\mathrm{U}-\mathrm{Pb}$ zircon ages ranging from 442 to $436 \mathrm{Ma}$, and associated felsic plutonic rocks, ranging from 437 to $435 \mathrm{Ma}$ (Doig et al. 1990; Barr et al. 2002; McLeod et al. 2003). These volcanic and plutonic rocks are interpreted, based on geochemical characteristics, to represent remnants of a Silurian volcanic arc that formed above a subduction zone dipping to the northwest beneath the New River belt (Fyffe et al. 1999; Barr et al. 2002; White et al. 2006). The shallow marine to subaerial sedimentary and volcanic sequences of the Silurian (Llandoverian to

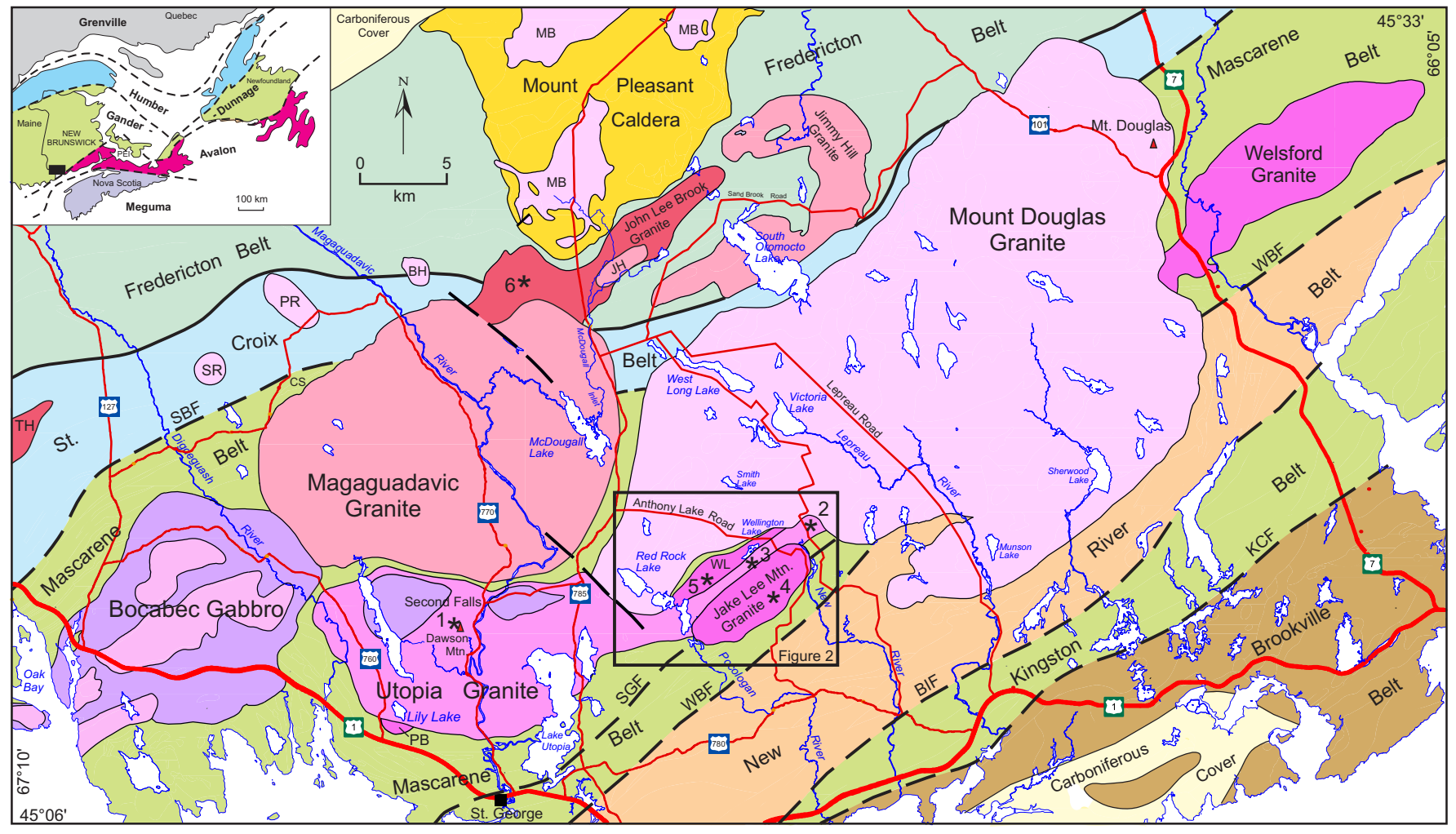

Figure 1. Map of geological belts and plutonic rocks in southwestern New Brunswick, Canada; the Caledonia Fault along the southeast side of the Brookville belt (outside of area of Figure 1) defines the boundary between Ganderia and Avalonia. Inset map shows tectonostratigraphic terranes in the northeastern Appalachians (after Hibbard et al. 2006) with location of Figure 1 outlined by a black block on insert. Location of Figure 2 is shown by outlined rectangle. Major plutons comprising the Saint George Batholith are named in full. Abbreviations: BIF = Belleisle Fault; KCF = Kennebecasis Fault; SGF = St. George Fault; WBF = Wheaton Brook Fault; BH = Beech Hill Granite; MB = McDougall Brook Granite; PR = Pleasant Ridge Granite; SR = Sorrel Ridge Granite; TH = Tower Hill Granite; JH = Jimmy Hill Granite; PB = Parks Brook Granite; WL = Wellington Lake Granite; CS = Clarence Stream gold deposit. Granitic rocks in the Bocabec Gabbro are shown in pink and gabbroic rocks in the Utopia Granite are shown in purple. Asterisk shows location of dated samples in the Saint George Batholith: $1=171-6 ; 2$ = 15-87; 3 = 15-104; 4 = JL16-1; $5=15-72 ; 6=85$ MM-154B. 
Pridolian) Mascarene belt, lying to the northwest of the Kingston belt, are interpreted to have been deposited in a backarc basin that opened behind the Kingston arc (Fyffe et al. 1999; Barr et al. 2002). Felsic volcanic rocks from the Mascarene belt have yielded $\mathrm{U}-\mathrm{Pb}$ zircon ages ranging from 438 to $423 \mathrm{Ma}$ (Miller and Fyffe 2002; Van Wagoner et al. 2002).

Based on field relationships and geochronological data, McLeod (1990) divided the Saint George Batholith into the following units from oldest to youngest (Fig. 1): Bocabec Gabbro - greyish green, locally layered, medium-grained gabbro and minor associated granitic rocks; Utopia Granite - typically red, leucocratic, medium- to coarse-grained, equigranular, biotite granite; Welsford, Jake Lee Mountain, and Parks Brook granites - beige to pink, mediumgrained and equigranular to fine-grained and porphyritic, amphibole-bearing, peralkaline granites; Magaguadavic Granite - greyish pink, coarse-grained, megacrystic granite; John Lee Brook Granite - light grey, medium-grained, equigranular, garnetiferous, two-mica granite; and Mount Douglas Granite - light pink, medium-to-coarse-grained and equigranular to fine-grained and porphyritic, rapakivitextured, biotite granite. Geochronological data available to McLeod (1990) included: U-Pb zircon ages from the Utopia $(430 \pm 3 \mathrm{Ma})$, Welsford (422 $\pm 1 \mathrm{Ma})$, and Magaguadavic $\left(396 \pm 1 \mathrm{Ma}\right.$ ) granites; an ${ }^{40} \mathrm{Ar} /{ }^{39} \mathrm{Ar}$ muscovite age of $384 \pm$ $7 \mathrm{Ma}$ from the John Lee Brook Granite; and U-Pb monazite ages from the Mount Douglas granite $(367 \pm 1 \mathrm{Ma}, 366 \pm$ $1 \mathrm{Ma})$.

To provide additional crystallization ages for the plutons comprising the Saint George Batholith, six samples were selected for laser ablation inductively coupled plasma-mass spectrometry (LA ICP-MS) analysis at the University of New Brunswick's Department of Earth Sciences. The U-Pb geochronological work was coordinated with field mapping of the Saint George Batholith by the Geological Surveys Branch of the New Brunswick Department of Energy and Resource Development during the summers of 2015 and 2016. Dated sample sites (Locations 1 through 6, numbered from oldest to youngest age of crystallization) are shown on Figure 1 and Figure 2. Locations 1, 4, 5 and 6 are in the Utopia, Jake Lee Mountain, Wellington Lake (new name), and John Lee Brook granites, respectively. Locations 2 and 3, previously mapped as part of the Mount Douglas Granite and Jake Lee Mountain Granite, respectively (McLeod 1990, McLeod et al. 1998), are here assigned to the Utopia Granite on the basis of new field mapping (see below).

\section{FIELD OBSERVATIONS}

In 2015, geochronological analysis of an archived sample from the John Lee Brook Granite indicated that this twomica granite is older than the megacrystic Magaguadavic Granite rather than younger as previously suggested (McLeod 1990). Field work was therefore undertaken in the summers of 2015 and 2016 to resolve the conflict

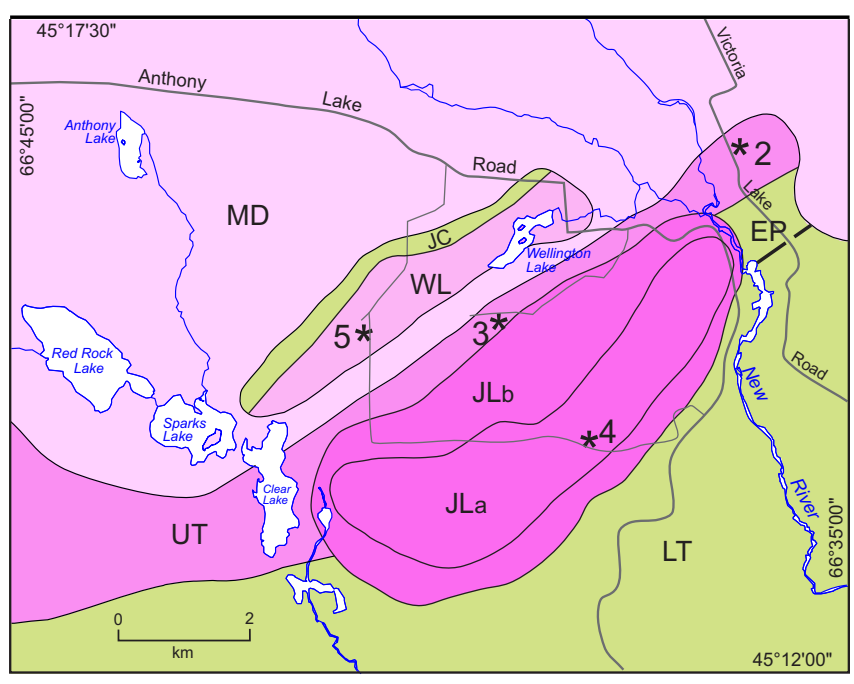

Figure 2. Detailed geology of Wellington Lake - New River area (see Figure 1 for location). Abbreviations: EP = Eastport Formation; JC = Jones Creek Formation; LT = Letete Formation; $\mathrm{JL}=$ Jake Lee Mountain Granite (a) coarse-grained, (b) fine-grained; $M D=$ Mount Douglas Granite; WL = Wellington Lake Granite; UT = Utopia Granite. Asterisk shows location of dated samples: $2=15$ $87 ; 3=15-104 ; 4=$ JL16- $1 ; 5=15-72$.

between the previously interpreted intrusive history of the Saint George Batholith and the new geochronological data. Contact relationships between the various plutons comprising the Saint George Batholith were examined and the new findings are reported below and incorporated into the revised regional map of the batholith (Fig. 1). Detailed mapping of contacts between intrusive and country rocks during our recent mapping has also better defined the areal distribution and geometry of the plutons comprising the batholith. Previous maps depicted the Saint George Batholith as a contiguous assemblage of intrusions that were emplaced over an extended period of time to form a single massive body. The new mapping, however, suggests that the batholith is more realistically comprised of a loose cluster of distinctive plutons that intruded mainly into sedimentary and volcanic host rocks rather than into previously consolidated intrusive bodies (Fig. 1).

McLeod (1990) recognized and named the poorly exposed John Lee Brook Granite as a distinct pluton during his mapping of the Saint George Batholith. It is a mediumgrained, equigranular, garnetiferous, two-mica granite, underlying an area of about $50 \mathrm{~km}^{2}$ along the northern margin of the batholith just south of the Late Devonian Mount Pleasant Caldera (Thorne et al. 2013). The ${ }^{40} \mathrm{Ar} /$ ${ }^{39} \mathrm{Ar}$ muscovite age of $384 \pm 7 \mathrm{Ma}$ from the John Lee Brook Granite together with the reported presence of white microgranitic veins cutting the adjacent Magaguadavic Granite, dated by U-Pb on zircon at $396 \pm 1 \mathrm{Ma}$ (Bevier 1990), suggested that the former was younger than the latter (McLeod 1990). However, dating of sample 85MM-154B, collected by McLeod (1990) from near the headwaters 
of John Lee Brook, yielded a crystallization age of $413 \pm$ $2 \mathrm{Ma}$ (Location 6 on Fig. 1) casting doubt on the above interpretation.

Field observations undertaken in the summer of 2015 on a small isolated body of megacrystic granite exposed along the upper reaches of McDougall Inlet, west of South Oromocto Lake (Fig. 1), indicate that the megacrystic granite intrudes and truncates quartz veins and aplitic dykelets within the John Lee Brook Granite (Fig. 3a). This isolated body is considered herein to be part of the larger Jimmy Hill Granite (Fig. 1), which underlies the South Oromocto Lake area to the east of McDougall Inlet; McLeod (1990) previously included the granite in the South Oromocto Lake area as part of the Magaguadavic pluton. A close-up photograph of the outcrop along McDougall Inlet clearly shows pink megacrysts of potassium feldspar with rapakivi mantling characteristic of the Jimmy Hill Granite
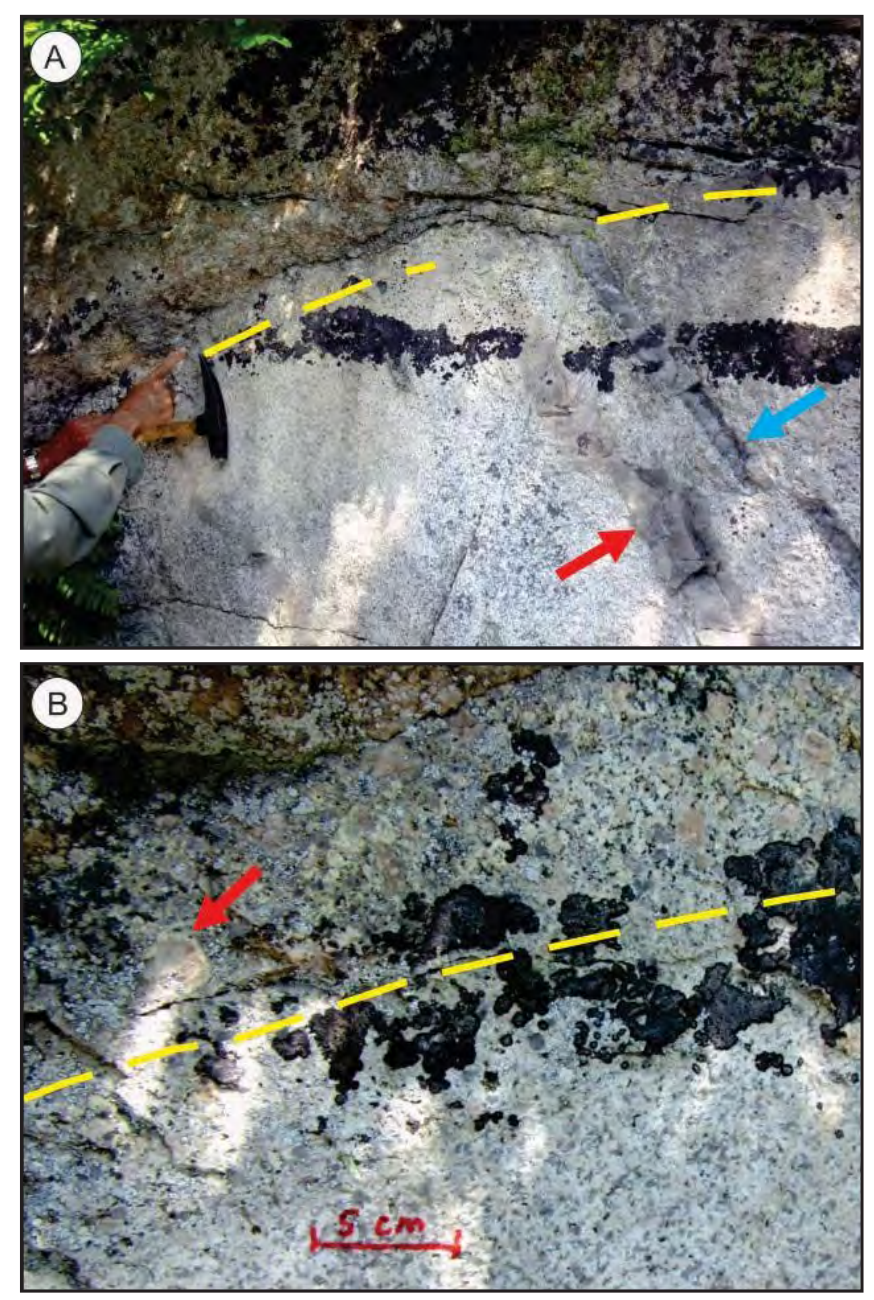

Figure 3. (a) Megacrystic Jimmy Hill Granite intruded into equigranular John Lee Brook Granite along West Branch McDougall Inlet. Quartz vein in the John Lee Granite is truncated by the Jimmy Hill Granite (latitude $45^{\circ} 24^{\prime} 39.7^{\prime \prime}$; longitude $\left.66^{\circ} 45^{\prime} 26.3^{\prime \prime}\right)$. (b) Close-up of the contact between pink rapakivi megacrystic Jimmy Hill Granite and white equigranular John Lee Brook Granite. in contact with the equigranular John Lee Brook Granite (Fig. 3b). The observed cross-cutting relationship confirms that both the megacrystic Jimmy Hill and Magaguadavic plutons, dated at $403 \pm 2 \mathrm{Ma}$ and $396 \pm 1 \mathrm{Ma}$, respectively (Bevier 1990; Davis et al. 2004), are younger than the John Lee Granite in agreement with new age determination obtained on the latter (see below).

Geophysical maps of the St. George area clearly outline the Magaguadavic pluton in the McDougall Lake area as a prominent, circular magnetic feature (King and Barr 2004). This magnetic signature has been used to draw contacts on previously published bedrock maps that enigmatically suggest that the Early Devonian megacrystic granite of the Magaguadavic pluton cross-cuts the adjacent Late Devonian rapakivi granite of the Mount Douglas pluton. However, the recent field mapping has shown that the two plutons are separated by a screen of sedimentary rocks from 300 to $400 \mathrm{~m}$ wide and so do not come into direct contact with one another as shown on earlier maps; thus, the Magaguadavic pluton in this area intruded sedimentary and volcanic rocks along its eastern margin - Ordovician quartzose sandstone of the Kendall Mountain Formation (Cookson Group) in the north and Silurian siltstone and mafic volcanic tuff assigned to the Jones Creek Formation (Mascarene Group) in the south - and the Mount Douglas pluton intruded the same screen of sedimentary and volcanic rocks of Jones Creek Formation along its western margin (Fig. 1). More details on the stratigraphy of the Mascarene Group are given below under the discussion on the tectonic evolution of the Mascarene backarc basin.

The Utopia Granite underlies an area of about $100 \mathrm{~km}^{2}$ along the southern margin of the Saint George Batholith. The northern margin of the Utopia pluton is separated from the southern margin of the Magaguadavic pluton by a screen from 300 to $600 \mathrm{~m}$ wide of dark grey siltstone and minor mafic tuff of the Silurian Jones Creek Formation exposed above Second Falls on the Magaguadavic River (Figs. 1, 4, and 5). Gabbroic rocks, exposed a short distance

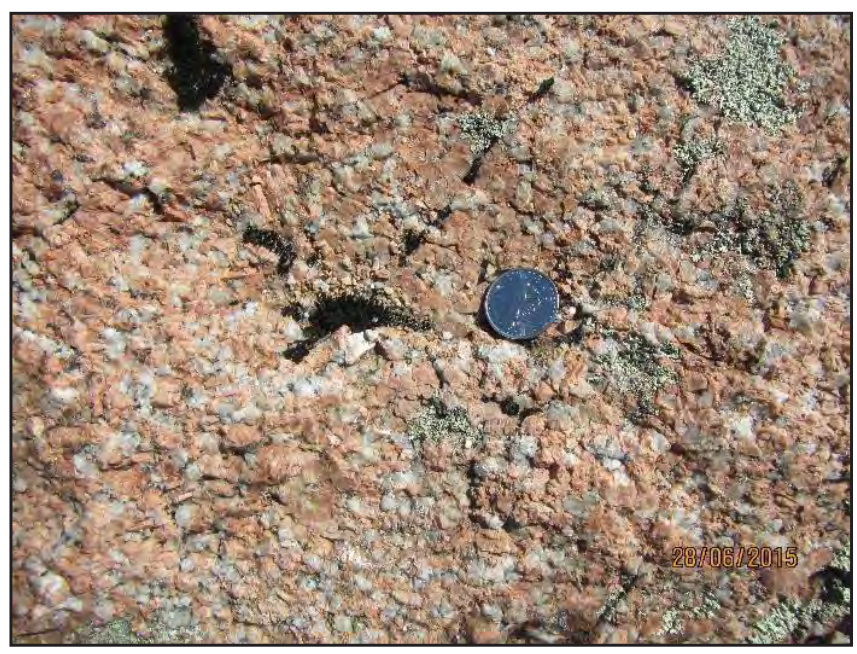

Figure 4. Red, medium-grained, equigranular granite of the Utopia Granite at Second Falls on the Magaguadavic River. 


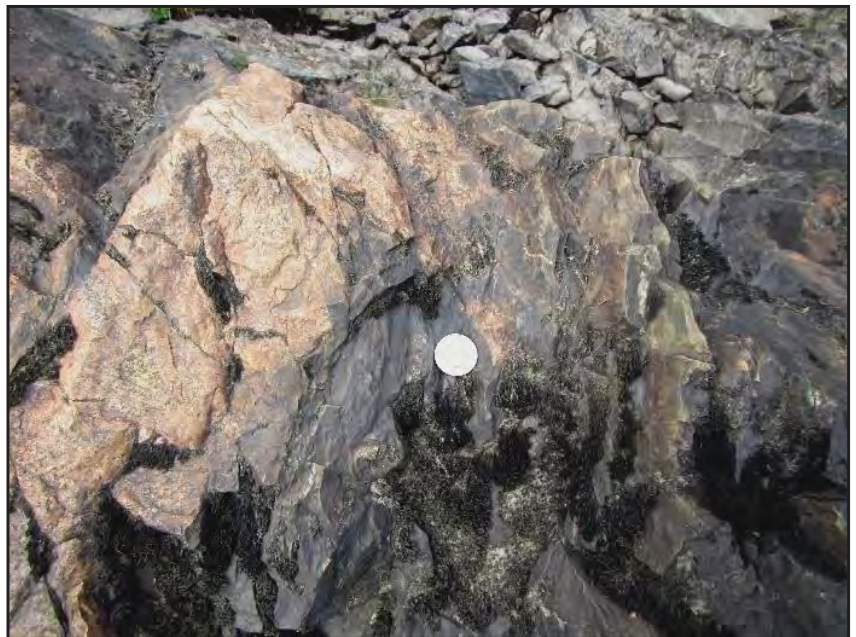

Figure 5. Inclusions of dark grey siltstone in red Utopia Granite about $2 \mathrm{~km}$ above Second Falls on the Magaguadavic River.

down river to the south, are injected by red granitic dykelets characteristic of the Utopia Granite; the granitic dykelets surround clusters of lobate gabbroic enclaves, many of which have fine-grained margins, suggesting that emplacement of the two magma types was essentially contemporaneous (Fig. 6). Similar magma mingling has been observed in the main part of the Bocabec Gabbro in the Oak Bay area (Fig. 1) farther to the southwest and in the Moosehorn Plutonic Suite in adjacent Maine (Fyffe 1971; McLaughlin et al. 2003). Note, however, that the new mapping suggests that a sedimentary screen exists between the Utopia and Bocabec plutons (Fig. 1), casting doubt on previous map interpretations showing a direct physical connection between gabbroic rocks in the Utopia pluton and those of the adjacent Bocabec pluton.

Bevier (1990) and Barr et al. (2010) reported U-Pb zircon ages of $430 \pm 3,428 \pm 1$, and $426 \pm 6 \mathrm{Ma}$ from samples of red Utopia Granite collected near the northern end of Lake Utopia (Fig. 1). These late Wenlockian to Ludlovian ages, according to the time scale of Ogg et al. (2016), seemed too old given that fossil evidence from sedimentary rocks in Maine indicate a Pridolian age (Churchill-Dickson 2004) for the surrounding Eastport Formation (Mascarene Group) and that felsic volcanic rocks in the Eastport Formation in New Brunswick have yielded a preliminary $\mathrm{U}-\mathrm{Pb}$ zircon age of $423 \pm 1$ Ma (Van Wagoner et al. 2002). However, the recent field mapping indicates that the Utopia pluton near the above dated granite may have been emplaced no higher in the stratigraphic section than the Llandoverian to Wenlockian Jones Creek Formation (Mascarene Group). To further investigate the age of the Utopia Granite, sample 171-6 was collected from a distinctive, light pink granite (Martin 2013) exposed on the summit of Dawson Mountain (Fig. 7) to the northwest of Lake Utopia (Location 1 on Fig. 1).

Field mapping was conducted in the Red Rock Lake area to the northeast of Lake Utopia (Fig. 1) to better delineate

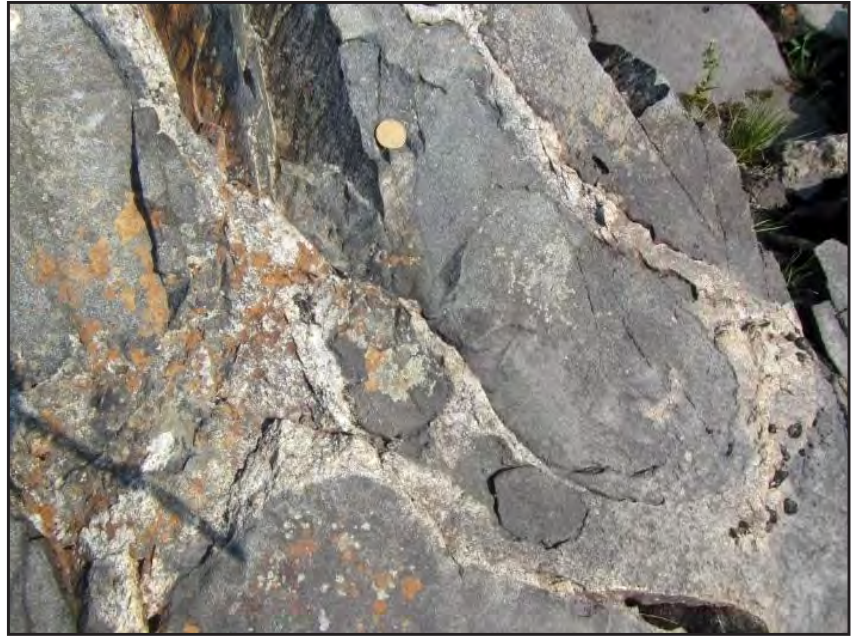

Figure 6. Dark grey, lobate enclaves gabbro injected by veins of red Utopia Granite about $1.8 \mathrm{~km}$ above Second Falls on the Magaguadavic River.

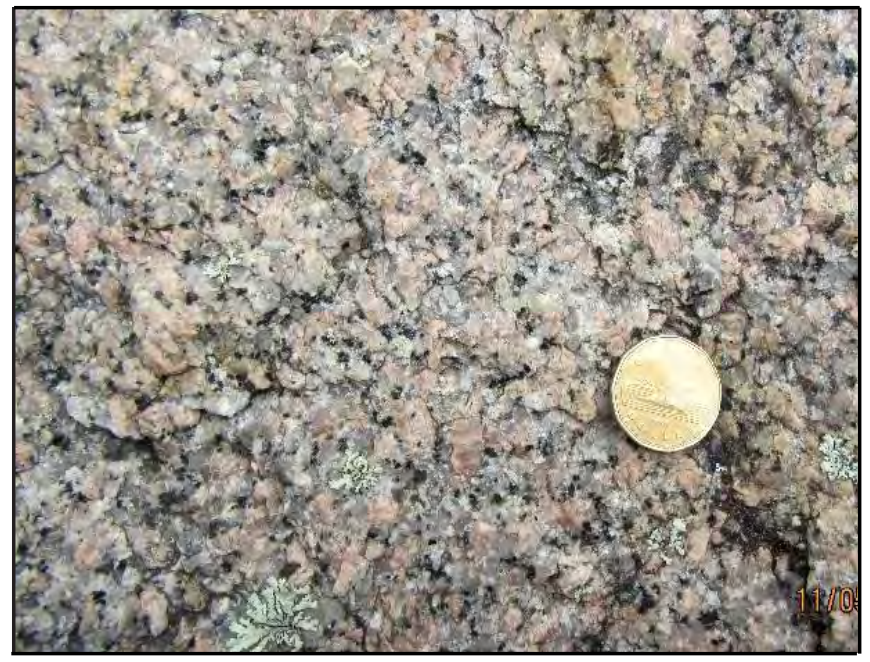

Figure 7. Light pink, medium-grained, equigranular granite of the Utopia Granite on Dawson Mountain (Location 1 on Fig. 1).

the contact between the Silurian Utopia Granite and Late Devonian Mount Douglas Granite. Distinguishing between these two granites can be difficult in places as both can vary from red to pink. However, as documented by Cherry and Trembath (1978), the granitic rocks in the Lake Utopia area are homogeneous, equigranular, and medium- to coarse-grained, whereas those in the Mount Douglas area are heterogeneous consisting of about $65 \%$ equigranular, medium- to coarse-grained phase and about 35\% finegrained porphyritic and aplitic phases. In addition, rapakivi-mantling of potassium feldspar is common in the granitic rocks in the Mount Douglas area (Fig. 8) - a feature that is rare in those of the Lake Utopia area (Cherry and Trembath 1978). These criteria were used to conclude that the Mount Douglas Granite extends farther south in the Red Rock Lake area (Fig. 1) than shown by McLeod (1990). This 


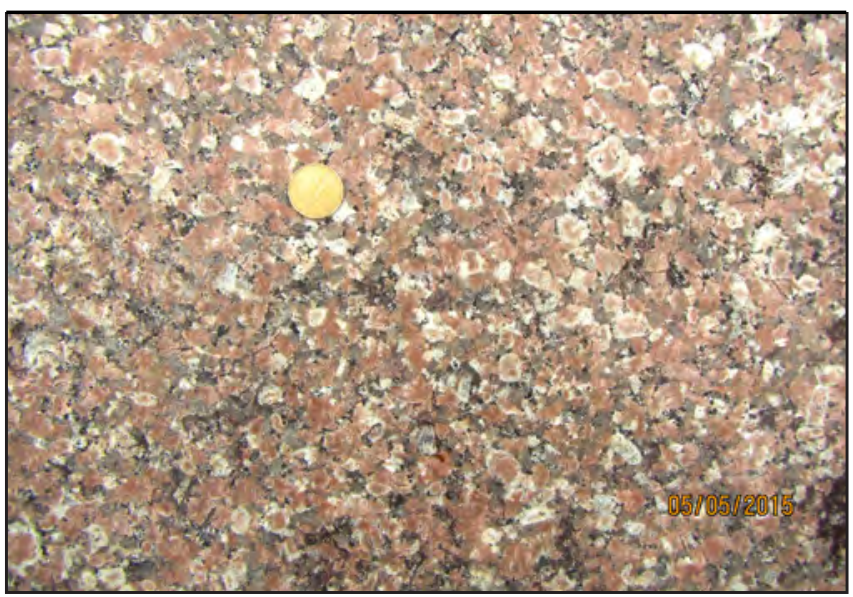

Figure 8. Mount Douglas Granite with abundant rapakivimantled alkali feldspar. Location along Lepreau Road west of Munsen Lake (see Fig. 1).

conclusion was confirmed by preliminary Late Devonian dates of $363.7 \pm 4.1 \mathrm{Ma}$ and $365.0 \pm 3.2 \mathrm{Ma}$ obtained on zircon grains from two samples taken along Red Rock Stream to the west of Red Rock Lake (geochronological data for these samples are not included herein). The location of the contact between the Mount Douglas and Utopia granites could only be limited to within a distance of $500 \mathrm{~m}$ due to the scarcity of exposures to the south of Red Rock Lake.

Detailed field mapping was conducted in the Wellington Lake-New River area (Figs. 1 and 2) to better define the contacts between the Utopia, Mount Douglas, and Jake Lee Mountain plutons. Previous mapping in this area by McLeod (1990) had delineated a one km-wide by two kmlong eastward continuation of the Utopia Granite preserved within the Mount Douglas Granite on the east side of New River. Re-examination of exposures along the resource road running south from Victoria Lake revealed the presence of conspicuous rapakivi-mantling of potassium feldspars leaving little doubt that these rocks are part of the Mount Douglas pluton. The next exposure to the south along the resource road, following a gap in exposure of $800 \mathrm{~m}$, is comprised of a medium pink, equigranular granite mapped by McLeod (1990) as part of the Mount Douglas pluton. However, the outcrop at this site lacks rapakivi texture so sample 15-87 was collected for geochronological analysis (Location 2 on Figs. 1 and 2) to determine if this granite is part of the Silurian Utopia pluton. sample 15-104 was collected to the south of Wellington Lake to confirm that the Utopia Granite extends to the west of New River as suggested by the recent mapping (Location 3 on Figs. 1 and 2).

Distinctive, medium- to coarse-grained, light greyishwhite to greyish-pink granite, underlying an area of about $15 \mathrm{~km}^{2}$ centered on Wellington Lake, was recognized during the recent mapping on west side of the New River about 19 $\mathrm{km}$ northeast of Lake Utopia (Fig. 1). Originally included as part of the Utopia Granite by McLeod (1990), its zirconiumrich geochemistry suggests that it may be a separate pluton (see geochemistry section below) and is herein referred to as the Wellington Lake Granite. It is bordered to the southeast by a narrow band of Mount Douglas Granite consisting of light pink, medium-grained granite grading into a finegrained porphyry containing rapakivi-mantled potassium feldspar. The Wellington Lake Granite is separated from the main mass of the Mount Douglas Granite to the northwest by a screen from 200 to $400 \mathrm{~m}$ wide of light grey siltstone with locally interbedded basalt assigned to the Silurian (Llandoverian to Wenlockian) Jones Creek Formation of the Mascarene Group (Fig. 2). Siltstone inclusions from 10 to $20 \mathrm{~cm}$ in diameter are common in the Wellington Lake Granite to the west of Wellington Lake near the unexposed northwestern contact with the sedimentary screen (Fig. 9). Sample 15-72 was collected at this site (Location 5 on Figs. 1 and 2) to define the age of crystallization of the Wellington Lake Granite.

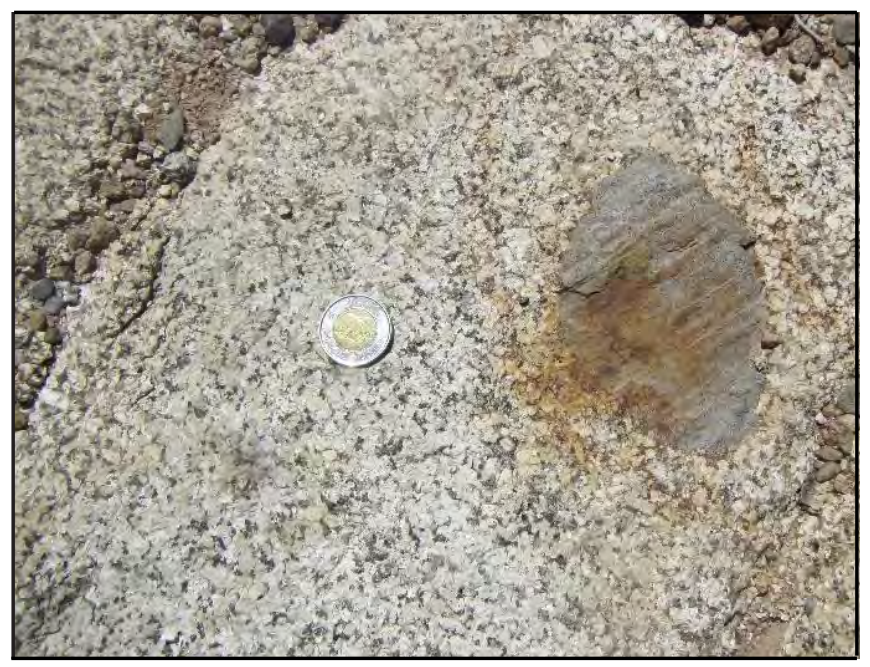

Figure 9. Greyish-white, medium-grained, equigranular granite of the Wellington Lake Granite containing light grey siltstone inclusion about $2 \mathrm{~km}$ southwest of Wellington Lake (Location 5 on Fig. 1).

The peralkaline Jake Lee Granite, named by Currie (1988), is an oblong pluton about $20 \mathrm{~km}^{2}$ in area intruded into volcanic and sedimentary rocks of the Llandoverian Letete Formation (Mascarene Group) in the southeast, Pridolian sedimentary rocks of the Eastport Formation (Mascarene Group) in the northeast, and granitic rocks of the Utopia pluton in the northwest (Fig. 2). Its core consists of medium-grained, beige, equigranular, riebeckite-bearing granite grading outward to a fine-grained, light grey to light pink, porphyritic margin locally exhibiting rapakivi texture (Fyffe 1998). The fine-grained, northern margin of the Jake Lee Mountain pluton contains abundant, angular blocks of gabbro (Fig. 10). A coherent screen of gabbroic rocks about $300 \mathrm{~m}$ wide separates it from the Utopia Granite to the north. Sample JL16-1 was collected from medium-grained, beige granite forming the core of the Jake Lee Mountain pluton in order to determine the age of this previously undated peralkaline granite (Location 4 on Figs. 1 and 2). 


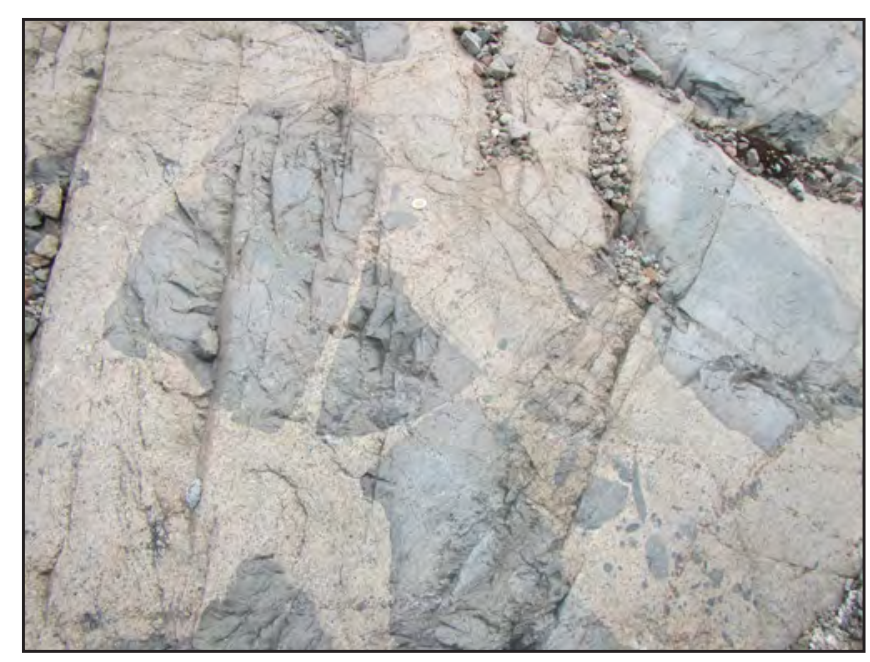

Figure 10. Angular blocks of gabbro injected by amphibole-bearing granite along the northern margin of Jake Lee Mountain pluton.

\section{LASER ABLATION ICP-MS U-Pb GEOCHRONOLOGY}

$\mathrm{U}-\mathrm{Pb}$ crystallization ages of zircon and monazite were determined by in situ laser ablation inductively coupled plasma-mass spectrometry (LA ICP-MS) at the University of New Brunswick. Standard polished thin sections were prepared and the zircon and monazite were analyzed using a Resonetics S-155-LR $193 \mathrm{~nm}$ ArF Excimer laser ablation (LA) system coupled to an Agilent 7700x quadrupole inductively coupled plasma-mass spectrometer (ICPMS). Only those zircon and monazite grains large enough to accommodate a $25 \mu \mathrm{m}$ and $17 \mu \mathrm{m}$ diameter crater, respectively are measurable using laser ablation. Masses of ${ }^{31} \mathrm{P},{ }^{89} \mathrm{Y},{ }^{202} \mathrm{Hg},{ }^{204} \mathrm{~Pb},{ }^{206} \mathrm{~Pb},{ }^{207} \mathrm{~Pb}$, and ${ }^{208} \mathrm{~Pb},{ }^{232} \mathrm{Th}$, and ${ }^{238} \mathrm{U}$ were analyzed with ${ }^{31} \mathrm{P}$ used as a guide mass and for internal standardization (assuming $\sim 13 \mathrm{wt} . \% \mathrm{P}$ in monazite) for calculating $\mathrm{Y}, \mathrm{Pb}, \mathrm{Th}$, and $\mathrm{U}$ concentrations in monazite. ${ }^{90} \mathrm{Zr}$ was used as a guide mass and internal standardization (assuming 43 wt. \% $\mathrm{Zr}$ in zircon) for calculating $\mathrm{Pb}, \mathrm{Th}$, and $\mathrm{U}$ concentrations in zircon. For monazite, $\mathrm{U}-\mathrm{Pb}$ isotope data was standardized using GSC-8153 monazite and the accuracy of the results confirmed using 44069 monazite (Aleinikoff et al. 2006). Zircon was standardized against 1099 Ma FC-1 zircon (Paces and Miller 1993) and accuracy checked using $337 \mathrm{Ma}$ Plesovice zircon (Slama et al. 2008). Concentrations of $U$ and $T h$ in zircon were calculated relative to NIST610 which was analyzed throughout the analytical sequence. The data have been reduced using the VizualAge U-Pb geochronology data reduction scheme under Iolite software v. 2.5. Common- $\mathrm{Pb}$ correction was applied using Andersen (2002) method. A total between 45 and 82 of zircon and monazite analyses were obtained for each sample; however, of this total number of analyses a subset that are $<5 \%$ discordant was used to calculate concordia ages using Isoplot version $3.71 .09 .05 .23 \mathrm{nx}$ (Ludwig 2009). Details of the method have been described in McFarlane (2015) and Azadbakht et al. (2016). The results of the $\mathrm{U}-\mathrm{Pb}$ monazite and zircon geochronological studies on the six samples selected for LA ICP-MS analysis (Table 1, Fig. 11) are discussed in detail below.

\section{Utopia Granite (sample 171-6)}

Sample 171-6 was collected on the summit of Dawson Mountain at Location 1 on Fig. 1. This light pink variety of Utopia Granite is a medium-grained, moderately altered granite with a slightly seriate texture composed of subhedral potassium feldspar, quartz, plagioclase, and biotite. Fractures and thin veins in the granite are filled with crystalline quartz. The perthitic potassium feldspar occurs as subhedral to euhedral twinned crystals up to 1.25 $\mathrm{cm}$ in diameter. Plagioclase occurs as smaller laths and is

Table 1. Summary of new U-Pb monazite and zircon concordia ages obtained by LA ICP-MS from the Saint George Batholith*.

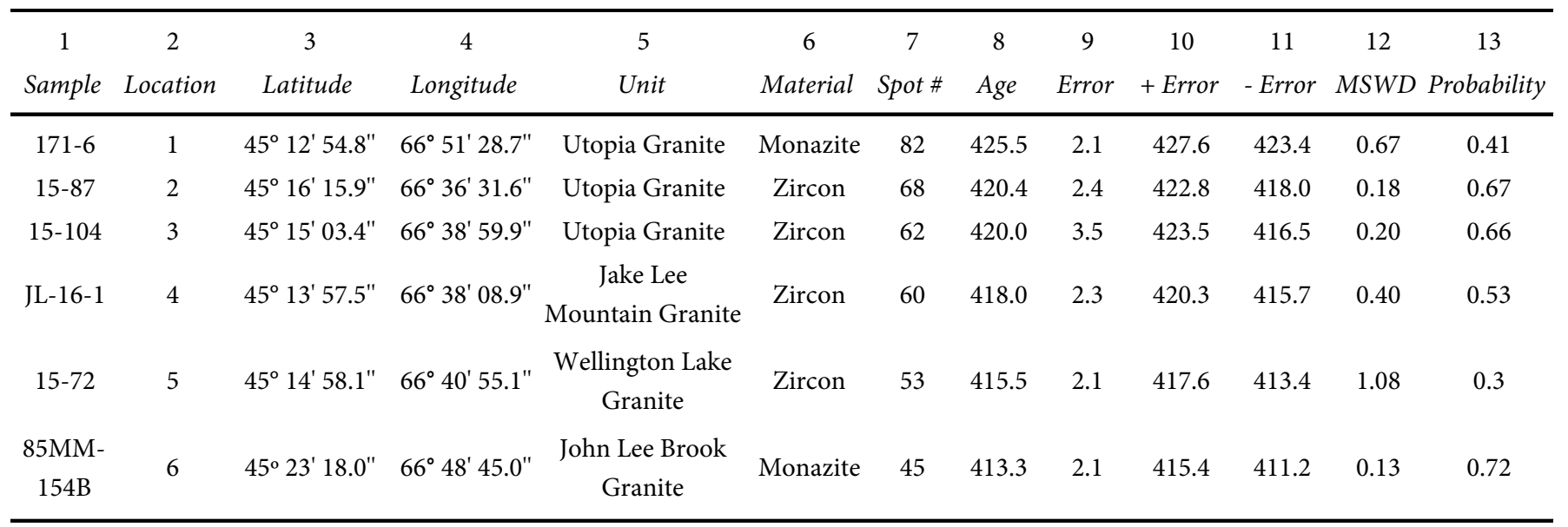

${ }^{\star}$ Note: $(2)=$ Location of the samples are shown in Figures 1 and 2. (7) = Number of analyzed spots of monazite or zircon grains; $(8)=$ Concordia ages $(\mathrm{Ma})$ of samples; $(9)=$ Error is two standard deviations; $(10)=$ Concordia ages plus the error number $(\mathrm{Ma}) ;(11)=\mathrm{Concordia}$ ages minus the error number (Ma); (12) = MSWD (Mean Squares of Weighted Deviation) of concordance; 13 = Probability of concordance. 


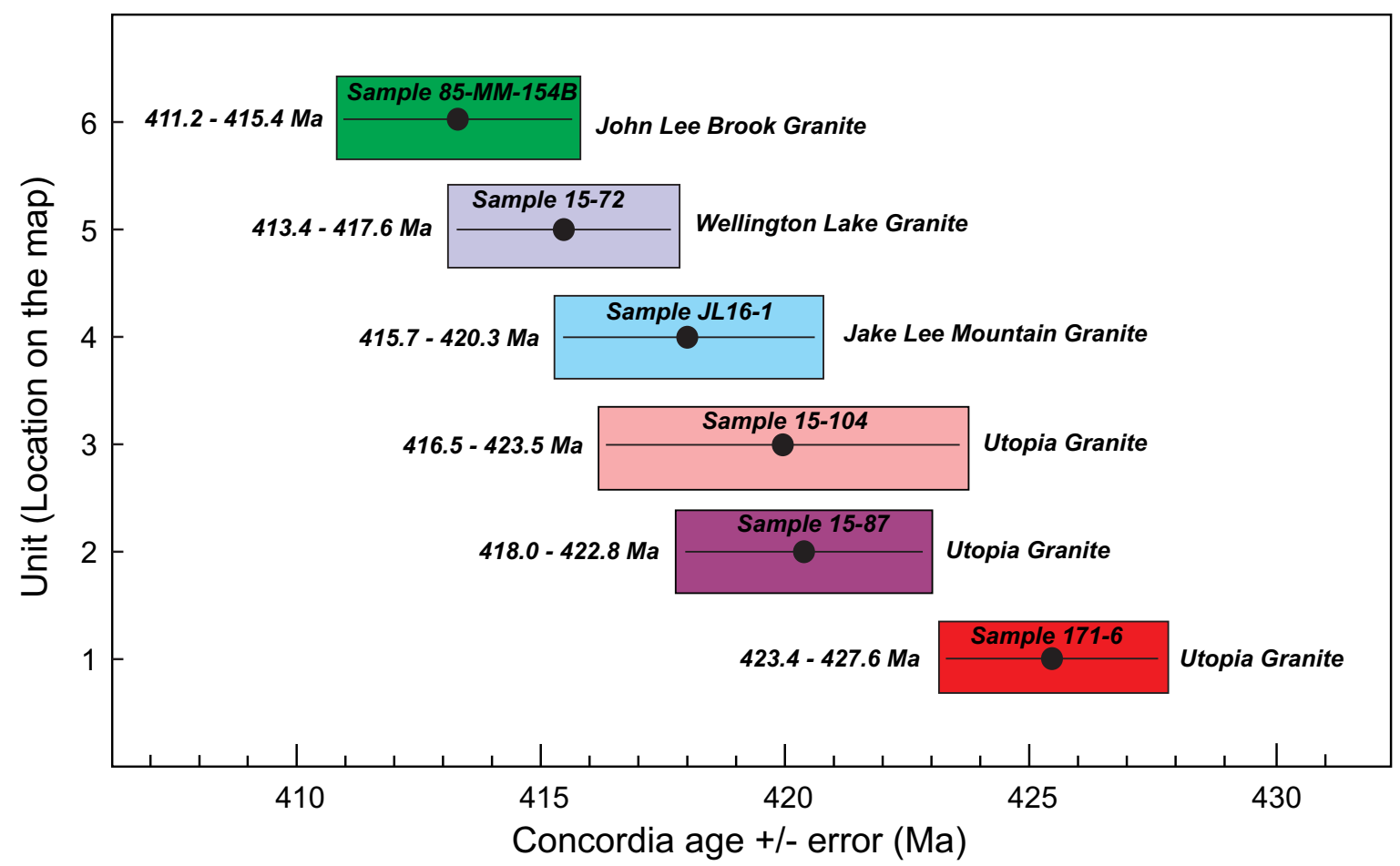

Figure 11. New U-Pb monazite and zircon geochronological results from the Saint George Batholith. Vertical axis legend is location number for dated samples shown on Figures 1 and 2. Error bars show the concordia age of each sample $\pm 2 \sigma$ (see Table 1).

moderately altered to sericite in the central parts of grains. Quartz crystals are typically rounded and have seriate boundaries with the surrounding groundmass. Biotite grains are present as tabular grains rich in opaques ( $\mathrm{Fe}-\mathrm{Ti}$ oxides), zircon, monazite, and apatite. Monazite crystals occur as subhedral to anhedral and almost rounded grains ranging from very small up to $100 \mu \mathrm{m}$ in diameter and are mostly in contact with other accessory minerals, such as Fe-Ti oxides, zircon, and apatite (Fig. 12). A total of 82 spot analyses on monazite grains were obtained for the $\mathrm{U}-\mathrm{Pb}$ geochronological study (Table A1). The results for monazite grains from the Dawson Mountain sample

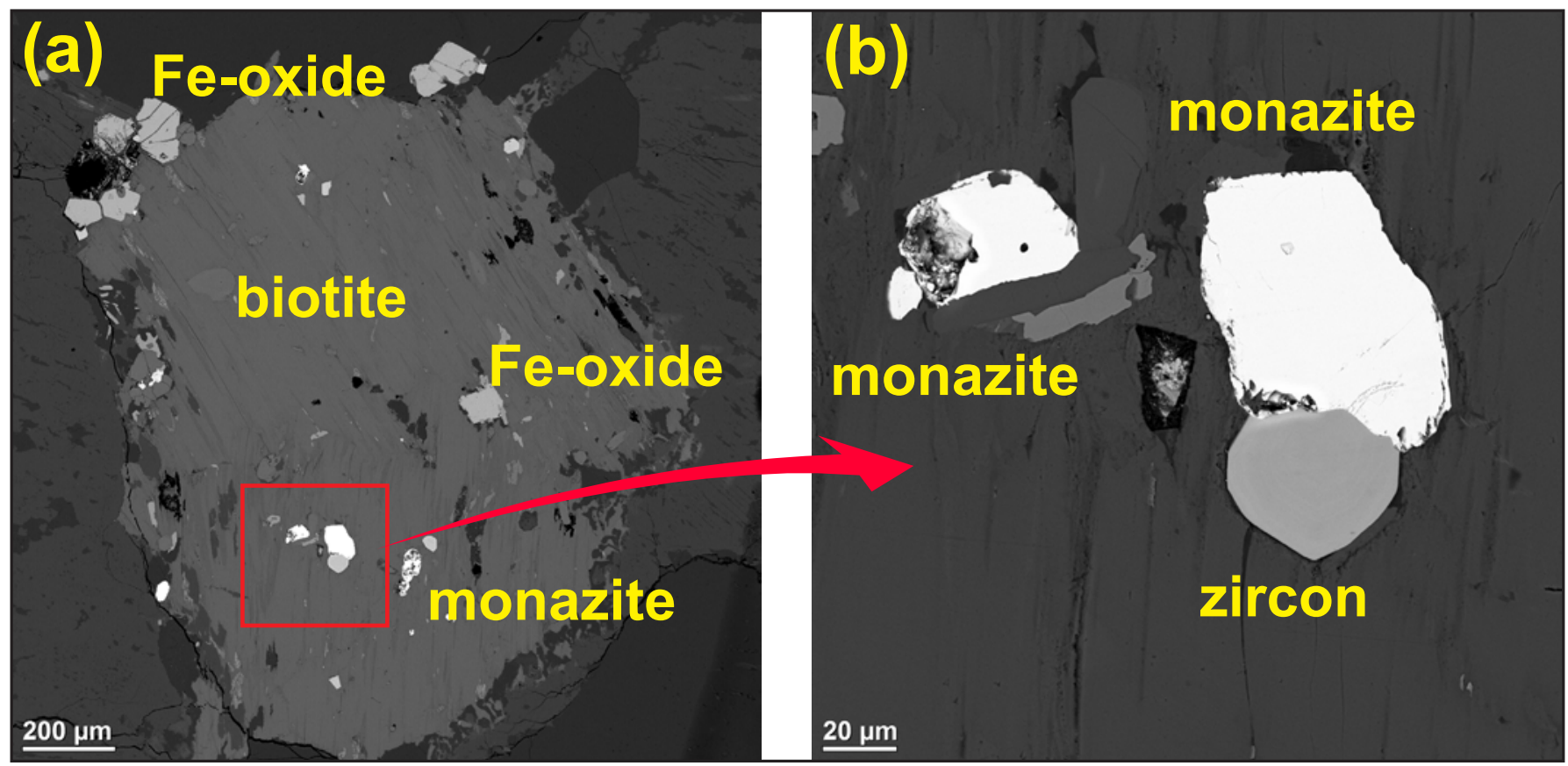

Figure 12. (a) SEM-BSE image of accessory minerals as inclusions in biotite from sample 171-6. (b) Close-up of image (a) showing homogeneous monazite grains with no internal zoning revealed by changing the gamma value (back scatter contrast) of the photograph. 
yielded a U-Pb crystallization age of $425.5 \pm 2.1 \mathrm{Ma}$ (Table 1 and Fig. 13), i.e., Ludlovian according to the time scale of Ogg et al. (2016). This age is the same within error as the previously published $\mathrm{U}-\mathrm{Pb}$ zircon age of $428.3 \pm 1.0 \mathrm{Ma}$ (latest Wenlockian) obtained on a sample of the typically red Utopia Granite exposed on Rte. 785 near the northern end of Lake Utopia (Barr et al. 2010).

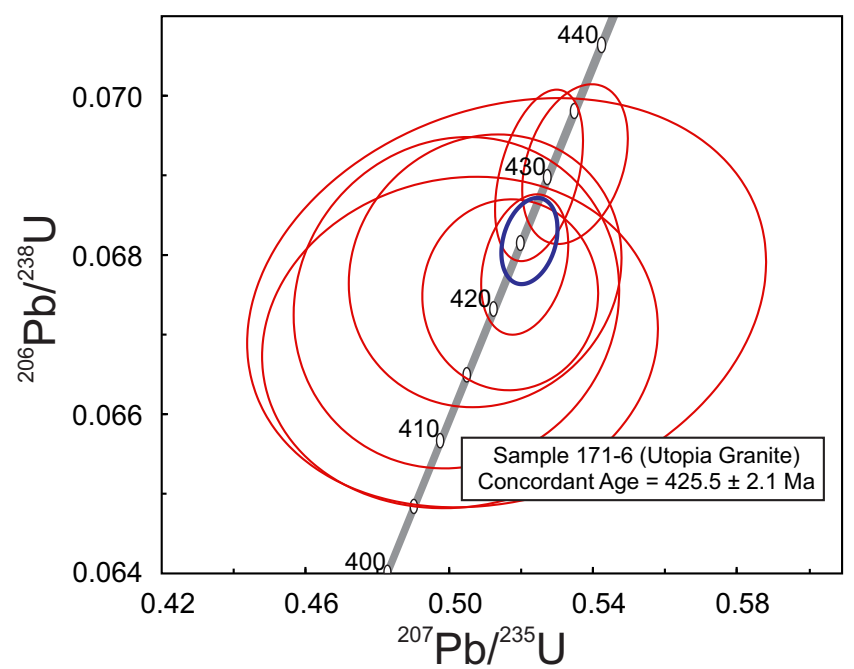

Figure 13. U-Pb concordia plot for laser ablation ICPMS analyses of monazite grains from the Sample 171-6 (Utopia Granite). Concordia age $=425.5 \pm 2.1 \mathrm{Ma}$; data point error ellipses are $2 \sigma$; MSWD of concordance $=$ 0.67 ; probability of concordance $=0.41$. The blue ellipse is weighted-mean error ellipse.

Figure 14. (a) Photomicrograph of a biotite from sample 15-87; the biotite contains inclusions of zircon and apatite surrounded by zones of radiation damage (in crosspolarized light). (b) SEM-BSE image of a zircon crystal from sample 15-87 exhibiting oscillatory zoning.
Utopia Granite (samples 15-87 and 15-104)

Sample 15-87 was collected on the east side of New River at Location 2 on Figs. 1 and 2. Previously included as part of Mount Douglas Granite (McLeod 1990), recent field observations indicate that it is textually more similar to the Utopia Granite in that rapakivi-mantling is lacking. The sample is a granular, medium-grained, pink granite composed mainly of quartz grains; perthitic potassium feldspar grains up to $0.75 \mathrm{~cm}$ in diameter, which are moderately altered to very fine-grained sericite along fractures or twinning planes; plagioclase grains that range from small inclusions hosted by potassium feldspar to moderately large subhedral-euhedral grains with a maximum diameter of $0.5 \mathrm{~cm}$ are locally altered to sericite along albite twin planes; and iron-rich biotite laths, which are altered to chlorite along cleavage planes. Zircon and apatite are the most abundant accessory minerals, mostly occurring as inclusions in biotite (Fig. 14a). The zircon crystals occur as subhedral to euhedral grains up to $100 \mu \mathrm{m}$ in diameter that mostly are in contact with other accessory minerals, such as Fe-Ti oxides, apatite, and xenotime, and exhibit oscillatory zoning (Fig. 14b). Only those zircon crystals large enough to accommodate a $25 \mu \mathrm{m}$ - diameter crater are measurable using laser ablation, and inclusionand crack-free grains are preferred for analyses. A total of 68 spot analyses of zircon grains were ablated for the $\mathrm{U}-\mathrm{Pb}$ geochronological study (Table A2). The results for zircon grains from sample 15-87 yielded a U-Pb crystallization age of $420.4 \pm 2.4 \mathrm{Ma}$ (Table 1 and Fig. 15), confirming that it is of Silurian (Pridolian) age and, therefore, part of the Utopia pluton rather than the Late Devonian Mount Douglas pluton.

A sample of medium-grained, pink, biotite granite (sample 15-104) was collected on the west side of New River at Location 3 on Figs. 1 and 2 to confirm that the Utopia Granite extends into the area south of Wellington

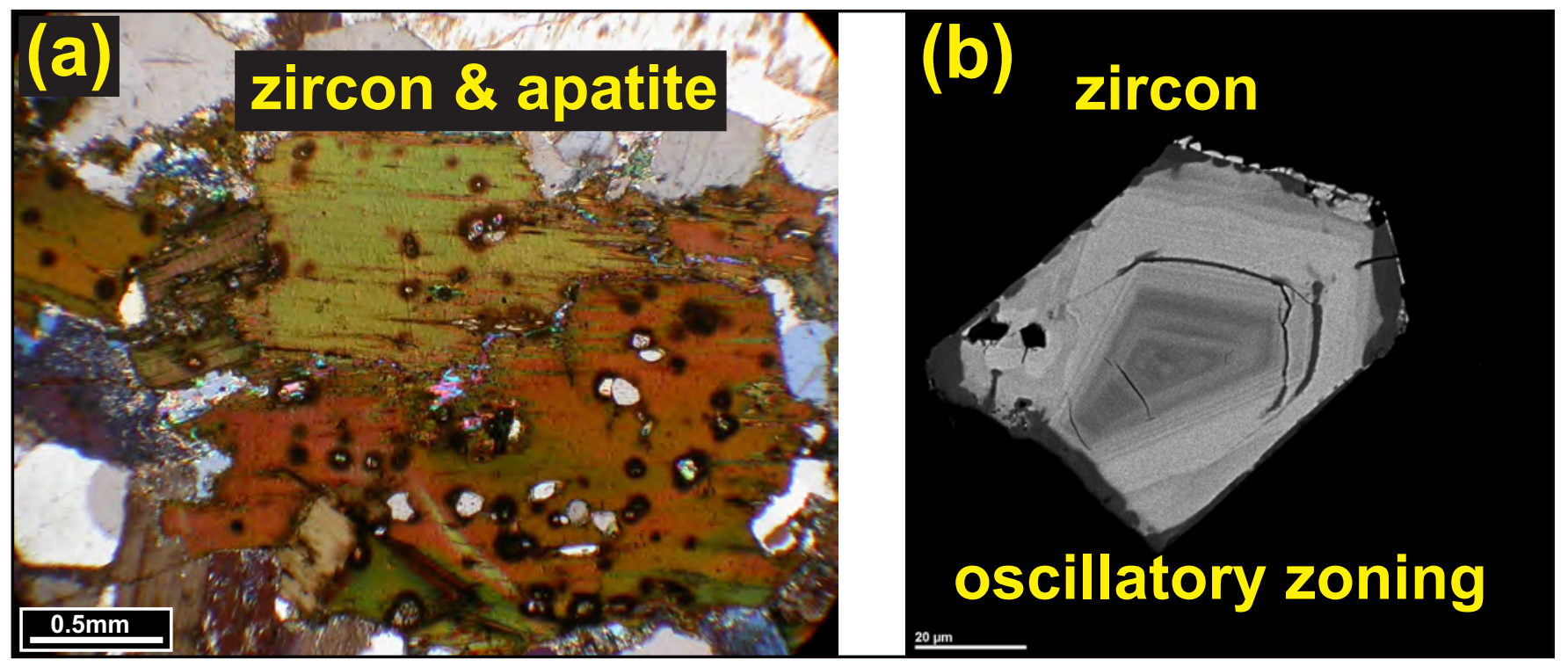




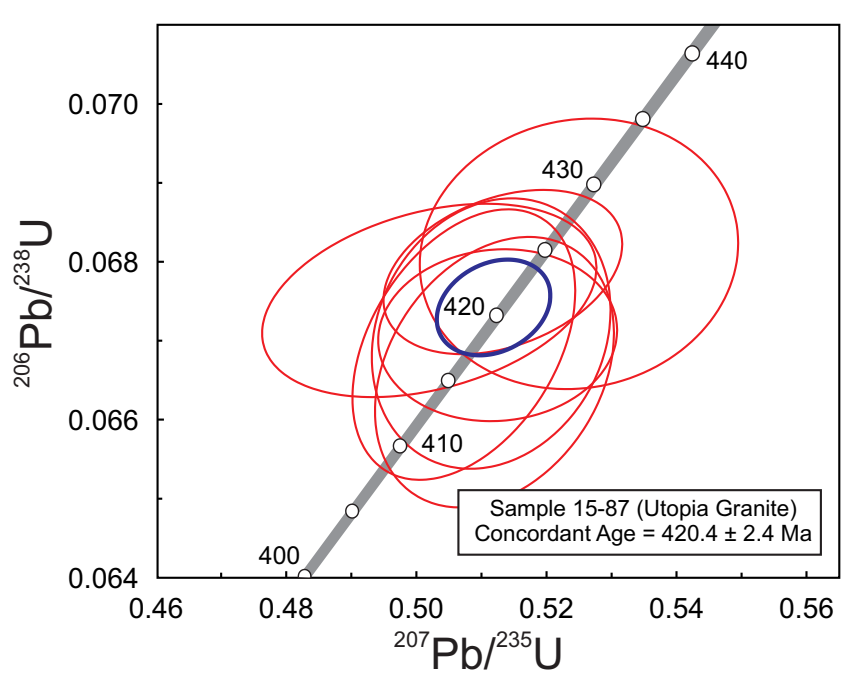

Figure 15. U-Pb concordia plot for laser ablation ICPMS analyses of zircon grains from sample 15-87 (Utopia Granite). Concordia age $=420.4 \pm 2.4 \mathrm{Ma}$; data point error ellipses are $2 \sigma$; MSWD of concordance $=0.18$; probability of concordance $=0.67$. The blue ellipse is weighted-mean error ellipse.

Lake. The exposures in this area were previously included as part of Jake Lee Mountain Granite (McLeod et al. 1998) but recent field observations indicate that amphibole is not present in these rocks. A total of 62 spot analyses of zircon grains were ablated for the $\mathrm{U}-\mathrm{Pb}$ geochronological study (Table A3). The analytical results on the zircon grains from sample 15-104 yielded a U-Pb crystallization age of 420.0 $\pm 3.5 \mathrm{Ma}$ (Table 1 and Fig. 16) essentially identical to that obtained from sample 15-87.

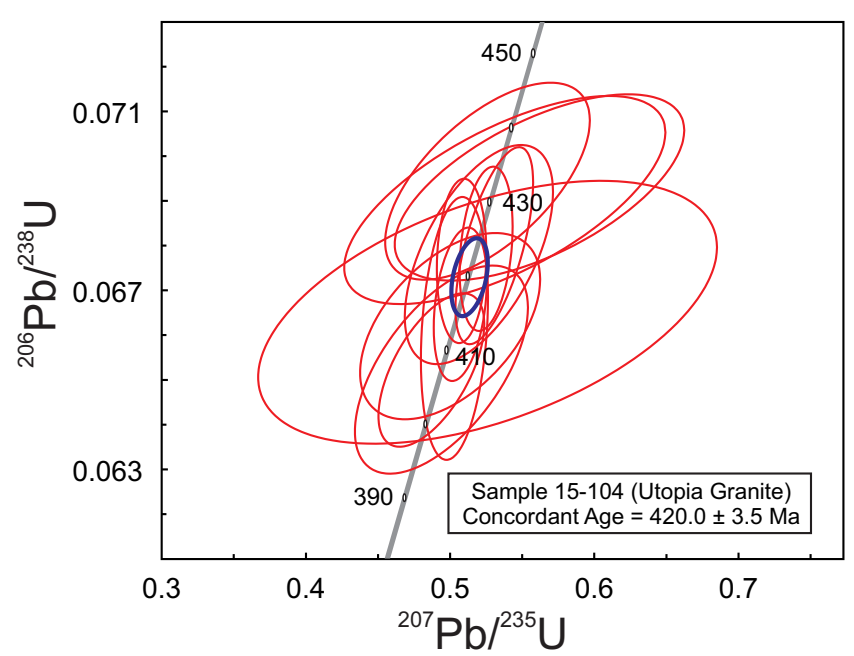

Figure 16. U-Pb concordia plot for laser ablation ICPMS analyses of zircon grains from sample 15-104 (Utopia Granite). Concordia age $=420.0 \pm 3.5 \mathrm{Ma}$; data point error ellipses are $2 \sigma ; \mathrm{MSWD}$ of concordance $=0.20$; probability of concordance $=0.66$. The blue ellipse is weighted-mean error ellipse.
Jake Lee Mountain Granite (sample JL16-1)

A sample of medium-grained, beige, equigranular, riebeckite-bearing granite (sample JL16-1) was collected along the resource road leading west off the Anthony Lake Road toward Jake Lee Mountain at Location 4 on Figs. 1 and 2. The sample is composed of quartz up to $2 \mathrm{~mm}$ in diameter, slightly altered perthitic potassium feldspar grains up to $3 \mathrm{~mm}$ in diameter, minor plagioclase with a maximum diameter of $1 \mathrm{~mm}$; and iron-rich biotite laths, which are intensely altered to Fe-Ti oxides. Quartz and alkali feldspar are locally intergrown in a granophyric texture within a mosaic of polygonal, equigranular crystals of quartz and alkali feldspar. Accessory minerals include euhedral to subhedral zircon crystals that display oscillatory zoning, Fe-Ti oxides, and monazite crystals, which are present as inclusions in zircon or as small grains near or in contact with zircon and Fe-Ti oxide grains. Fine fractures and quartz stringers are present in the specimen.

A total of 60 spot analyses of zircon grains were ablated for the U-Pb geochronological study (Table A4). The analytical results from zircon grains from sample JL161 yielded a U-Pb crystallization age of $418.0 \pm 2.3 \mathrm{Ma}$ for the core of the Jake Lee Mountain Granite (Table 1 and Fig. 17). Although this latest Pridolian to earliest Lochkovian age overlaps statistically with the ages obtained from the two samples of Utopia Granite in the New River area, it is consistent with the Jake Lee Mountain Granite being the younger pluton based on the presence of its finer grained northern margin (Fyffe 1998; Barr et al. 2010). The peralkaline Welsford Granite, dated at $422 \pm 1 \mathrm{Ma}$ (Bevier 1990), is not found in contact with the Utopia Granite whereas the undated peralkaline Parks Brook Granite is veined by the Utopia Granite.

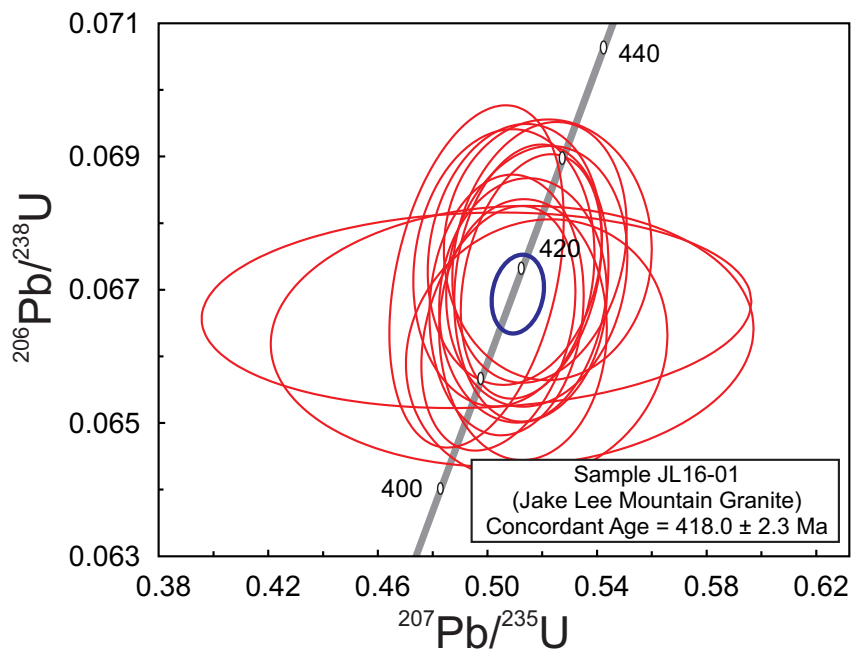

Figure 17. U-Pb concordia plot for laser ablation ICPMS analyses of zircon grains from sample JL16-01 (Jake Lee Mountain Granite). Concordia age $=418.0 \pm 2.3 \mathrm{Ma}$; data point error ellipses are $2 \sigma$; MSWD of concordance $=$ 0.40 ; probability of concordance $=0.53$. The blue ellipse is weighted-mean error ellipse. 
Wellington Lake Granite (sample 15-72)

Sample 15-72 from the Wellington Lake Granite was collected at Location 5 on Fig. 1 and 2 along a resource road running south off the Anthony Lake Road to the west of Wellington Lake. This sample is a holocrystalline, greyish pink, medium-grained, equigranular granite dominated by quartz; perthitic potassium feldspar grains, which are moderately altered to sericite; plagioclase grains, which are altered to sericite in their central parts (Fig. 18a); and biotite laths. Accessory minerals are subhedral zircon (Fig. $18 \mathrm{~b}$ ), apatite, monazite, and xenotime, which are mostly hosted by biotite; and garnet, which occurs as inclusions in plagioclase. A total of 53 spot analyses of zircon grains were ablated for the $\mathrm{U}-\mathrm{Pb}$ geochronological study. The analytical results on the zircon grains from sample 15-72 (Table A5) yielded a U-Pb crystallization age of $415.5 \pm 2.1 \mathrm{Ma}$ (Table 1 and Fig. 19). This Early Devonian (Lochkovian) age together with its unique textural characteristics (Fig. 9) and chemical composition (see below) supports the recognition of the Wellington Lake Granite as distinct from the Silurian Utopia Granite, to which it was previously assigned (McLeod 1990).

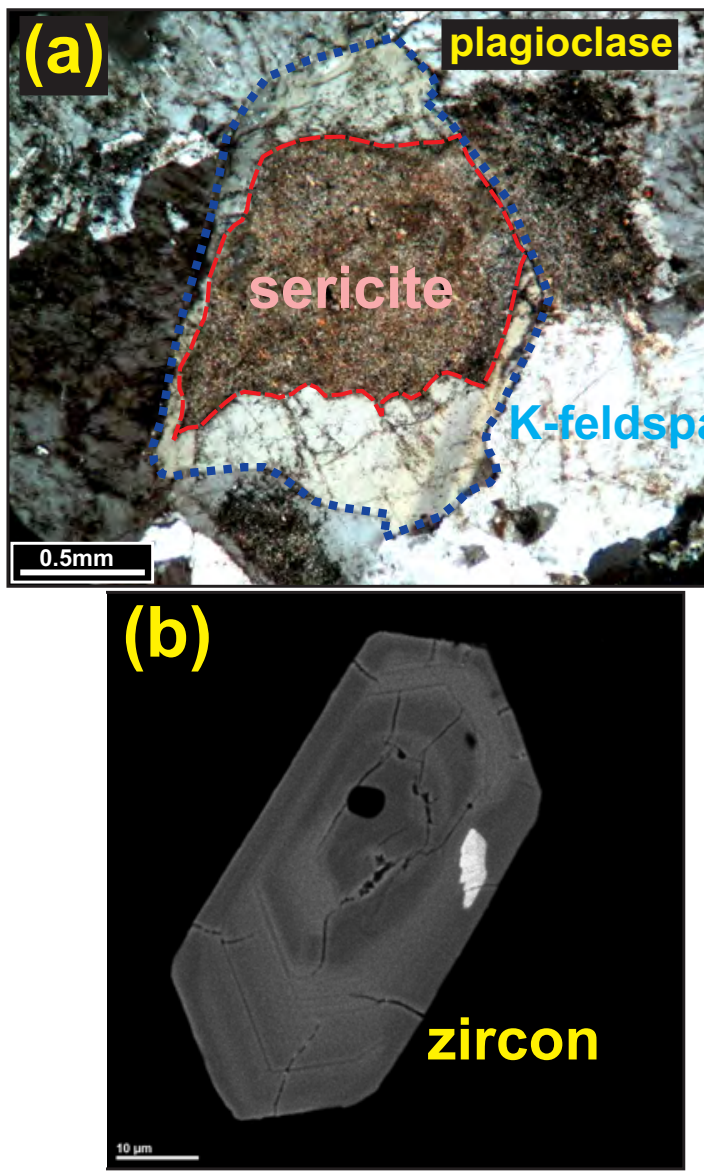

Figure 18. (a) Photomicrograph of a plagioclase grain from sample 15-72 with oscillatory zoning and selectively sericitized central part of the grain. (b) SEM-BSE image of a representative zircon crystal from sample 15-72 with oscillatory zoning.

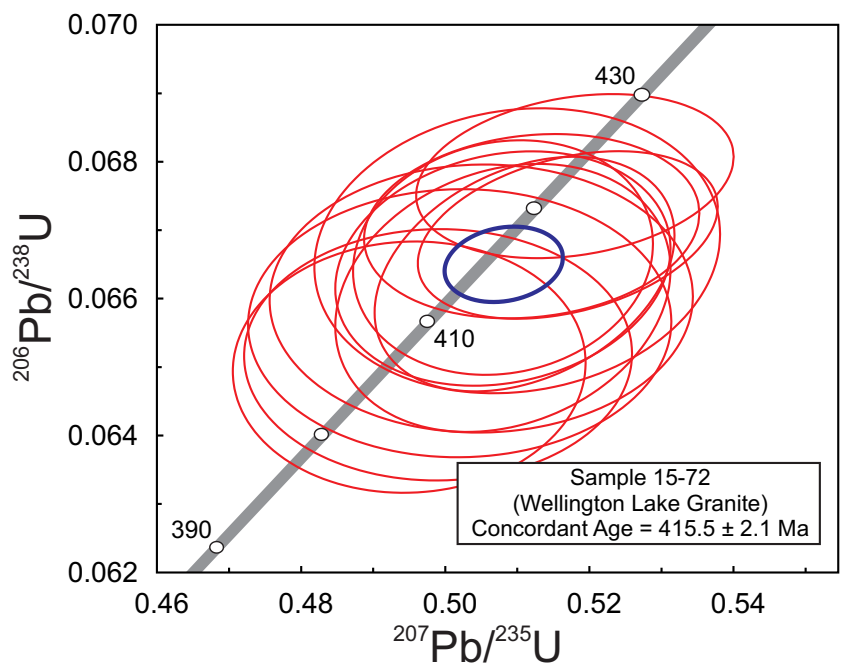

Figure 19. U-Pb concordia plot for laser ablation ICP-MS analyses of zircon grains from sample 15-72. (Wellington Lake Granite). Concordia age $=415.5 \pm 2.1 \mathrm{Ma}$; data point error ellipses are $2 \sigma$; MSWD of concordance $=$ 1.08; probability of concordance $=0.3$. The blue ellipse is weighted-mean error ellipse.

\section{John Lee Brook Granite (sample 85MM-154B)}

Sample 85MM-154B from the John Lee Brook Granite was collected by Malcolm McLeod in 1985 during his mapping of the Saint George Batholith (McLeod 1990). The sample site at Location 6 on Figs. 1 and 2 is located along a resource road about $3 \mathrm{~km}$ west of Rte. 785 near the headwaters of John Lee Brook. This white, medium-grained, equigranular, twomica granite exhibits hypidiomorphic granular texture and is composed mainly of quartz, moderately altered perthitic potassium feldspar and plagioclase, and biotite (up to 20\%), which is partially altered to chlorite. About $5 \%$ primary muscovite is present but no garnet was observed. Zircon, monazite, apatite, xenotime, and Fe-Ti oxides are accessory minerals.

Scanning electron microscope-back scattered electron (SEM-BSE) images of monazite-bearing specimens from the John Lee Brook Granite were taken using software application dPict32 (developed by Geller Microanalytical Laboratories). The abundant accessory monazite in the sample of John Lee Brook Granite occur primarily as inclusions in principal minerals, such as biotite, or in contact with other accessory minerals. To obtain a reliable age of emplacement, monazite grains showing evidence that they were crystallized from a magma and not exhibiting inherited cores need to be chosen for measurement. Thus, monazite grains that are in equilibrium with other accessory minerals, such as apatite and xenotime, were selected for geochronological studies (Figs. 20 a, b, f, and $\mathrm{h}$ ); disseminated monazite grains hosted as inclusions in biotite appear to be relatively homogeneous and reveal no inherited cores (Figs. 20c-d).

The monazite occurs as subhedral grains from 5 to 

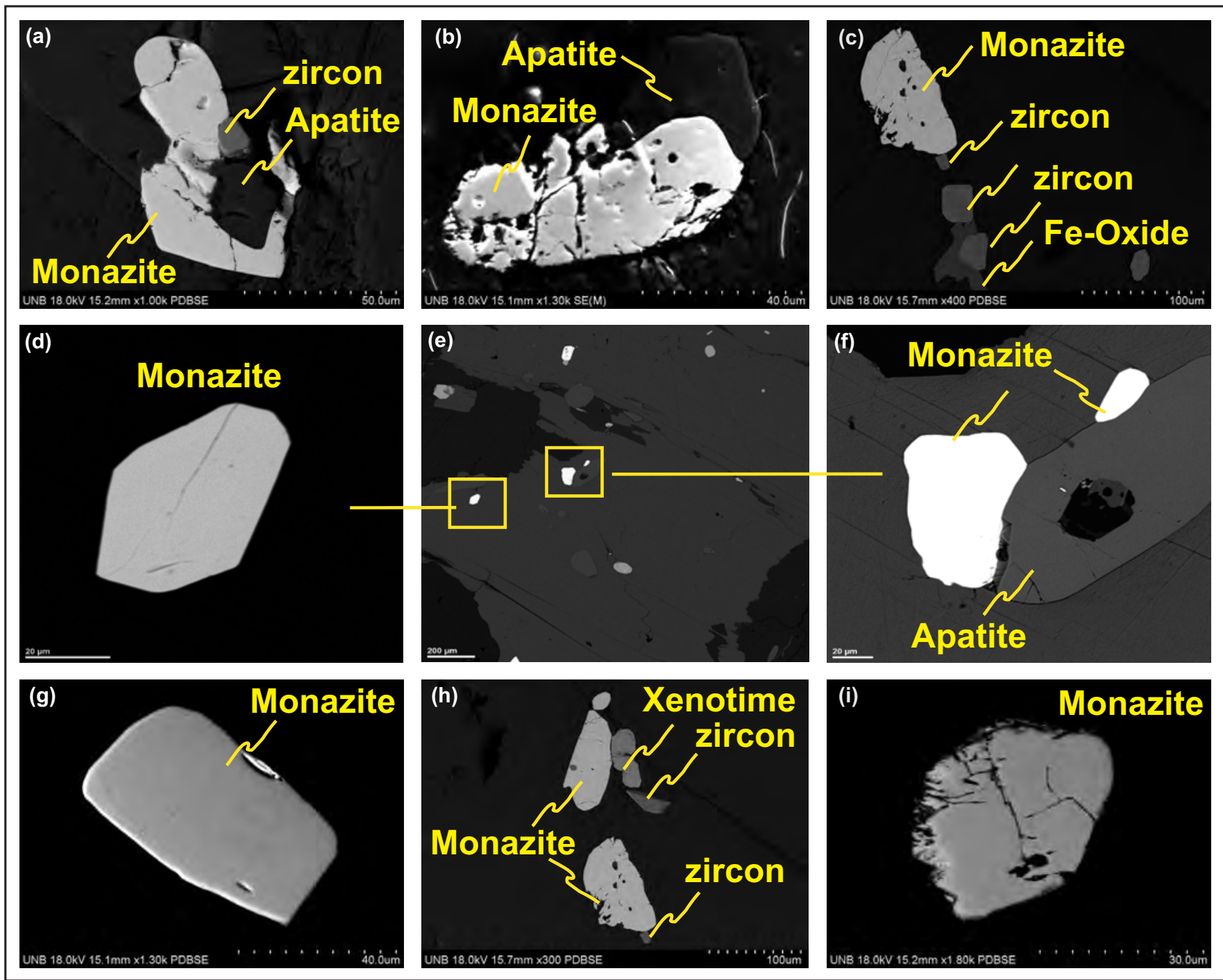

Figure 20. Representative SEM-BSE images of selected monazite grains from sample 85MM-154B. (a) Two subhedral monazite grains in equilibrium with zircon and apatite. (b) Fractured subhedral monazite that is in equilibrium with apatite. (c) Aggregate of monazite, zircon, and Fe-oxide. (d) Close-up of a fractured homogenous monazite of image (e) hosted within biotite. (e) A biotite with plenty of inclusions, including monazite, apatite, and zircon. (f) Close-up of two homogeneous monazite grains of image (e) that are in equilibrium with apatite. (g) A $60 \mu \mathrm{m} \times 40 \mu \mathrm{m}$ subhedral homogeneous monazite. (h) Monazite grains that are in equilibrium with xenotime and zircon. (i) Fractured homogeneous monazite showing no zoning.

$80 \mu \mathrm{m}$ in diameter. Only those grains large enough to accommodate a $17 \mu \mathrm{m}$ diameter crater are measurable using laser ablation. Chemical discriminants, such as $\mathrm{Y}$ vs. U/Th, and $\mathrm{P}$ vs. $\mathrm{U} / \mathrm{Th}$, indicate that the monazite is chemically homogeneous, although faint patchy zoning was locally evident in SEM-BSE images (Figs. 20b, g).

A total of 45 spot analyses of monazite grains were ablated for the U-Pb geochronological study (Table A6). The analytical results on the monazite grains from the John Lee Brook Granite yielded a crystallization age of $413.3 \pm 2.1 \mathrm{Ma}$ (Table 1 and Fig. 21). This Early Devonian (Lochkovian) age is significantly older than the previous age of $384 \pm 7 \mathrm{Ma}$ obtained by ${ }^{40} \mathrm{Ar} /{ }^{39} \mathrm{Ar}$ dating of muscovite (McLeod 1990). The contact between the John Lee Brook pluton and adjacent Magaguadavic pluton is located about
$2 \mathrm{~km}$ south of the sample site at Location 6. This site yielded both the monazite age and younger muscovite age for the John Lee Brook Granite so it is likely that the intrusion of the Magaguadavic Granite was responsible for resetting the ${ }^{40} \mathrm{Ar} /{ }^{39} \mathrm{Ar}$ isotopic system in the muscovite.

By way of contrast, ages obtained by various geochronological methods from the Magaguadavic Granite in the McDougall Lake area all fall within a relatively narrow range indicating its isotopic systems were not significantly affected by later intrusive events. A sample of megacrystic granite along Rte. 785 just east of McDougall Lake yielded a U-Pb zircon age of $396 \pm 1 \mathrm{Ma}$ (Bevier 1990) and an ${ }^{40} \mathrm{Ar} /{ }^{39} \mathrm{Ar}$ biotite age of $400 \pm 4 \mathrm{Ma}$ (McLeod 1990). A porphyritic granitic dyke along the northwestern margin of the Magaguadavic Granite at the Clarence Stream gold 


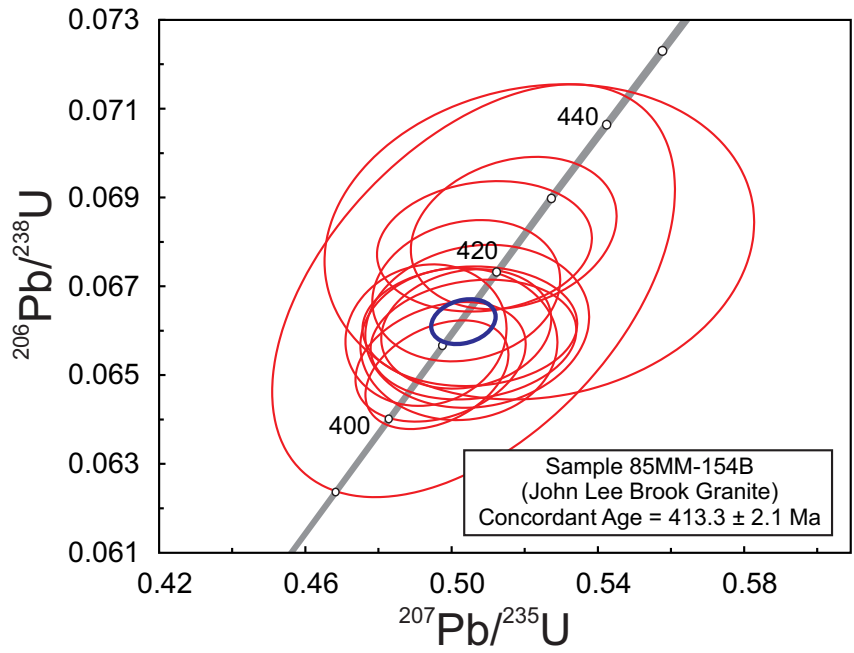

Figure 21. Concordia plot for laser ablation ICP-MS analyses of monazite grains from sample 85MM-154B (John Lee Brook Granite). Concordia age $=413.0 \pm 2.1 \mathrm{Ma}$; data point error ellipses are $2 \sigma$; MSWD of concordance $=$ 0.13 ; probability of concordance $=0.72$. The blue ellipse is weighted-mean error ellipse.

deposit (CS on Fig. 1) yielded a U-Pb monazite age of 395.5 $\pm 0.5 \mathrm{Ma}$, and a pegmatitic dyke in the same area yielded a $\mathrm{U}-\mathrm{Pb}$ monazite age of $390 \pm 8 \mathrm{Ma}$ and a $\mathrm{U}-\mathrm{Pb}$ zircon age $400 \pm 5 \mathrm{Ma}$ (Thorne et al. 2002, 2008; Davis et al. 2004).

\section{GEOCHEMISTRY}

Dated samples from the Utopia Granite (Sample 1716 and 15-87) and Wellington Lake Granite (Sample 1572) were analyzed for major elements and selected trace elements, including rare earth elements (REEs). The method used was laser ablation inductively coupled plasma-mass spectrometry (LA ICP-MS) on fused glass beads at the University of New Brunswick. Standards BCR-2, GSP-2, and SY-4 were used to check precision and accuracy on the fusion beads. Major elements were obtained with a JEOL JSM 6400 Scanning Electron Microscope equipped with an EDAX Genesis X-ray microanalysis system (SEM-EDS). The accelerating voltage was $15 \mathrm{kV}$ and the probe current was approximately $1.5 \mathrm{nA}$. Spectra were collected for 50 $s$ live-time. Trace element analyses were performed using LA-ICP-MS with a $45 \mu \mathrm{m}$ diameter crater. Standards used were NIST-610 (primary concentration standard), NIST612 (secondary concentration standard), and BCR-2G (QC standard). The geochemical results are shown in Table 2 together with data on the John Lee Brook Granite (sample 85MM-154B) taken from McLeod (1990). No analysis is available for the dated Jake Lee Mountain Granite (sample J16-1).
Table 2. LA-ICP-MS analyses of selected granites from the Saint George Batholith.

\begin{tabular}{|c|c|c|c|c|}
\hline Pluton & $\begin{array}{c}\text { John Lee Brook } \\
\text { Granite }\end{array}$ & $\begin{array}{l}\text { Wellington } \\
\text { Lake Granite }\end{array}$ & $\begin{array}{l}\text { Utopia } \\
\text { Granite }\end{array}$ & $\begin{array}{l}\text { Utopia } \\
\text { Granite }\end{array}$ \\
\hline Sample & $85 \mathrm{MM}-154 \mathrm{~B}$ & $15-72$ & $15-87$ & $171-6$ \\
\hline $\mathrm{SiO}_{2}$ (wt. \%) & 74.9 & 70.3 & 77.26 & 71.66 \\
\hline $\mathrm{TiO}_{2}$ & 0.09 & 0.32 & 0.08 & 0.57 \\
\hline $\mathrm{Al}_{2} \mathrm{O}_{3}$ & 13.97 & 16.2 & 12.92 & 14.13 \\
\hline $\mathrm{FeO}$ & 1.09 & 2.62 & 1.43 & 2.16 \\
\hline $\mathrm{MnO}$ & 0.05 & 0.06 & 0.04 & 0.81 \\
\hline $\mathrm{MgO}$ & 0.23 & 0.27 & 0.08 & 0.36 \\
\hline $\mathrm{CaO}$ & 0.5 & 0.94 & 0.34 & 0.83 \\
\hline $\mathrm{Na}_{2} \mathrm{O}$ & 4.1 & 3.41 & 2.92 & 3.63 \\
\hline $\mathrm{K}_{2} \mathrm{O}$ & 4.78 & 5.57 & 4.78 & 5.07 \\
\hline $\mathrm{P}_{2} \mathrm{O}_{5}$ & 0.03 & 0.1 & 0.05 & 0.05 \\
\hline Total & 100.04 & 99.7 & 99.85 & 99.22 \\
\hline $\mathrm{Rb}(\mathrm{ppm})$ & 247 & 132.1 & 201.2 & 223.2 \\
\hline Cs & 7.3 & 2.9 & 6 & 7.2 \\
\hline $\mathrm{Ba}$ & 132 & 119.1 & 23.1 & 167 \\
\hline $\mathrm{Sr}$ & 43 & 34.2 & 18.5 & 40.1 \\
\hline $\mathrm{Ga}$ & - & 19.8 & 20.8 & 20.6 \\
\hline $\mathrm{Ge}$ & - & 1.5 & 1.9 & 3.6 \\
\hline $\mathrm{Ta}$ & 1.9 & 1.6 & 2.2 & 2.3 \\
\hline $\mathrm{Nb}$ & 11 & 33.9 & 22.4 & 25.5 \\
\hline $\mathrm{Hf}$ & 3.2 & 16.1 & 1.5 & 7.9 \\
\hline $\mathrm{Zr}$ & 83 & 473.5 & 44 & 240.8 \\
\hline Y & 33 & 118.1 & 29.6 & 53 \\
\hline $\mathrm{La}$ & 21 & 101.5 & 11.1 & 50.5 \\
\hline $\mathrm{Ce}$ & 49 & 222.5 & 24.9 & 98.4 \\
\hline $\operatorname{Pr}$ & - & 24.5 & 2.9 & 10.5 \\
\hline $\mathrm{Nd}$ & 17 & 95.4 & 11.9 & 38.8 \\
\hline $\mathrm{Sm}$ & 3.8 & 22.9 & 2.5 & 8.9 \\
\hline $\mathrm{Eu}$ & 0.4 & 0.4 & 0.02 & 0.5 \\
\hline Gd & - & 20.6 & 3.3 & 7.7 \\
\hline $\mathrm{Tb}$ & 0.8 & 3.5 & 0.7 & 1.5 \\
\hline Dy & 4.4 & 21.5 & 4.3 & 9.2 \\
\hline Ho & - & 4.4 & 1 & 1.8 \\
\hline Er & - & 12 & 2.8 & 5.3 \\
\hline $\mathrm{Tm}$ & 0.3 & 1.6 & 0.5 & 0.8 \\
\hline $\mathrm{Yb}$ & 2.3 & 9.4 & 3.5 & 6.2 \\
\hline $\mathrm{Lu}$ & 0.4 & 1.4 & 0.6 & 0.9 \\
\hline $\mathrm{Ni}$ & 0 & 6.3 & 5.1 & 3.2 \\
\hline Co & 1.1 & 1.7 & 0.6 & 1.7 \\
\hline $\mathrm{Sc}$ & 3.4 & 19.5 & 8.4 & 9 \\
\hline $\mathrm{Cu}$ & 2 & 6.5 & 16.5 & 13.6 \\
\hline $\mathrm{Pb}$ & 10 & 2.9 & 12.5 & 57.1 \\
\hline $\mathrm{Zn}$ & 47 & 9.4 & 21.03 & 27 \\
\hline
\end{tabular}




\section{Major element characteristics}

Sample 15-72 from the Wellington Lake Granite has the lowest silica content (70.3 wt.\%) followed by sample 171-6 from the less evolved Utopia Granite (71.7 wt. \%), sample 85MM-154B from the John Lee Brook Granite (74.9 wt.\%), and sample 15-87 from the more evolved Utopia Granite (77.3 wt.\%). All four of the dated samples fall in the peraluminous field (Fig. 22a) and are characterized by high $\left(\mathrm{Fe}_{2} \mathrm{O}_{3}+\mathrm{FeO}\right) / \mathrm{MgO}$ ratio (ranging from 4.7 to 17.9), alkalis with $\mathrm{K}_{2} \mathrm{O} / \mathrm{Na}_{2} \mathrm{O}>1$, and low $\mathrm{CaO}, \mathrm{P}_{2} \mathrm{O}_{5}, \mathrm{TiO}_{2}$, and $\mathrm{MgO}$ (Table 2). On the plot of $\mathrm{SiO}_{2}$ versus $\mathrm{K}_{2} \mathrm{O}$ (Fig. 22b), samples from the John Lee Brook and Utopia granites plot in the fields of high-K; whereas the sample from the Wellington Lake Granite is associated with the shoshonite series.

\section{Trace and rare earth element characteristics}

Geochemical data presented by McLeod (1990) and Whalen (1993) indicate that the granite dated on Dawson Mountain and that dated by Barr et al. (2010) on the northern end of Lake Utopia, both of which have yielded Ludlovian ages of emplacement, are less evolved than the granite dated as Pridolian to the east of New River (Sample 15-87). McLeod's and Whalen's data also indicate that granite similar in composition to that east of New River also exists in the southern part of the Lake Utopia area to the east of Lily Lake (Fig. 1), suggesting that the Utopia Granite is a composite pluton composed of an older less evolved component (ave. $\mathrm{SiO}_{2}=73.6 \mathrm{wt} . \%, \mathrm{n}=6$ ), and a younger more evolved component (ave. $\mathrm{SiO}_{2}=76.8$ wt. \%, $\mathrm{n}=4$ ). A conspicuous magnetic lineament, located about $1 \mathrm{~km}$ north of Lily Lake, trends eastward to Lake Utopia and may represent the boundary between these two components in the western part of the Utopia pluton.

Differences between spider diagrams of the three plutons are highlighted by the contrasting REE patterns of each pluton (Fig. 23a). The REE profiles of the Utopia and Wellington Lake samples are relatively flat with gentle negative slopes. The highly evolved Utopia Granite from east of New River (sample 15-87) has the largest negative $\mathrm{Eu}$ anomaly $\left(\mathrm{Eu} / \mathrm{Eu}^{*}=0.02\right)$, the lowest normalized light $(\mathrm{LREE})$ to heavy $(\mathrm{HREE})$ rare earth ratio $\left[(\mathrm{La} / \mathrm{Yb})_{\mathrm{N}}=2.3\right]$, and most pronounced negative $\mathrm{Ba}, \mathrm{Sr}$, and Ti anomalies (Fig. 23b). Sample 15-87 also has lower overall REE abundances reflecting possible fractionation of zircon/xenotime, and monazite/apatite, which have high partition coefficients for HREE and LREE, respectively, and are abundant in this sample. The relatively high negative slope of sample 85MM$154 \mathrm{~B}\left[(\mathrm{La} / \mathrm{Yb})_{\mathrm{N}}=6.5\right]$ from the John Lee Brook Granite (Fig. 23a) is possibly the result of the presence of refractory garnet in the source area or of late-stage fractionation of garnet, which has a high partition coefficient for HREE and is abundant as inclusions mostly hosted by plagioclase in this sample. The prominent negative $\mathrm{Nb}$ and $\mathrm{Ti}$ anomalies
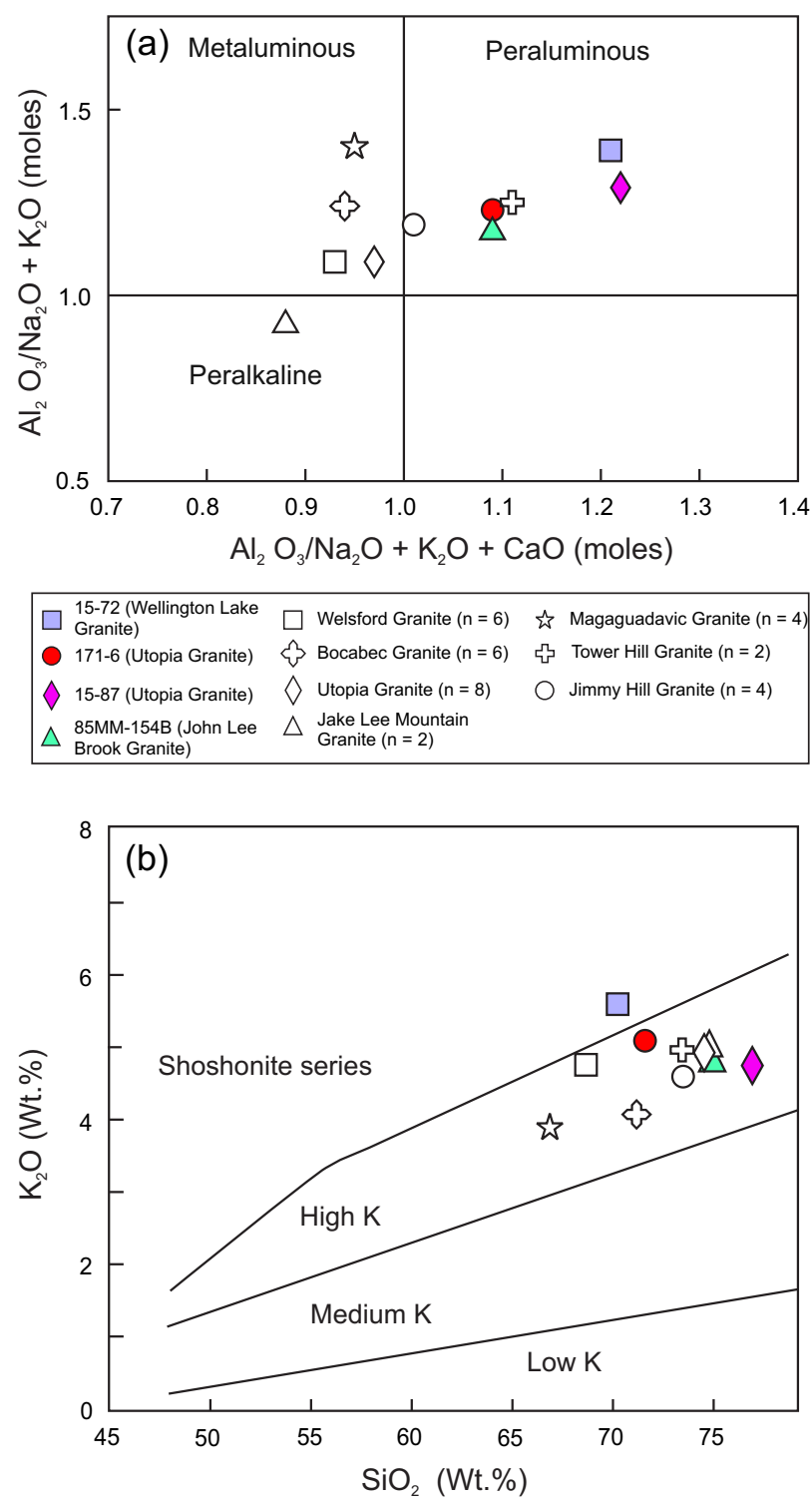

Figure 22. Major element characteristics of granite samples from the Saint George Batholith and satellite Tower Hill pluton. (a) Alumina saturation diagram. fields after Shand (1943); (b) $\mathrm{SiO}_{2}$ vs. $\mathrm{K}_{2} \mathrm{O}$ diagram; fields after Le Maitre et al. (1989). Black non-filled symbols are averaged analyses of plutons from Whalen (1993). Green-filled triangle symbol is analysis of dated John Lee Brook sample from McLeod (1990), and green nonfilled circle is averaged analyses of Jimmy Hill pluton from McLeod (1990).

exhibited by the John Lee Granite on the HFSE/primitive mantle spider diagram (Fig. 23b) are likely an inherited signature derived from melting of old granitic basement or arc-derived clastic sedimentary rocks in the source region at $413 \mathrm{Ma}$.

Sample 15-72 from the Wellington Lake Granite contains the highest overall REE abundances, exhibits the highest normalized LREE enriched pattern $\left[(\mathrm{La} / \mathrm{Yb})_{\mathrm{N}}=7.73\right]$ that is accompanied by a relatively small negative Eu anomalies 
$\left(\mathrm{Eu} / \mathrm{Eu}^{*}=0.06\right)$, likely reflecting fractionation in a more oxidized magmatic system where more of the Eu is present as $\mathrm{Eu}^{+3}$ and hence would not be incorporated into the crystallizing plagioclase (e.g., Sisson and Grove 1993).

On ' $\mathrm{Rb}$ vs $\mathrm{Y}$ + $\mathrm{Nb}$, ' $\mathrm{Rb}$ vs $\mathrm{Yb}+\mathrm{Ta}$, ' $\mathrm{Nb}$ vs $\mathrm{Y}$ ', and'Ta vs Yb' tectonomagmatic discrimination diagrams (Fig. 24), the dated samples from the Utopia and Wellington Lake granites plot in the within-plate, 'A-type' field whereas the John Lee Brook Granite falls mainly within the syn-

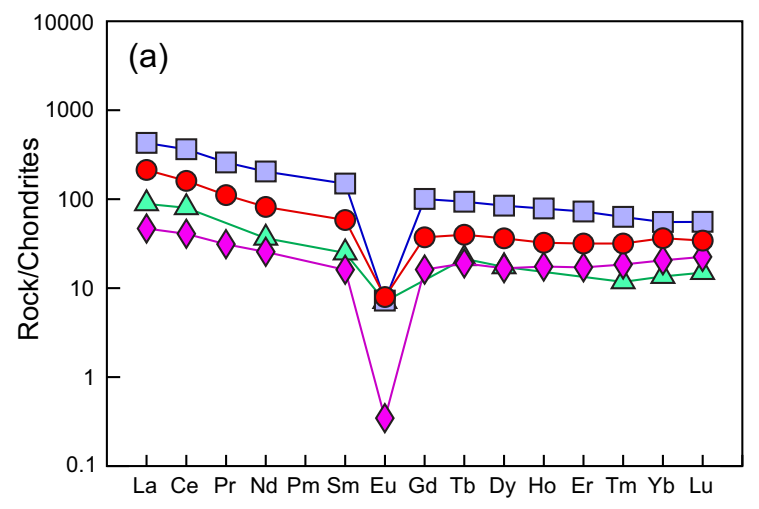

collisional, 'S-type' field. On the $\mathrm{FeO}^{*} \mathrm{vs} \mathrm{Zr}+\mathrm{Nb}+\mathrm{Ce}+$ $\mathrm{Y}$ discrimination diagram, the Utopia and Wellington Lake samples again fall in the 'A-type' field (Fig. 25a), whereas the John Lee Brook sample plots in the fractionated granite field (FG). On the ternary Y-Nb-Ce discrimination diagram (Fig. 25b), the dated samples all fall in the crustal 'A-type' field, although the strongly fractionated Utopia Granite sample from east of New River plots toward a 'mantle-type' granite.

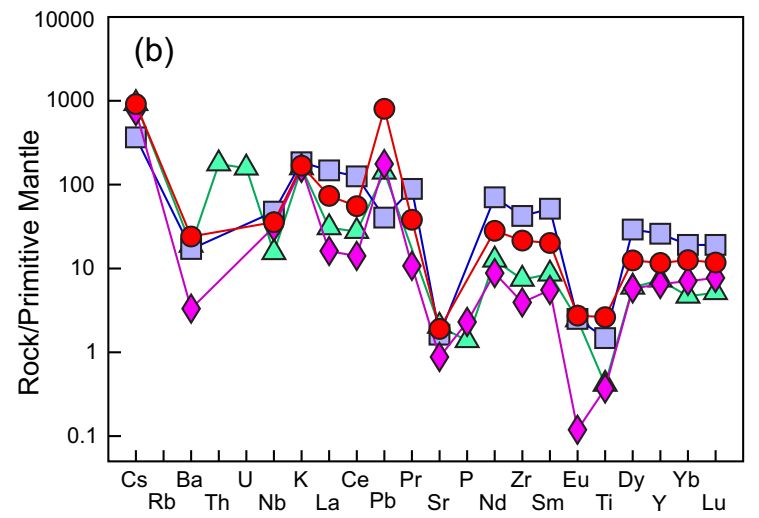

Figure 23. Trace- and rare-earth element characteristics of dated granite samples from the Saint George Batholith: (a) Chondrite-normalized REE profiles; normalizing values for C1 chondrite from Sun and McDonough (1989). (b) Primitive mantle-normalized spider diagram; primitive mantle values from Sun and McDonough (1989). See Figure 22 for symbols.
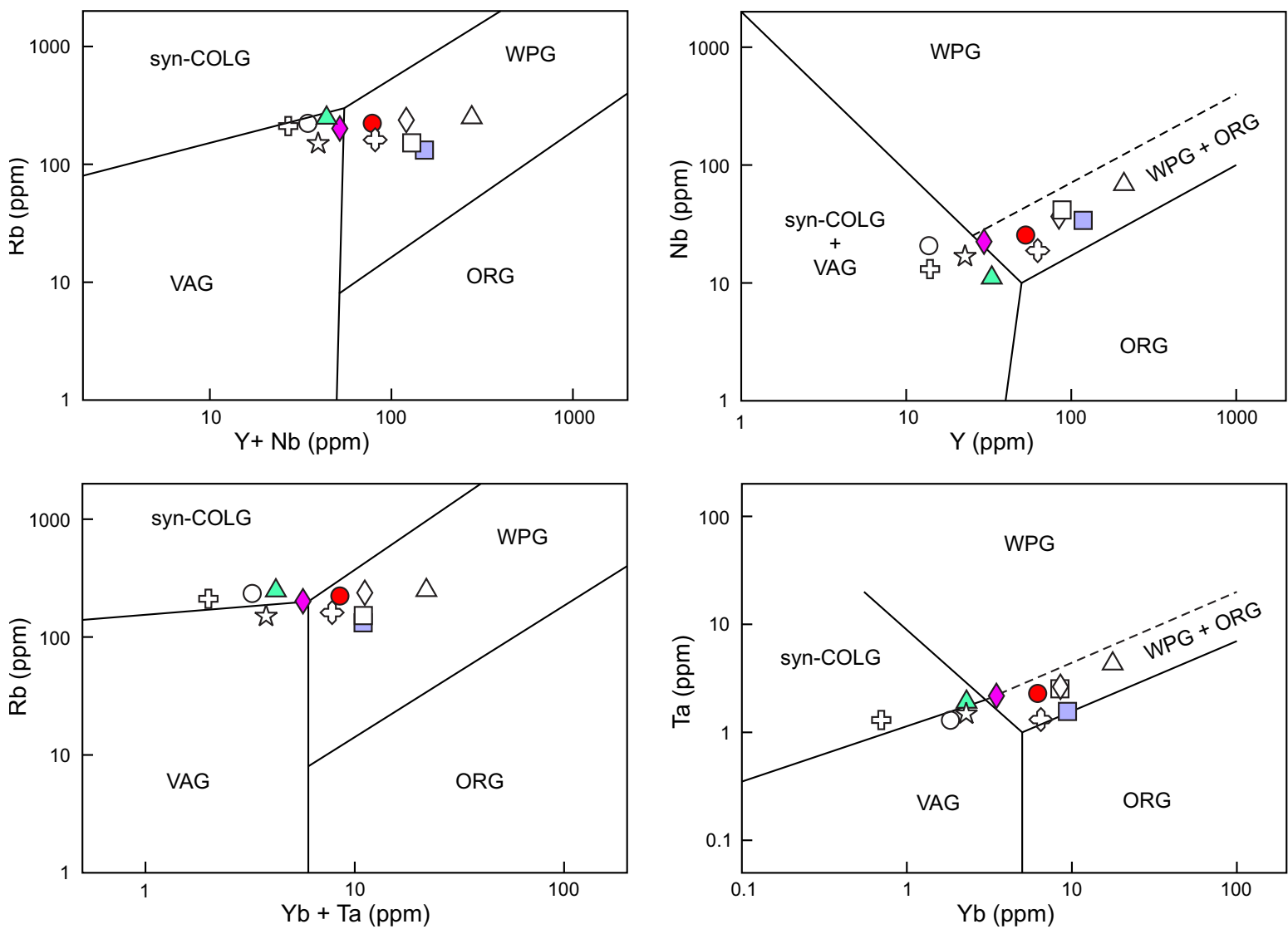

Figure 24. Tectonomagmatic discrimination diagrams for plutons of the Saint George Batholith and for the satellite Tower Hill pluton. Volcanic arc granite (VAG), syn-collisional granite (syn-COLG), within-plate granite (WPG), and ocean-ridge granite (ORG) fields after Pearce et al. (1984). Christiansen and Keith (1996) equated the VAG, syn-COLG, and WPG fields with I-, S-, and A-type granites, respectively. See Figure 22 for symbols. 

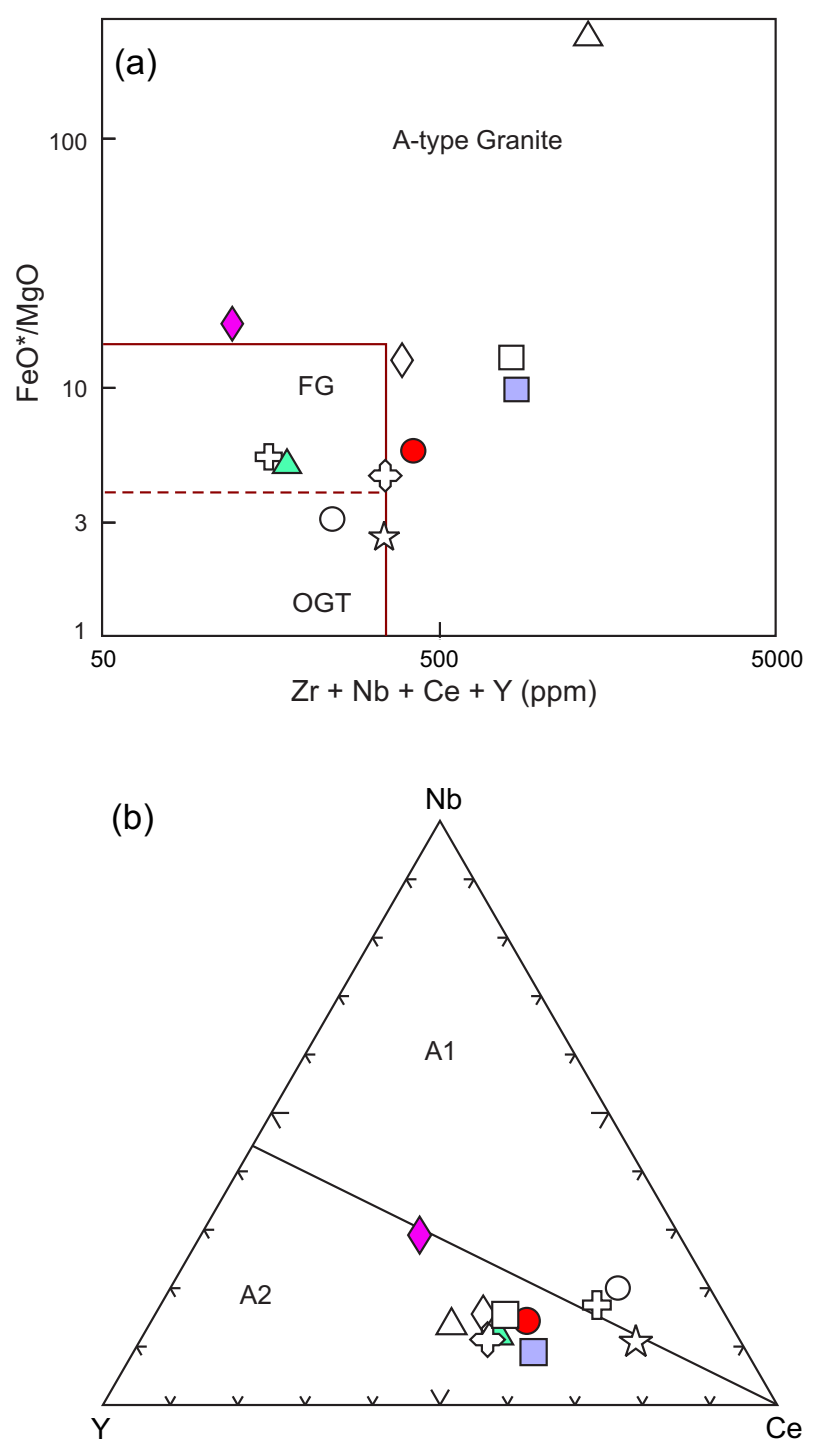

Figure 25. Tectonomagmatic discrimination diagrams for plutons of the Saint George Batholith and for the satellite Tower Hill pluton (a) $\mathrm{Zr}+\mathrm{Nb}+\mathrm{Ce}+\mathrm{Y}$ vs. $\mathrm{FeO}^{\star} /$ $\mathrm{MgO}$; fields after Whalen et al. (1987); FG = fractionated felsic granites; OGT = unfractionated M-, I-, and S-type granites. (b) Ternary Y-Nb-Ce diagram; fields after Eby (1992); A1 granites are characterized by element ratios similar to the mantle, whereas A2 granites originated from continental crust or arcs. See Figure 22 for symbols.

\section{TECTONIC EVOLUTION OF THE MASCARENE BACKARC BASIN}

The current plate tectonic model developed for the postPenobscottian evolution of southern New Brunswick relates Acadian (late Silurian to early Devonian) tectonism in the region to closure of a remnant oceanic tract, referred to as the Acadian Seaway (van Staal et al. 1996; Fyffe et al. 1999; Barr et al. 2002; White et al. 2006; van Staal et al. 2009). This seaway separated the peri-Gondwanan microcontinent of Avalonia (see inset on Fig. 1) from the amalgamated terranes already accreted to the Laurentian continental margin during Early Paleozoic closure of the Iapetus Ocean. The peri-Gondwanan microcontinent of Ganderia, the most outboard of these Iapetan terranes, was accreted to the Laurentian margin during Salinic (late Ordovician to late Silurian) orogenesis. Precambrian rocks of the New River and Brookville belts are considered to underlie the sparsely preserved platform of Ganderia, whereas the Cambrian-Ordovician sedimentary rocks of the St. Croix belt are interpreted to represent its Paleozoic passive margin (van Staal et al. 1996; Fyffe et al. 2011). Subsequent Acadian tectonism and magmatism in southwestern New Brunswick is attributable to accretionary events associated with closure of the Acadian Seaway by northwest-directed subduction beneath the Kingston arc-Mascarene backarc system and its St. Croix-New River substrate (Fig. 1). The arc-backarc system was subsequently extensively dismembered by strike-slip displacement along the Sawyer Brook, St. George, Wheaton Brook, Belleisle, and Kennebecasis faults (Stewart et al. 1995; Fyffe et al. 1999, Fyffe et al. 2011). The Sawyer Brook, St. George, and Wheaton Brook faults were inactive by the Late Devonian as they are cross-cut by the Mount Douglas Granite, emplaced between $367 \pm 1$ and $366 \pm 1$ Ma (Bevier 1989; McLeod 1990).

The Mascarene backarc basin is situated along the transitional zone between the Ganderian platform comprised of Neoproterozoic basement rocks and its thin cover of Cambrian quartzite (New River belt) in the south and the Ganderian passive margin comprised of a thick succession of Cambrian-Ordovician sedimentary rocks (St. Croix belt) in the north (Fyffe et al. 2011). The Silurian sequences in the dismembered backarc basin, which are all included in the Mascarene Group, have been divided into several formations (i.e., Oak Bay, Waweig, Letete, Long Reach, Jones Creek, and Eastport), described briefly below. The contact between the steeply dipping conglomerate of the Silurian Oak Bay Formation at the base of the Mascarene Group and Cambrian-Ordovician sedimentary rocks of the Cookson Group is generally marked by the Sawyer Brook Fault, along which considerable transcurrent movement has occurred (Park et al. 2008).

Volcanic rocks become abundant up-section in the Oak Bay Formation and the contact with the overlying Waweig Formation, a sequence of moderately dipping, light pink, fossiliferous, fine-grained sandstone and siltstone interbedded with felsic and lesser mafic tuffs, is gradational (Fyffe et al. 1999). A felsic tuff in the Waweig Formation yielded an early Silurian (Llandoverian) $\mathrm{U}-\mathrm{Pb}$ zircon date of $438 \pm 4 \mathrm{Ma}$ (Miller and Fyffe 2002). The Letete Formation, a complexly deformed, steeply dipping sequence of felsic and mafic tuffs interbedded with dark grey shale, lies along the southern margin of the Mascarene backarc basin between the St. George and Wheaton Brook faults (Fig. 1). Felsic tuff from the Letete Formation yielded an early Silurian (Llandoverian) $\mathrm{U}-\mathrm{Pb}$ zircon date of $437 \pm 7 \mathrm{Ma}$ (Miller and Fyffe 2002). Mascarene strata to the east of the Saint George Batholith (Fig. 1) include mafic flows and tuffs of the Long 
Reach Formation and conformably overlying, fine-grained, feldspathic sandstone, siltstone, dacitic flows, and minor mafic tuffs of the Jones Creek Formation. Brachiopods indicate a late Llandoverian to early Wenlockian age for the Long Reach Formation (McCutcheon and Ruitenberg 1987), and associated dacitic volcanic rocks have yielded an early Silurian (early Wenlockian) U-Pb zircon date of $432 \pm 2 \mathrm{Ma}(\mathrm{N}$. Van Wagoner, written communication to M. McLeod, 2001). An equivalent sequence of volcanic rocks lying beneath the late Silurian Eastport Formation in adjacent Maine has suprasubduction-zone geochemical signatures (Llamas and Hepburn 2013).

The early Silurian volcanic sequences of the Oak Bay, Waweig, Long Reach, Jones Creek, and Letete formations, which are at least partially coeval with the volcanic arc rocks in the Kingston Group, are considered here to have been generated in a continental backarc basin in an extensional suprasubduction-zone environment (Fyffe et al. 1999; Barr et al. 2002; White et al. 2006; van Staal et al. 2009). Fossil and geochronological data are consistent with a period of uplift and erosion or non-deposition of Silurian strata in the Mascarene backarc basin in the mid- to Wenlockian. This hiatus, delineated radiometrically by the age of the youngest suprasubduction-zone related volcanism (432 $\pm 2 \mathrm{Ma})$ and oldest non-arc plutonism $(428 \pm 1 \mathrm{Ma})$ constrains the timing of the closure of the Acadian Seaway and collision of Avalonia with the Ganderian margin of composite Laurentia to the mid-Silurian.

The mid-Silurian hiatus in the Mascarene backarc basin was followed by deposition of the shallow-marine to subaerial succession correlated with the Eastport Formation in Maine (Fyffe et al. 1999). The Eastport Formation in New Brunswick, which occurs along the southern margin of the Saint George Batholith to the north of the St. George Fault (Fig. 1), comprises a gently southerly dipping succession of mafic and felsic flows and tuffs interbedded with peritidal to subaerial, red sandstone and siltstone. Felsic flows in the middle section of the Eastport Formation are enriched in $\mathrm{Zr}$ (Van Wagoner et al. 2002), suggesting that they may be the extrusive equivalents of the peralkaline Welsford, Jake Lee Mountain, and Parks Brook granites. The Eastport volcanic rocks have within-plate geochemical signatures and have been reported to have a late Ludlovian to early Pridolian age based on the poorly documented, preliminary $\mathrm{U}-\mathrm{Pb}$ zircon date of $423 \pm 1 \mathrm{Ma}$ (Van Wagoner et al. 2002). The location of the dated felsic flow is not known with certainty but it was likely collected about $1 \mathrm{~km}$ above the base of the Eastport Formation.

\section{LATE SILURIAN - EARLY DEVONIAN PLUTONISM}

The bulk composition, spatial distribution, and timing of emplacement of the various Silurian (late Wenlockian to Pridolian) to Early Devonian (Lochkovian to Emsian) plutonic rocks in southwestern New Brunswick are discussed below in relationship to the tectonomagmatic evolution of the Kingston arc-Mascarene backarc system (Kingston and Mascarene belts on Fig. 1). As emphasized by Hyndman et al. (2005), convective heat flow in backarc regions can continue for some tens of millions of years after subduction stops; these hot and weak former backarcs can then become the focus of high temperature metamorphism, ductile deformation, and plutonism. Based on previously published geochronological data, the composite Saint George Batholith was emplaced into the Mascarene backarc basin during three separate intervals (428 to $422 \mathrm{Ma}$; 403 to $390 \mathrm{Ma}$; and 367 to $366 \mathrm{Ma}$ ), covering a time span of approximately 60 million years (Bevier 1989, 1990; McLeod 1990; Whalen et al. 1996; Thorne et al. 2002, 2008; Davis et al. 2004; Barr et al. 2010). The new results reported above indicate magmatic activity also occurred in the backarc between 418 and $413 \mathrm{Ma}$ (Table 1) and indicate that the tectonomagmatic history of the Saint George Batholith was more protracted than previously envisioned. All these intrusive episodes took place after the eruption of suprasubduction - zone related volcanism in the Mascarene backarc basin had ceased at $432 \pm 2 \mathrm{Ma}$.

\section{Silurian (late Wenlockian to Pridolian) magmatism}

The Silurian (late Wenlockian to Pridolian) 'A-type' granite plutons that were emplaced along the southern margin of the Mascarene backarc basin (Welsford, Jake Lee Mountain, Parks Brook, Utopia granites, and felsic components of the Bocabec Gabbro) generally show little evidence of deformation compared to the minor intrusions described below along the northern margin of the basin. Emplacement of the southern Silurian plutons overlapped with the eruption of bimodal flows and tuffs of the Eastport Formation dated at $423 \pm 1 \mathrm{Ma}$ (Van Wagoner et al. 2002). The Welsford and Utopia granites have been previously dated by $\mathrm{U}-\mathrm{Pb}$ on zircon at $422 \pm 1$ and $428.3 \pm 1.0 \mathrm{Ma}$, respectively (Bevier 1990; Barr et al. 2010). The new results reported here include a $\mathrm{U}-\mathrm{Pb}$ date on monazite of $425.5 \pm$ 2.1 Ma for the less evolved phase of the Utopia Granite, U-Pb dates on zircon of $420.4 \pm 2.4$ and $420.0 \pm 3.5 \mathrm{Ma}$ for the more evolved phase of the Utopia Granite, and a U-Pb on zircon of $418.0 \pm 2.3 \mathrm{Ma}$ for the Jake Lee Mountain Granite, which straddles the Pridolian-Lochkovian boundary (Fig. 11; Table 1). The undated Parks Brook peralkaline granite must be older than $420 \mathrm{Ma}$ as it is veined by the Utopia Granite.

The elongated shapes of these high-level 'A-type' plutons suggest that their emplacement was at least partly controlled by high heat flow along pre-existing, extensional fault-structures in the basement rocks defining the 'active' southeastern boundary of the Mascarene backarc basin (Fig. 1). Only the Jake Lee Mountain pluton displays evidence of significant shearing, likely attributable to late-stage movement on the St. George Fault (Figs. 1 and 2). More significant fault displacement along the southern margin of the backarc basin appears to have been taken up largely 
within the highly strained strata of the Letete Formation, located farther to the south between the St. George and Wheaton Brook faults (Fyffe et al. 1999).

The peralkaline, amphibole-bearing Welsford and Jake Lee Mountain granites, and biotite-bearing, Utopia Granite are classified as 'A-type' granites (Whalen 1986; Whalen et al. 1987). The generation of the peralkaline plutons may have involved partial melting of subcontinental lithospheric mantle (Whalen et al. 2006), whereas the generation of the contemporaneous 'aluminous A-type' Utopia Granite likely involved partial melting of dehydrated, granulite-facies, lower continental crust (King et al. 1997). Underplating of the lithosphere with mantle-derived mafic magma is required to produce the high temperatures required to melt the relatively anhydrous protoliths of 'A-type' granites. Neodymium epsilon values $\left[\epsilon_{\mathrm{Nd}}(430 \mathrm{Ma})\right]$ of +2.7 for granite from the Bocabec Gabbro, + 2.3 from the Utopia biotite granite, and +3.4 from the Welsford peralkaline granite indicate some mixing of mantle-derived mafic magma with the partial melts (Whalen et al. 1994; Whalen et al. 2006).

The Sawyer Brook Fault acted as a brittle, normal fault along the northern margin of the Mascarene backarc basin during deposition of the early Silurian Oak Bay conglomerate (Stringer and Burke 1985; Fyffe et al. 1999). Subsequently, a series of mafic dykes were emplaced into this margin of the backarc basin, along a probable splay off the Sawyer Brook Fault. The dykes, each about $30 \mathrm{~m}$ in width, occupy a $300 \mathrm{~m}$-wide, northeast-trending dextral shear zone along the northwestern margin of the Magaguadavic pluton. As seen in gold exploration trenches in the Clarence Stream area (CS on Fig. 1), the dykes contain penetrative schistosity of aligned biotite and actinolite that is parallel to the trend of the dykes and cross-cuts an earlier phyllitic cleavage in the Silurian volcanic and sedimentary host rocks of the Waweig Formation; locally the dykes are highly boudinaged. The late schistosity in the sedimentary rocks, defined by muscovite and biotite, wraps around cordierite porphyroblasts, which contain relicts of the earlier phyllitic cleavage (Thorne and Lentz 2001; Park et al. 2008; Thorne et al. 2008). The mafic dykes in the Clarence Stream shear zone are petrochemically similar to, and may represent offshoots from, the Bocabec Gabbro. If this correlation is correct, the dykes were emplaced in the later part of the Silurian (Ludlovian to Pridolian) at about $422.1 \pm 1.3 \mathrm{Ma}$ (Clarke et al. 2017).

High-strain shear zones have also been mapped in the St. Croix and Fredericton belts to the northwest of the Sawyer Brook Fault. The Mohannes Granite, located about $10 \mathrm{~km}$ to the west of the area shown in Fig. 1, is light grey, granodiorite to monzogranite that was emplaced into Cambrian-Ordovician sedimentary rocks along the northern margin of the St. Croix belt (Fyffe et al. 1991). This oblong, relatively small, 'I-type' pluton, which yielded a preliminary $\mathrm{U}-\mathrm{Pb}$ emplacement age on zircon of 420 $\pm 5 \mathrm{Ma}$ (Fyffe and Bevier 1992), contains a penetrative, northeast-trending, cataclastic fabric defined by aligned augen of plagioclase and potassium feldspar set in a granulated quartz matrix. Like in the contact aureole of the mafic dykes in the Clarence Stream area, cordierite porphyroblasts in the host rocks of the Mohannes Granite show evidence of growth during deformation.

\section{Early Devonian (Lochkovian to Emsian) magmatism}

The John Lee Brook, Jimmy Hill, and Magaguadavic granites, which form the northwestern part of the Saint George Batholith (Fig. 1), are all Early Devonian in age. Both the John Lee Brook and Jimmy Hill plutons appear to be entirely confined to the St. Croix and Fredericton belts on the north side of the Sawyer Brook Fault. The new LA ICP-MS in situ U-Pb age of $413.3 \pm 2.1 \mathrm{Ma}$ indicates that the John Lee Brook Granite was emplaced during the Lochkovian stage (Ogg et al. 2016). Also, the U-Pb zircon crystallization ages of $415.5 \pm 2.1 \mathrm{Ma}$ obtained from the newly recognized Wellington Lake Granite indicates that some high-field-strength-element-enriched magmatic activity was taking place within the Mascarene backarc basin along the southern margin of the Saint George Batholith in early Lochkovian time.

The John Lee Brook pluton has an elongated shape but does not display a fabric, suggesting that its emplacement took place during the waning stages of transpressional tectonic activity. In marked contrast, the Magaguadavic pluton is roughly circular in outline indicating that its emplacement post-dated major fault movement. Like the Tower Hill Granite, which lies entirely in the St. Croix belt, the two-mica John Lee Brook Granite is peraluminous with a high Aluminum Saturation Index (ave. ASI of $1.08)$ and low $\epsilon_{\mathrm{Nd}}(400 \mathrm{Ma})$ value of +0.3 compared to the other plutons comprising the Saint George Batholith (Whalen et al. 1996). It thus has properties transitional to 'S-type' granites and was likely derived in part by melting or assimilation of supracrustal metasedimentary rocks (Chappell and White 1974). In contrast, the metaluminous megacrystic Magaguadavic Granite, with an ASI of 0.9 and $\epsilon_{\mathrm{Nd}}(400 \mathrm{Ma})$ of +2.0 , has 'I-type' characteristics and its generation can be attributed to partial melting of metaigneous rocks in the lower crust (Chappell and White 1974; Whalen et al. 1994, 1996; Yang et al. 2008); the presence of large potassium feldspar phenocrysts indicates that the magma may have been sequestered in the deep crust for some time before rising and solidifying nearer to the surface (McLeod 1990).

The Magaguadavic Granite was emplaced during the Emsian Stage of the Early Devonian as indicated by previously published $\mathrm{U}-\mathrm{Pb}$ dates on zircon of $396 \pm 1$ Ma (Bevier 1989; Davis et al. 2004). The John Lee Brook and Magaguadavic granites differ markedly in texture, mineralogy, and chemistry, as well as in age. The John Lee Brook Granite generally contains biotite, muscovite, and garnet; and is high in silica (ave. $\mathrm{SiO}_{2}=74.0 \%$ ). The 
Magaguadavic Granite contains megacrysts of potassium feldspar, and biotite and hornblende, and is low in silica (ave. $\mathrm{SiO}_{2}=68.5$ wt.\%).

A m-wide granitic dyke in the Clarence Stream shear zone (CS on Fig. 1) has yielded a U-Pb (monazite age) of $395.5 \pm 0.5 \mathrm{Ma}$ (Davis et al. 2004). Its age and the presence of potassium-feldspar phenocrysts (1 to $2 \mathrm{~cm}$ in length) suggest that the granitic dyke is an offshoot of the nearby Magaguadavic pluton. However, unlike the main pluton, the dyke exhibits a weak tectonic fabric. It could be concluded from this that dextral shearing associated with the Sawyer Brook Fault may have taken place episodically over a period of at least 25 million years, i.e., between 421 $\mathrm{Ma}$, the presumed age of intrusion of the sheared mafic dykes in the Clarence stream area, and $396 \mathrm{Ma}$, the age of the associated foliated granitic dyke (Thorne and Lentz 2001; Park et al. 2008; Thorne et al. 2008). Alternatively, the shearing in the granitic dyke may reflect local re-activation of the Sawyer Brook splay within the contact aureole of the Magaguadavic Granite.

The Tower Hill Granite, which transects the core of a late antiform in the St. Croix belt (Fig. 1), is undeformed, except where it is intersected by the northwest-trending Oak Bay Fault (Fyffe et al. 1991, 1999; Castonguay et al. 2003). It contains both biotite and muscovite, is highly peraluminous (ASI of 1.14), and has a negative $\epsilon_{\mathrm{Nd}}(400 \mathrm{Ma})$ value of - 0.4 (Whalen et al. 1996). A high temperature-low pressure metamorphic assemblage of biotite, andalusite, staurolite, garnet, muscovite, and quartz is developed in the sedimentary rocks up to $500 \mathrm{~m}$ from the granite (Ruitenberg 1967; Fyffe et al. 1991). A minimum age of emplacement for the Tower Hill Granite is given by an Rb-Sr muscovite isochron date of $401 \pm 4 \mathrm{Ma}$ (Whalen et al. 1996). An undeformed microgranite dyke, located approximately 2 $\mathrm{km}$ east of Tower Hill, yielded a U-Pb zircon age of $409 \pm 2$ Ma (Davis et al. 2004).

\section{DISCUSSION AND CONCLUSIONS}

Average bulk chemical compositions of plutons comprising the Saint George Batholith and satellite Tower Hill pluton have been calculated using published analyses from McLeod (1990) and Whalen (1993) to supplement the data reported herein for the newly dated samples. These averaged values confirm that the spatial and temporal variations observed from southeast to northwest across the batholith are reflected systematically in the trace-element, $\mathrm{REE}$, and isotopic Nd geochemistry of the clustered plutons (Figs. 23 and 24). On the Pearce et al. (1984) discrimination diagrams, granitic samples from the Bocabec, Utopia, Welsford, Jake Lee Mountain, and Wellington Lake plutons all fall in the 'within -plate' 'field whereas the John Lee Brook, Jimmy Hill, Magaguadavic, and Tower Hill plutons fall mainly on the boundary between the' syn-collisional' and 'volcanic-arc' fields (Fig. 24).

The geochemical variation across the Saint George
Batholith can be explained in terms of the transition of the Kinston arc-Mascarene backarc system from an extensional arc to transpressional tectonic environment during the Acadian orogeny, which was caused by closure of the Acadian Seaway and collision of the Avalonian microcontinent with the composite Laurentian margin (van Staal et al. 2009). The initial extensional nature of the Kingston arc is indicated by the early Silurian emplacement of a high-level bimodal intrusive complex into the host volcanic-arc rocks of the Kingston Group. Mafic and granitic dykes in this complex have active-continentalmargin and within-plate signatures, respectively (Eby and Currie 1993). A subsequent change to a compressive environment is indicated by the presence of a zone of low temperature-high pressure metamorphism along the southeastern margin of the Kingston arc, which occurred after emplacement the late Llandoverian intrusive complex at $436 \pm 2 \mathrm{Ma}$ (Doig et al. 1990) and prior to $420 \pm 2 \mathrm{Ma}$, the oldest ${ }^{40} \mathrm{Ar} /{ }^{39} \mathrm{Ar}$ cooling age of metamorphic amphibole defining the foliation in the mafic dykes (Nance and Dallmeyer 1993; Barr et al. 2002; White et al. 2006).

A much later, high temperature-intermediate pressure 'regional contact' metamorphic event associated with emplacement of the Tower Hill Granite at about $401 \mathrm{Ma}$ is evident in the St. Croix belt to the northwest of the Mascarene backarc basin (Fyffe et al. 1991; Whalen et al. 1996). Staurolite and garnet are present in pelitic rocks of both the low-pressure metamorphic assemblage in the St. Croix belt and high-pressure assemblage in the Kingston belt but the garnets in the St. Croix assemblage are significantly lower in magnesium and higher in manganese content (Fyffe et al. 1991; White et al. 2006). The contrast between the penetrative deformation apparent in the Pridolian Mohannes Granite in the St. Croix belt, and the relatively undeformed nature of the late Wenlockian to Pridolian plutons of the Saint George Batholith on opposite sides of the Sawyer Brook Fault (Fig. 1), is likely a reflection of the depth of emplacement and subsequent uplift of the hotter, deeply buried, complexly deformed, CambrianOrdovician sedimentary sequence in the northwest, compared to the cooler, near-surface, gently dipping volcanic sequence (Eastport Formation) exposed along the southeastern margin of the Mascarene backarc basin. This strain gradient is evident from the strong ductile fabrics present in the more deeply buried, lower part of the Silurian volcanic sequence (Waweig Formation) and contained mafic dykes now exposed along the northwestern margin of the Mascarene backarc basin in Clarence Stream area (CS on Fig. 1).

Emplacement of late Wenlockian to Pridolian Bocabec, Utopia, Jake Lee Mountain, Parks Brook, and Welsford plutons into the host volcanic rocks of the Mascarene backarc basin coincided with the change from early Silurian suprasubduction-zone influenced volcanism to late Silurian bimodal volcanism in the backarc area. This change in tectonomagmatic environment is attributed to 
the arrival of the leading edge of Avalonia at the trailing edge of Ganderia of composite Laurentia. The attempted subduction of the buoyant Avalonia microcontinent plate caused a decrease in the angle of subducting slab beneath the Kingston arc leading to increased coupling between the upper Ganderian and lower Avalonian plates, resulting in the cessation of arc-related volcanic activity. Further plate convergence led to partitioning of strain into orthogonal shortening and margin-parallel, strike-slip components focused in the thin, hot and weakened backarc lithosphere (e.g., Hyndman et al. 2005). As the downgoing Avalonian plate reached higher temperatures at greater depths, the dense, dehydrated, subducting oceanic slab ruptured and broke away from the more buoyant continental part of the lower plate, and compressive forces between the Ganderian and Avalonian plates diminished due to the loss of slab pull (Davies and von Blanckenburg. 1995; Ellis et al. 1998; Barnes et al. 1998). Thermomechanical modelling by Gerya et al. (2004) indicates that slab break-off occurs from 5 to 30 million years after collision and that ensuing magmatism can last between 10 to 20 million years. In the Kingston arc-backarc system, slab break-off and the termination of continental subduction is interpreted to have occurred in the mid-Silurian between $432 \pm 2 \mathrm{Ma}$, the youngest age of arc volcanism, and $428 \pm 1 \mathrm{Ma}$, the oldest age of postcollision plutonism in the Saint George Batholith. Partial melting of the thin, hot lithosphere inherited from the opening of the Mascarene backarc basin would have been promoted by upwelling and decompressional melting of the asthenospheric mantle following slab-break-off. Such a mechanism accounts for the generation of voluminous bimodal (gabbroic and granitic) magmatism represented by the Bocabec, Utopia, Welsford, Jake Lee Mountain, Parks Brook, and Wellington Lake plutons lasting over a period of about 13 million years (Fig. 11; Tables 1 and 3).

Table 3. $\mathrm{La} / \mathrm{Yb}$ and epsilon $\mathrm{Nd}(\mathrm{T})$ values for the Saint George Batholith and Tower Hill Pluton.

\begin{tabular}{lccc}
\hline Granitic Pluton & $\mathbf{L a} / \mathbf{Y b}$ & $\mathbf{\epsilon}_{\mathbf{N d}}(\mathbf{T})$ & Age $(\mathbf{M a})$ \\
\hline Bocabec & $5.8-10.3$ & 2.7 & $422.1 \pm 1.3^{*}$ \\
Utopia & $3.2-10.2$ & 2.2 & $428.3 \pm 1.0$ to $420.4 \pm 2.4$ \\
Welsford & $7.0-10.0$ & 3.3 & $422 \pm 1$ \\
Jake Lee Mountain & $6.3-7.3$ & - & $418.0 \pm 2.3$ \\
Wellington Lake & 10.7 & - & $415.5 \pm 2.1$ \\
John Lee Brook & $5.5-18.0$ & 0.2 & $413.3 \pm 2.1$ \\
Jimmy Hill & $20.8-25.3$ & - & $403 \pm 2$ \\
Magaguadavic & $24.3-29.3$ & 1.5 & $396 \pm 1$ \\
Tower Hill & $37.8-40.5$ & -0.4 & $401 \pm 4$ \\
\hline
\end{tabular}

* The granite is assumed to be coeval with the U-Pb dated Bocabec Gabbro (Clarke et al . 2017).
Systematic variation in $\mathrm{La} / \mathrm{Yb}$ values is evident across the Saint George Batholith: the more southerly group of plutons (Bocabec, Utopia, Welsford, Jake Lee Mountain, and Wellington Lake) typically have (a) a range of La/ $\mathrm{Yb}$ values of less than 11, (b) a relatively high isotopically positive epsilon $\mathrm{Nd}$ values, and (c) ages ranging from late Wenlockian to early Lochkovian; those to the north (John Lee Brook; Jimmy Hill, Magaguadavic, and satellite Tower Hill pluton) have (a) considerably higher $\mathrm{La} / \mathrm{Yb}$ values; (b) low positive to slightly negative epsilon Nd values; and (c) ages ranging from late Lochkovian to Emsian (Table 3). Whalen et al. (2006) documented a similar increase in $\mathrm{La} / \mathrm{Yb}$ and decrease in epsilon $\mathrm{Nd}$ in Silurian plutons at increasing distances to west of the Dog Bay Line in central Newfoundland. They interpreted the Dog Bay Line to represent the suture zone between Laurentia and Ganderia that resulted from closure of the intervening Exploits basin by west-directed subduction of backarc oceanic crust. The variation $\mathrm{La} / \mathrm{Yb}$ and epsilon $\mathrm{Nd}$ in these plutons was attributed to slab break-off resulting in a change from shallow-level, garnet-absent melting of juvenile crust proximal to the suture zone and deeper level melting of old granitic basement in the garnet stability field farther to the west.

Hildebrand and Whalen (2014) defined separate 'arc' and 'slab failure' plutonic fields on $\mathrm{Nb} / \mathrm{Y}$ versus $\mathrm{Sr} / \mathrm{Y}$, and $\mathrm{La} / \mathrm{Yb}$ versus $\mathrm{Sr} / \mathrm{Y}$ diagrams based the trace-element geochemistry of plutons in the Cretaceous Peninsula Ranges Batholith in coastal California and Mexico. However, they noted that their proposed discrimination fields should not be considered universally applicable because of the inherent tectonic complexities involved in the evolution of orogenic belts; instead the division of the Cretaceous plutons into 'arc' (low La/Yb) and 'slab failure' (high $\mathrm{La} / \mathrm{Yb}$ ) types was determined primarily by the timing of their emplacement with respect to collision and uplift rather than by geochemistry alone. With this in mind, the two fields on Hildebrand and Whalen's discrimination diagrams are used herein to empirically determine which plutons in the Saint George Batholith were likely to have had residual garnet present in their source regions.

The plutons of the Saint George Batholith and satellite Tower Hill pluton fall into the same two groupings on the Hildebrand and Whalen (2014) diagram (Fig. 26) that they do on the Pearce et al. (1984) discrimination diagram (Fig. 24). The Magaguadavic, Jimmy Hill, John Lee Brook, and Tower Hill granites plot in or near the boundary of the 'garnet present' field. The four samples from the John Lee Brook Granite from McLeod (1990), which show wide variation in element ratios (Table 3), have been plotted as individual points rather than as an average; the two samples from the southeastern part of the pluton (ave. La/ $\mathrm{Yb}$ of 7.4) appear to be more evolved with higher silica and $\mathrm{Rb} / \mathrm{Sr}$ values compared to the two samples from the northeast (ave. $\mathrm{La} / \mathrm{Yb}$ of 14.4). Samples from the younger Jimmy Hill and Magaguadavic plutons (Table 3) plot well 

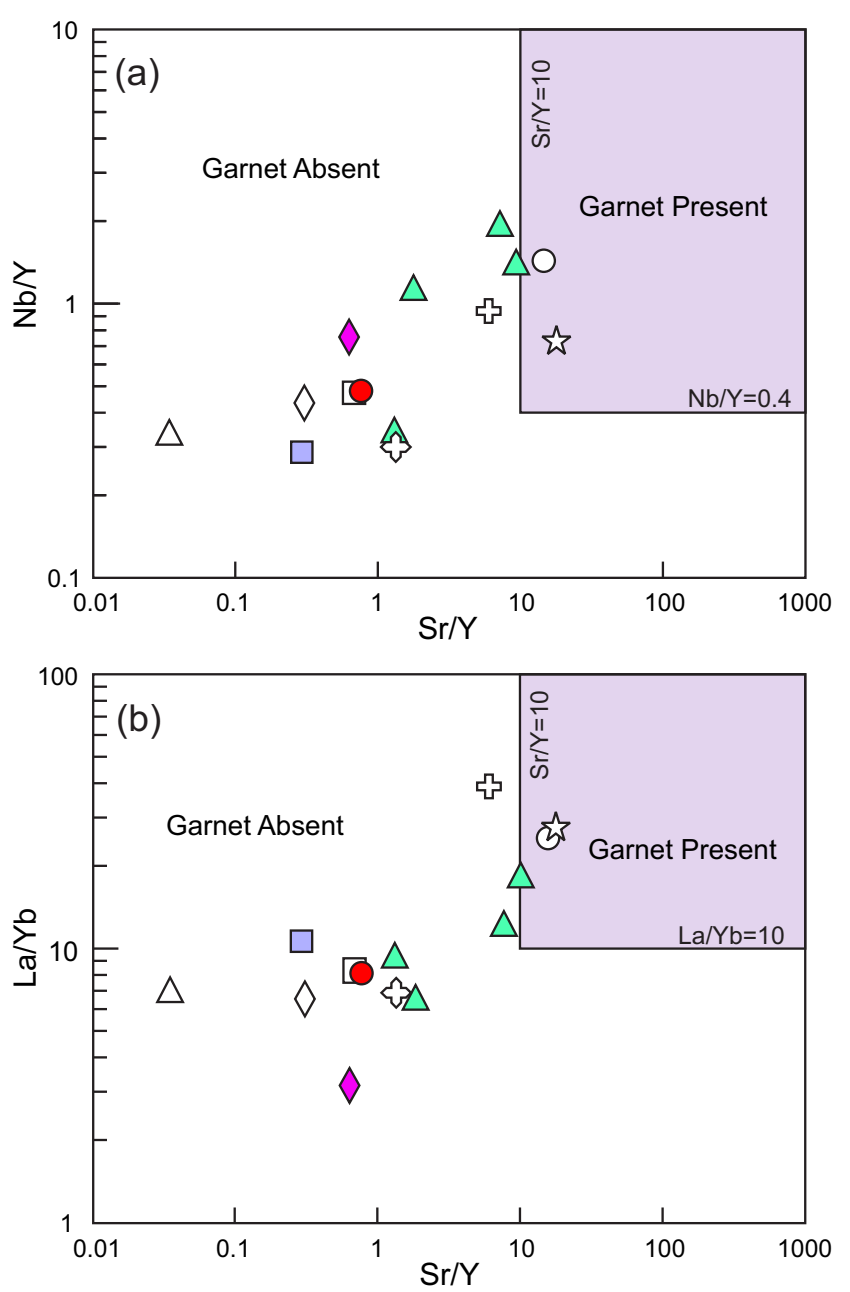

Figure 26. Tectonomagmatic discrimination diagrams from Hildebrand and Whalen (2014) for plutons of the Saint George Batholith and satellite Tower Hill pluton. (a) $\mathrm{Nb} / \mathrm{Y}$ vs. Sr/Y; (b) La/Yb vs. Sr/Y. See Figure 22 for symbols.

into the 'garnet present field (Fig. 26). The transition to deeper level partial melting apparently occurred during the Lochkovian Stage of the Early Devonian based on the emplacement age of $415.5 \pm 2.1 \mathrm{Ma}$ for the Wellington Lake Granite, the youngest 'A-type' pluton, and the emplacement age of $413.3 \pm 2.1 \mathrm{Ma}$, for the John Lee Brook Granite, the oldest 'S-type' pluton in the backarc region; the former was likely generated at least in part by partial melting of Neoproterozoic volcanic and plutonic rocks underlying the Mascarene belt, and the latter at least in part by granulite-facies dehydration melting of pelitic rocks of the St. Croix belt.

Convective heating and partial melting of the adjacent, thick crust of the St. Criox belt, which marks the northwestern 'passive' boundary of the Mascarene backarc basin, may be responsible for the generation of Early Devonian magmatism at greater depths compared to the Silurian magmatic activity to the southeast. Prograde metamorphism of the bounding thick crust may have led to formation of a dense, eclogitic lower crustal root that had detached from the more buoyant overlying granulitic crust and sank, together with its attached underlying lithospheric mantle, into the convecting asthenosphere of the backarc region (see Krystopowicz and Currie 2013). Subsequent upwelling of the asthenospheric mantle then induced widespread partial melting of the lower crust under 'garnetpresent' conditions to generate the 'I-type' Jimmy Hill, Magaguadavic, and 'S-type' Tower Hill plutons (Fig. 24). These plutons then rose to higher levels in the crust, where they solidified during the Emsian between $403 \pm 2$ and 396 $\pm 1 \mathrm{Ma}$ (Table 3). Isostatic rebound within the St. Croix belt is marked by the domal area of high temperaturelow pressure contact metamorphic zone surrounding the Tower Hill pluton. Deformation of pegmatitic and aplitic dykes and associated auriferous quartz veins located along the northwestern margin of the undeformed, circular, Magaguadavic Granite is focused along reactivated shear fault splays of the Sawyer Brook Fault (Thorne et al. 2008).

The eastern part of the Saint George Batholith was formed 30 million years later with the emplacement of the $600 \mathrm{~km}^{2}$, tin-enriched, post-orogenic, Late Devonian Mount Douglas Granite (Fig. 1). The recent mapping and geochronology has shown that the Mount Douglas and other plutons of Silurian to Late Devonian age that comprise the Saint George Batholith actually occur as a cluster of individual intrusions separated by screens of sedimentary and volcanic country rocks, rather than as the continuous mass of amalgamated plutons depicted on earlier maps.

\section{ACKNOWLEDGEMENTS}

The authors would like to thank Malcolm McLeod, Adrian Park, and Dave Stevens for their helpful advice. Dr. Douglas Hall (UNB Microscopy and Microanalyses Facility) is thanked for help with the SEM-BSE imaging. We thank Brandon Boucher for help with the laser ablation ICP-MS data. Serge Allard provide ARCGIS base maps and Terry Leonard drafted the geology maps. Joe Whalen and Jim Mortensen provided insightful suggestions that helped to improve the petrogenetic interpretations presented in the paper. Project funding was provided by New Brunswick Energy and Resource Development, UNB President's Doctoral scholarship (University of New Brunswick), and the New Brunswick Innovation Foundation. Chris McFarlane and David Lentz hold NSERC Discovery grants. 


\section{REFERENCES}

Aleinikoff, J.N., Schenck, W.S., Plank, M.O., Srogi, L., Fanning, C.M., Kamo, S.L., and Bobyshell, H. 2006. Deciphering igneous and metamorphic events in highgrade rocks of the Wilmington Complex, Delaware: Morphology, cathodoluminescence and backscattered electron zoning, and SHRIMP U-Pb geochronology of zircon and monazite. Geological Society of America Bulletin, 118, pp. 39-64. https://doi.org/10.1130/ B25659.1

Anderson, T. 2002.Correction of common lead in $\mathrm{U}-\mathrm{Pb}$ analyses that do not report ${ }^{204} \mathrm{~Pb}$. Chemical Geology, 192, pp. 59-79. https://doi.org/10.1016/S00092541(02)00195-X

Azadbakht, Z., McFarlane, C.R.M., and Lentz, D.R. 2016. Precise $\mathrm{U}-\mathrm{Pb}$ ages for the cogenetic alkaline Mount LaTour and peraluminous Mount Elizabeth granites of the South Nepisiguit River Plutonic Suite, northern New Brunswick, Canada. Atlantic Geology, 52, pp. 189-210. https://doi.org/10.4138/atlgeol.2016.009

Barnes, P.M., Mercier de Lépinay, B., Collot, J-Y, Delteil, J., and Audru, J.-C. 1998. Strain partitioning in the transition area between oblique subduction and continental collision, Hikurangi margin, New Zealand. Tectonics, 17, pp. 534-557. https://doi. org/10.1029/98TC00974

Barr, S.M., White, C.E., and Miller, B.V. 2002. The Kingston terrane, southern New Brunswick, Canada. Evidence for an Early Silurian volcanic arc. Geological Society of America, Bulletin 114, pp. 964-982. https://doi. org/10.1130/0016-7606(2002)114<0964:TKTSNB >2.0 .CO;2

Barr, S.M., Mortensen, J.K., and Bevier, M.L. 2010. A precise age for the Utopia Granite, southwestern New Brunswick, Canada. Atlantic Geology, 46, pp. 36-42. https://doi.org/10.4138/atlgeol.2010.004

Bevier, M.L. 1989. U-Pb geochronologic studies of igneous rocks in New Brunswick. In Project Résumés for 1988, Thirteenth Annual Review of Activities. Edited by S.A. Abbott. New Brunswick Department of Natural Resources and Energy, Minerals and Energy Division, Information Circular 88-2, pp. 134-140.

Bevier, M.L. 1990. Preliminary U-Pb geochronologic results for igneous and metamorphic rocks, New Brunswick. In Project Summaries for 1989, Fourteenth Annual Review of Activities. Edited by S.A. Abbott. New Brunswick Department of Natural Resources and Energy, Minerals and Energy Division, Information Circular 89-2 (Second Edition), pp. 208-212

Castonguay, S. Watters, S., and Ravenelle, J.F. 2003. Preliminary report on the structural geology of the Clarence Stream-Moores Mills area, southwestern New Brunswick: implications for gold exploration. Geological Survey of Canada, Current Research 2003D2, $10 \mathrm{p}$.
Chappell, B.W. and White, A.J.R. 1974. Two contrasting granite types. Pacific Geology, 8, pp. 173-174.

Cherry, M.E. and Trembath, L.T. 1978. Structural state and composition of alkali feldspar in granites of the St. George pluton, south-western New Brunswick. Mineralogical Magazine, 42, p. 391-399. https://doi. org/10.1180/minmag.1978.042.323.11

Christiansen, E.H. and Keith, J.D. 1996. Trace-element systematics in silicic magmas: a metallogenic perspective. In Trace Element Geochemistry of Volcanic Rocks: Applications for Massive Sulfide Exploration. Edited by D.A. Wyman. Geological Association of Canada, Short Course Notes 12, pp. 115-151.

Churchill-Dickson, L. 2004. A Late Silurian (Pridolian) age for the Eastport Formation, Maine: a review of the fossil, stratigraphic, and radiometric-age data. Atlantic Geology, 40, pp. 189-195. https://doi.org/10.4138/1038

Clarke, D.B., McFarlane, C.R.M., Hamilton, D., and Stevens, D. 2017. Forensic igneous petrology: locating the source quarry for the "black granite" Titanic headstones in Halifax, Nova Scotia, Canada. Atlantic Geology, 53, pp. 87-114. https://doi.org/10.3749/canmin.1600037

Currie, K.L. 1988. The western end of the Avalon Zone in southern New Brunswick. Maritime Sediments and Atlantic Geology, 24, pp. 339-352. https://doi. org/10.4138/1661

Davies, J.H. and von Blanckenburg, F. 1995. Slab breakoff: a model of lithospheric detachment and its test in the magmatism and deformation of collisional orogens. Earth Planetary Science Letters, 129, pp. 85-102. https://doi.org/10.1016/0012-821X(94)00237-S

Davis, W., Chi, G., Castonguay, S., and McLeod, M.J. 2004. Temporal relationships between plutonism, metamorphism, and gold mineralization in southwestern New Brunswick: U-Pb and ${ }^{40} \mathrm{Ar} /{ }^{39} \mathrm{Ar}$ geochronological constraints. Geological Survey of Canada, Current Research 2004-F2, 20 p. https://doi. org/10.4095/215841

Doig, R., Nance, R.D., Murphy, J.B., and Casseday, R.P. 1990. Evidence for Silurian sinistral accretion of Avalon terrane in Canada. Geological Society of London Journal, 147, pp. 927-930. https://doi.org/10.1144/ gsjgs. 147.6.0927

Eby, G.N. 1992. Chemical subdivision of the A-type granitoids: petrogenetic and tectonic implications. Geology,20,pp.640-644.https://doi.org/10.1130/00917613(1992)020<0641:CSOTAT>2.3.CO;2

Eby, G.N. and Currie, K.L. 1993. Petrology and geochemistry of the Kingston complex-a bimodal sheeted dyke suite in southern New Brunswick. Atlantic Geology, 29, pp. 121-135. https://doi.org/10.4138/1995

Ellis, S., Beaumont, C., Jamieson, R.A., and Quinlin, G. 1998. Continental collision including a weak zone; the vice model and its application to the Newfoundland Appalachians. Canadian Journal of Earth Sciences, 35, pp. 1323-1346. https://doi.org/10.1139/e97-100 
Fyffe, L.R. 1971. Petrogenesis of the adamellite-diorite transition, southwestern New Brunswick. Unpublished M.Sc. thesis, University of New Brunswick, Fredericton, New Brunswick, 130 p.

Fyffe, L.R. 1998. Bedrock geology of the Jake Lee Mountain area (NTS 21 G/2g), Charlotte County, New Brunswick. New Brunswick Department of Natural Resources and Energy, Map Plate 98-25, scale 1: 20000.

Fyffe, L.R., and Bevier, M.L. 1992. A U-Pb date on the Mohannes pluton of southwestern New Brunswick. Atlantic Geoscience Society Abstract. Atlantic Geology, 28, p.198.

Fyffe, L.R. and Riva, J. 1990. Revised stratigraphy of the Cookson Group of southwestern New Brunswick and adjacent Maine. Atlantic Geology, 26, 3, pp. 271-275. https://doi.org/10.4138/1709

Fyffe, L.R. and Riva, J.F.V. 2001. Regional significance of graptolites from the Digdeguash formation of southwestern New Brunswick. In Current Research 2000. Edited by B.M.W. Carroll. New Brunswick Department of Natural Resources and Energy, Minerals and Energy Division, Mineral Resource Report 2001-4, pp. 47-54.

Fyffe, L.R., McLeod, M.J., and Ruitenberg, A.A. 1991. A geotraverse across the St. Croix-Avalon terrane boundary, southern New Brunswick. In Geology of the Coastal Lithotectonic Block and Neighboring Terranes, Eastern Maine and Southern New Brunswick. Edited by A. Ludman. New England Intercollegiate Geological Conference, $83^{\text {rd }}$ Annual Meeting, Princeton, Maine, Field Guide, Trip A-2, p. 13-54.

Fyffe, L.R., Pickerill, R.K., and Stringer, P. 1999. Stratigraphy, sedimentology and structure of the Oak Bay and Waweig formations, Mascarene Basin: implications for the paleotectonic evolution of southwestern New Brunswick. Atlantic Geology, 35, pp. 59-84. https:// doi.org/10.4138/2024

Fyffe, L.R., Johnson, S.C., and van Staal, C.R. 2011. A review of Proterozoic to Early Paleozoic lithotectonic terranes in the northeastern Appalachian orogen of New Brunswick, Canada, and their tectonic evolution during Penobscot, Taconic, Salinic, and Acadian orogensis. Atlantic Geology, 47, pp. 211-248. https://doi.org/10.4138/atlgeol.2011.010

Gerya, T.V., Yuen, D.A., and Maresch, W.V. 2004. Thermomechanical modelling of slab detachment. Earth and Planetary Science Letters, 226, pp. 101-116. https://doi.org/10.1016/j.epsl.2004.07.022

Hibbard, J.P., van Staal, C.R., Rankin, D.W., and Williams, H. 2006. Lithotectonic map of the Appalachian Orogen (North), Canada-United States of America; Geological Survey of Canada, Map 02042A, scale 1:1 500000.

Hildebrand, R.S. and Whalen, J.B. 2014. Arc and slabfailure magmatism in Cordilleran batholiths II - The Cretaceous Peninsular Ranges batholith of Southern and Baja California: Paul Hoffman Volume, Geoscience Canada, 41, pp. 399-458. https://doi.org/10.12789/ geocanj.2014.41.059
Hyndman, R.D., Currie, C.A., and Mazzotti, S.P. 2005. Subductionzonebackarcs, mobilebelts, andorgenicheat. GSA Today, 15, pp. 4-10. https://doi.org/10.1130/10525173(2005)015<4:SZBMBA >2.0.CO;2

Johnson, S.C. and McLeod, M.J. 1996. The New River Belt: A unique segment along the western margin of the Avalon composite terrane, southern New Brunswick, Geological Society of America, Special Paper 304, pp. 149-164. https://doi.org/10.1130/0-8137-2304-3.149

King, M.S. and Barr, S.M. 2004.Magnetic and gravity models across terrane boundaries in southern New Brunswick, Canada. Canadian Journal of Earth Sciences, 41, pp. 1027-1047. https://doi.org/10.1139/e04-046

King, P.L., White, A.J. R., Chappell, B.W, and Allen, C.M. 1997. Characterization and origin of aluminous A-type granites from the Lachan Fold Belt, southwestern Australia. Journal of Petrology, 38, pp. 371-391. https:// doi.org/10.1093/petroj/38.3.371

Krystopowicz, N.J. and Currie, C.A. 2013. Crustal eclogitization and lithosphere delamination in orogens. Earth and Planetary Science Letters, 361, pp. 195-207. https://doi.org/10.1016/j.epsl.2012.09.056

Le Maitre, R.W. 1989. A Classification of Igneous Rocks and Glossary of Terms. Recommendations of the IUGS Commission on the Systematics of Igneous Rocks. Oxford: Blackwell.

Llamas, A.P. and Hepburn, J.C. 2013. Geochemistry of Siluian-Devonian volcanic rocks in the Coastal Volcanic belt, Machias - Eastport, Maine: Evidence for a pre-Acadian arc. Geological Society of America, Bulletin, 125, pp. 1930-1942. https://doi.org/10.1130/ B30776.1

Ludwig, K. 2009. SQUID 2: A User's Manual. Berkeley Geochronology Center Special Publication 5, 110 p. URL <http://www.bgc.org/isoplot_etc/squid/ SQUID2_5Manual.pdf> January, 2016.

Martin, G. 2013. The granite industry of southwestern New Brunswick: a historical perspective. New Brunswick Department of Energy and Mines, Popular Geology Paper, 2013-1, $104 \mathrm{p}$.

McCutcheon, S.R. and Ruitenberg, A.A. 1987. Geology and mineral deposits, Annidale-Nerepis area, New Brunswick. New Brunswick Department of Natural Resources and Energy, Mineral Resources Division, Memoir 2, 141 p.

McFarlane, C.R.M. 2015. A geochronological framework for sedimentation and Mesoproterozoic tectonomagmatic activity in lower Belt-Purcell rocks exposed west of Kimberley, BC. Canadian Journal of Earth Sciences, 52, pp. 444-465. https://doi.org/10.1139/cjes-2014-0215

McLaughlin, K.J., Barr, S.M., Hill, M.D., Thompson, M.D., Ramezani, J., and Reynolds, P.H. 2003. The Moosehorn Plutonic, southeastern Maine and southwestern New Brunswick: age, petrochemistry and tectonic setting. Atlantic Geology, 39, pp. 123-146. https://doi.org/ $10.4138 / 1176$ 
McLeod, M.J. 1990. Geology, geochemistry and related mineral deposits of the Saint George Batholith; Charlotte, Queens and Kings counties, New Brunswick. New Brunswick Department of Natural Resources and Energy, Mineral Resources, Mineral Resource Report $5,169 \mathrm{p}$.

McLeod, M.J., Johnson, S.C., and Fyffe, L.R. 1998. Bedrock geology of the McDougall Lake area (NTS 21 G/7), Charlotte County, New Brunswick. New Brunswick Department of Natural Resources and Energy, Map Plate 98-25,scale 1: 20000.

McLeod, M.J., Johnson, S.C., and Krogh, T.E. 2003. Archived U-Pb (zircon) dates from southern New Brunswick. Atlantic Geology, 39, pp. 209-225. https:// doi.org/10.4138/1182

Miller, B.V. and Fyffe, L.R. 2002. Geochronology of the Letete and Waweig formations, Mascarene Group, southwestern New Brunswick. Atlantic Geology, 38, pp. 29-36.

Nance, R.D. and Dallmeyer, R.D. $1993 .{ }^{40} \mathrm{Ar} /{ }^{39} \mathrm{Ar}$ ages from the Kingston Complex, New Brunswick: evidence for Silurian-Devonian tectonothermal activity and implications for the accretion of the Avalon composite terrane. Journal of Geology, 101, pp. 375-388. https:// doi.org/10.1086/648230

Ogg, J.G., Ogg, G.M., and Gradstein, F.M. 2016. A concise geological time scale. Elsevier B.V. pp. 1-7.

Paces, J.B. and Miller, J.D., 1993. Precise U-Pb Ages of Duluth Complex and Related Mafic Intrusions, Northeastern Minnesota - Geochronological Insights to Physical, Petrogenetic, Paleomagnetic, and Tectonomagmatic Processes Associated with the 1.1 Ga Midcontinent Rift System. Journal of Geophysical Research-Solid Earth, 98(B8), pp. 13997-14013. https://doi.org/10.1029/93JB01159

Park, A.F., Lentz, D.R., and Thorne, K.G. 2008. Deformation and structural controls on gold mineralization in the Clarence Stream shear zone, southwestern New Brunswick, Canada. In Special Issue: Metallogeny and Setting of Gold Systems in Southern New Brunswick: Implications for Exploration in the Northern Appalachians Edited by S. Castonguay and K. G. Thorne. Exploration and Mining Geology, 17, Nos. 1-2, pp. 51-66.

Pearce, J.A., Harris, N.B.W., and Tindle, A.G. 1984. Trace element discrimination diagrams for the tectonic interpretation of granitic rocks. Journal of Petrology, 25, pp. 956-983. https://doi.org/10.1093/petrology/25.4.956

Shand, S.J. 1943. The Eruptive Rocks: their genesis, composition, and classification. John Wiley \& Sons, New York, $444 \mathrm{p}$.

Sisson, T.W. and Grove, T.L., 1993. Experimental investigations of the role of $\mathrm{H}_{2} \mathrm{O}$ in calcalkaline differentiation and subduction zone magmatism. Contributions to Mineralogy and Petrology 113, pp. 143-166.
Slama, J., Kosler, J., Condon, D.J., Crowley, J.L., Gerdes, A., Hanchar, J.M., Horstwood, M.S.A., Morris, G.A., Nasdala, L., Norberg, N., Schaltegger, U., Schoene, B., Tubrett, M.N., and Whitehouse, M.J., 2008. Plesovice zircon - A new natural reference material for $\mathrm{U}-\mathrm{Pb}$ and $\mathrm{Hf}$ isotopic microanalysis. Chemical Geology, 249(1-2), pp. 1-35. https://doi.org/10.1016/j. chemgeo.2007.11.005

Stewart, D.B., Unger, J.D., and Hutchinson, D.R. 1995. Silurian history of Penobscot Bay region, Maine. Atlantic Geology 31, pp. 67-80. https://doi. org/10.4138/2098

Stringer, P. and Burke, K.B.S. 1985. Structure in the southwest New Brunswick. In Fredericton 85, Field Excursions. Edited by R.K. Pickerill, C.K. Mawer, and L.R. Fyffe. Geological Association of Canada / Mineralogical Association of Canada, Excursion 9, 34 p.

Sun, S.-S. and McDonough, W.F. 1989. Chemical and isotopic systematics of oceanic basalts: implications for mantle composition and processes. In Magmatism in the ocean basins. Edited by A.D., Saunders and M.J. Norry. Geological Society of London Special Publication, 42, pp. 313-345. https://doi.org/10.1144/ gsl.sp.1989.042.01.19

Thorne, K.G. and Lentz, D.R. 2001. Geochemistry and petrogenesis of the East Branch Brook metagabbroic dykes in the Sawyer Brook fault zone, Clarence Stream gold prospect, southwesttern New Brunswick. Atlantic Geology 37, pp. 175-190. https://doi. org $/ 10.4138 / 1978$

Thorne, K.G., Lentz, D.R., Hall, D.C., and Yang, X. 2002. Petrology, geochemistry, and geochronology of the granitic pegmatite and aplite dykes associated with the Clarence Stream gold deposit, southwestern New Brunswick. Geological Survey of Canada, Current Research, 2002-E12, 13 p. https://doi.org/ $10.4095 / 213693$

Thorne, K.G., Lentz, D.R., Hoy, D., Fyffe, L.R., and Cabri, L.J. 2008. Characteristics of mineralization at the main zone of the Clarence Stream gold deposit, southwestern New Brunswick, Canada: Evidence for an intrusion-related gold system in the northen Appalachain orogen. In Special Issue: Metallogeny and Setting of Gold Systems in Southern New Brunswick: Implications for Exploration in the Northern Appalachians. Edited by S. Castonguay and K. G. Thorne. Exploration and Mining Geology, 17, Nos 1-2, pp. 13-49.

Thorne, K.G., Fyffe, L.R., and Creaser, R.A. 2013. ReOs geochronological constraints on the W-Mo mineralizing event in the Mount Pleasant Caldera Complex: implications for the timing of subvolcanic matism and caldera development. Atlantic Geology, 49, pp. 131-150. https://doi.org/10.4138/ atlgeol.2013.007 
van Staal, Sullivan, R.W., and Whalen, J.B. 1996. Provenance and tectonic history of the Gander Zone in the Caledonian/Appalachian orogen: Implications for the origin and assembly of Avalon. In Avalonian and Related Peri-Gondwanan Terranes of the CircumNorth Atlantic. Edited by R.D. Nance and M.D. Thompson. Geological Society of America, Special Paper 304, pp. 347-367.

van Staal, C.R., Whalen, J.B., Valverde-Vaquero, P., Zagorevski, A., and Rogers, N. 2009. Pre-Carboniferous, episodic accretion-related, orogenesis along the Laurentian margin of the northern Appalachians. In Ancient Orogens and Modern Analogues. Edited by J.B. Murphy, J.D. Keppie, and A.J. Hynes. Geological Society, London, Special Publication 327, pp. 271-316. https://doi.org/10.1144/sp327.13

Van Wagoner, N.A., Leybourne, M.I., Dadd, K.A., Baldwin, D.K., and McNeil, W. 2002. Late Silurian bimodal volcanism of southwestern New Brunswick, Canada: Products of continental extension. Geological Society of America Bulletin, 114, pp. 400-418. https://doi. org/10.1130/0016-7606(2002)114<0400:LSBVOS>2.0. $\mathrm{CO} ; 2$

Whalen, J.B. 1986. A-type granites in New Brunswick. Geological Survey of Canada, Current Research, Part A. Paper 86-1A, pp. 297-300.

Whalen J.B. 1993. Geology, petrography and geochemistry of Appalachian granites in New Brunswick and Gaspésie, Québec. Geological Survey of Canada, Bulletin 436, 124 p. https://doi.org/10.4095/183907

Whalen, J.B., Currie, K.L., and Chappell, B.W. 1987. A-type granites: geochemical characteristics, discrimination and petrogenesis. Contributions to Mineralogy and Petrology, 95, pp. 407-419. https://doi.org/10.1007/ BF00402202
Whalen, J.B., Jenner, G.A., Currie, K.L., Barr, S.M., Longstaffe, F.J., and Hegner, E. 1994. Geochemical and isotopic characteristics of granitoids of the Avalon Zone, southern New Brunswick: possible evidence for repeated delamination events. Journal of Geology, 102, pp. 269-282. https://doi.org/10.1086/629670

Whalen, J.B., Fyffe, L.R., Longstaffe, F.J., and Jenner, G.A. 1996. The position and nature of the Gander-Avalon boundary, southern New Brunswick, based on geochemical and isotopic data from granitoid rocks. Canadian Journal of Earth Sciences, 33, pp. 129-139. https://doi.org/10.1139/e96-013

Whalen, J. B., McNicoll, V. J., van Staal, C. R., Lissenberg, C. J., Longstaffe, F. J., Jenner, G.A. and van Breemen, O. 2006. Spatial, temporal and geochemical characteristics of Silurian collision-zone magmatism: An example of a rapidly evolving magmatic system related to slab breakoff. Lithos, 89, pp. 377-404. https://doi.org/10.1016/j. lithos.2005.12.011

White, C.E. and Barr, S.M. 1996. Geology of the Brookville terrane, southern New Brunswick, Canada. In Avalonian and Related Peri-Gondwanan Terranes of the Circum-North Atlantic. Edited by R.D. Nance and M.D. Thompson. Geological Society of America, Special Paper 304, pp. 133-147.

White, C.E., Barr, S.M., Reynolds, P.H., Grace, E., and McMullin, D. 2006. The Pocologan Metamorphic Suite: High pressure metamorphism in a Silurian accretionary complex in the Avalon Zone of southern New Brunswick. Canadian Mineralogist, 44, pp. 905927. https://doi.org/10.2113/gscanmin.44.4.905

Yang, X.-M., Lentz, D.R., Chi, G., and Thorne, K.G. 2008. Geochemical characteristics of gold-related grantoids in southwestern New Brunswick, Canada. Lithos, 104, pp. 355-377. https://doi.org/10.1016/j. lithos.2008.01.002 


\section{APPENDIX}

Table A1. Results for in-situ LA-ICP-MS U-Pb monazite geochronology of Sample 171-6 (Utopia Granite).

\begin{tabular}{|c|c|c|c|c|c|c|c|c|c|c|c|c|c|c|c|c|c|}
\hline \multirow[b]{2}{*}{ spot } & \multirow[b]{2}{*}{$\mathrm{C}^{*}$} & \multicolumn{5}{|c|}{ Approx. conc. (ppm) } & \multicolumn{6}{|c|}{ Final isotope ratios } & \multicolumn{5}{|c|}{ Age (Ma) } \\
\hline & & $\begin{array}{c}\mathrm{U} \\
(\mathrm{ppm})\end{array}$ & $\begin{array}{c}\text { Th } \\
(\mathrm{ppm})\end{array}$ & $\mathrm{U} / \mathrm{Th}$ & $\begin{array}{l}{ }^{204} \mathrm{~Pb} \\
(\mathrm{cps})\end{array}$ & $\begin{array}{l}{ }^{206} \mathrm{~Pb} / \\
{ }^{204} \mathrm{~Pb}\end{array}$ & $\% \mathrm{~Pb}^{\star^{\mathrm{a}}}$ & $\begin{array}{c}{ }^{207} \mathrm{~Pb} / \\
{ }^{235} \mathrm{U}\end{array}$ & $2 \sigma$ & $\begin{array}{c}{ }^{206} \mathrm{~Pb} / \\
{ }^{238} \mathrm{U}\end{array}$ & $2 \sigma$ & $\begin{array}{l}\text { err. } \\
\text { corr. }\end{array}$ & $\begin{array}{c}{ }^{207} \mathrm{~Pb} / \\
{ }^{235} \mathrm{U}\end{array}$ & $2 \sigma$ & $\begin{array}{c}{ }^{206} \mathrm{~Pb} / \\
{ }^{238} \mathrm{U}\end{array}$ & $2 \sigma$ & $\begin{array}{c}\% \\
\text { conc. }^{b}\end{array}$ \\
\hline 171-6-C9 - 4 & 1 & 1990 & 56150 & 0.04 & 99 & 44 & 56.70 & 2.150 & 0.140 & 0.040 & 0.002 & 0.465 & 1168 & 47 & 252 & 11 & 21.5 \\
\hline $171-6-\mathrm{C} 17-3$ & 1 & 1116 & 67000 & 0.02 & 90 & 45 & 60.50 & 4.940 & 0.210 & 0.102 & 0.003 & 0.651 & 1807 & 36 & 626 & 19 & 34.6 \\
\hline 171-6-C9 - 5 & 3 & 2330 & 68700 & 0.03 & 223 & 36 & 46.30 & 0.690 & 0.840 & 0.029 & 0.013 & 0.821 & 490 & 240 & 186 & 77 & 38.0 \\
\hline 171-6-C5 - 1 & 1 & 266 & 39800 & 0.01 & 19 & 69 & 79.70 & 1.670 & 0.830 & 0.062 & 0.007 & 0.035 & 997 & 140 & 385 & 40 & 38.6 \\
\hline 171-6-C9 - 3 & 1 & 704 & 64100 & 0.01 & 36 & 106 & 82.40 & 1.650 & 1.200 & 0.068 & 0.013 & 0.090 & 974 & 160 & 424 & 74 & 43.5 \\
\hline 171-6-C6 - 2 & 1 & 825 & 68700 & 0.01 & 34 & 140 & 86.20 & 1.880 & 0.210 & 0.084 & 0.002 & 0.646 & 1021 & 75 & 519 & 14 & 50.8 \\
\hline $171-6-C 4-9$ & 3 & 1058 & 60100 & 0.02 & 261 & 35 & 50.70 & 0.340 & 0.480 & 0.062 & 0.004 & 0.861 & 700 & 200 & 389 & 26 & 55.6 \\
\hline 171-6-C15 - 4 & 1 & 2726 & 52100 & 0.05 & 63 & 201 & 91.24 & 0.968 & 0.110 & 0.061 & 0.003 & 0.112 & 688 & 42 & 384 & 18 & 55.8 \\
\hline $171-6-C 9-2$ & 1 & 524 & 65500 & 0.01 & 3 & 883 & 92.00 & 1.050 & 1.200 & 0.071 & 0.012 & 0.170 & 779 & 130 & 444 & 67 & 57.0 \\
\hline $171-6-C 1-3$ & 1 & 2181 & 125500 & 0.02 & 41 & 274 & 91.21 & 1.125 & 0.100 & 0.072 & 0.001 & 0.285 & 764 & 39 & 448 & 8 & 58.6 \\
\hline 171-6-C7 - 5 & 1 & 2431 & 161300 & 0.02 & 21 & 547 & 92.00 & 1.010 & 1.200 & 0.067 & 0.011 & 0.104 & 704 & 160 & 416 & 60 & 59.1 \\
\hline 171-6-C7 - 1 & 1 & 854 & 67000 & 0.01 & 24 & 136 & 92.47 & 1.105 & 0.058 & 0.076 & 0.002 & 0.089 & 753 & 28 & 473 & 13 & 62.8 \\
\hline $171-6-\mathrm{C} 18-2$ & 1 & 779 & 58500 & 0.01 & 31 & 135 & 92.40 & 1.131 & 0.100 & 0.078 & 0.002 & 0.424 & 769 & 46 & 486 & 13 & 63.2 \\
\hline $171-6-\mathrm{C} 10-12$ & 1 & 480 & 57100 & 0.01 & 7 & 369 & 93.30 & 0.947 & 0.230 & 0.070 & 0.002 & 0.091 & 667 & 83 & 435 & 13 & 65.2 \\
\hline 171-6-C14 - 7 & 1 & 773 & 61220 & 0.01 & 18 & 219 & 92.96 & 1.014 & 0.048 & 0.075 & 0.002 & 0.145 & 714 & 24 & 467 & 9 & 65.4 \\
\hline 171-6-C10 - 9 & 1 & 1123 & 44700 & 0.03 & 2 & 2805 & 94.43 & 0.861 & 0.049 & 0.069 & 0.001 & 0.158 & 630 & 26 & 430 & 8 & 68.2 \\
\hline $171-6-C 7-6$ & 3 & 2380 & 68600 & 0.03 & 293 & 34 & 54.80 & 0.300 & 0.220 & 0.042 & 0.003 & 0.776 & 380 & 150 & 262 & 15 & 68.9 \\
\hline $171-6-\mathrm{C} 10-10$ & 1 & 1067 & 58130 & 0.02 & 14 & 378 & 94.98 & 0.798 & 0.062 & 0.068 & 0.002 & 0.169 & 595 & 35 & 424 & 9 & 71.2 \\
\hline $171-6-\mathrm{C} 10-2$ & 1 & 1880 & 65400 & 0.03 & 21 & 500 & 95.16 & 0.837 & 0.071 & 0.073 & 0.001 & 0.360 & 615 & 31 & 452 & 9 & 73.5 \\
\hline $171-6-\mathrm{C} 18-3$ & 1 & 1797 & 108400 & 0.02 & 19 & 452 & 96.63 & 0.744 & 0.024 & 0.072 & 0.001 & 0.115 & 566 & 14 & 449 & 8 & 79.4 \\
\hline 171-6-C4 - 1 & 1 & 2103 & 127300 & 0.02 & 19 & 465 & 97.25 & 0.657 & 0.034 & 0.068 & 0.001 & 0.074 & 509 & 20 & 424 & 7 & 83.3 \\
\hline $171-6-C 15-2$ & 1 & 2373 & 69300 & 0.03 & 13 & 982 & 97.44 & 0.643 & 0.047 & 0.068 & 0.001 & 0.096 & 503 & 25 & 426 & 7 & 84.6 \\
\hline $171-6-C 17-2$ & 1 & 2706 & 122200 & 0.02 & 15 & 852 & 97.62 & 0.633 & 0.039 & 0.069 & 0.001 & 0.179 & 498 & 23 & 432 & 7 & 86.6 \\
\hline $171-6-C 14-6$ & 1 & 815 & 63000 & 0.01 & -4 & -1072 & 97.80 & 0.628 & 0.037 & 0.070 & 0.001 & 0.212 & 489 & 23 & 438 & 9 & 89.7 \\
\hline $171-6-C 14-2$ & 1 & 1662 & 106900 & 0.02 & 2 & 3530 & 98.13 & 0.625 & 0.035 & 0.071 & 0.001 & 0.022 & 494 & 21 & 444 & 7 & 89.8 \\
\hline $171-6-\mathrm{C} 1-1$ & 1 & 2613 & 122500 & 0.02 & -2 & -7380 & 98.15 & 0.602 & 0.045 & 0.070 & 0.001 & 0.003 & 479 & 24 & 436 & 8 & 91.0 \\
\hline 171-6-C9 - 1 & 1 & 528 & 58400 & 0.01 & -10 & -292 & 97.90 & 0.562 & 0.490 & 0.067 & 0.005 & 0.072 & 459 & 110 & 418 & 29 & 91.1 \\
\hline $171-6-C 4-4$ & 3 & 2302 & 46700 & 0.05 & 185 & 85 & 77.40 & 0.520 & 0.960 & 0.072 & 0.025 & 0.798 & 490 & 220 & 447 & 130 & 91.2 \\
\hline $171-6-\mathrm{C} 18-4$ & 1 & 1624 & 84600 & 0.02 & 9 & 894 & 98.47 & 0.559 & 0.350 & 0.067 & 0.006 & 0.346 & 448 & 110 & 420 & 32 & 93.8 \\
\hline $171-6-\mathrm{C} 10-4$ & 1 & 2245 & 67100 & 0.03 & -10 & -1220 & 98.65 & 0.555 & 0.110 & 0.068 & 0.002 & 0.048 & 446 & 51 & 424 & 9 & 95.1 \\
\hline $171-6-C 18-5$ & 1 & 1884 & 86300 & 0.02 & -6 & -1498 & 98.55 & 0.556 & 0.032 & 0.068 & 0.001 & 0.062 & 445 & 20 & 424 & 6 & 95.3 \\
\hline $171-6-\mathrm{C} 10-8$ & 1 & 1230 & 55250 & 0.02 & -17 & -374 & 99.23 & 0.518 & 0.033 & 0.066 & 0.001 & 0.129 & 428 & 21 & 413 & 8 & 96.6 \\
\hline $171-6-C 7-3$ & 1 & 8810 & 7260 & 1.21 & 10 & 4635 & 99.44 & 0.535 & 0.012 & 0.069 & 0.001 & 0.319 & 435 & 8 & 431 & 5 & 99.1 \\
\hline $171-6-\mathrm{C} 10-5$ & 1 & 8480 & 7220 & 1.17 & -7 & -6338 & 99.62 & 0.521 & 0.010 & 0.068 & 0.001 & 0.282 & 426 & 7 & 423 & 4 & 99.4 \\
\hline 171-6-C4- 7 & 1 & 513.3 & 52660 & 0.01 & -7 & -390 & 99.26 & 0.502 & 0.037 & 0.067 & 0.002 & 0.074 & 421 & 25 & 420 & 10 & 99.8 \\
\hline $171-6-C 10-1$ & 1 & 2193 & 85600 & 0.03 & -3 & -3803 & 99.42 & 0.517 & 0.020 & 0.068 & 0.001 & 0.015 & 421 & 13 & 421 & 6 & 100.0 \\
\hline $171-6-C 5-3$ & 1 & 370.6 & 44700 & 0.01 & 2 & 1069 & 98.68 & 0.516 & 0.059 & 0.067 & 0.002 & 0.199 & 419 & 38 & 420 & 13 & 100.2 \\
\hline 171-6-C15 - 1 & 1 & 2285 & 53200 & 0.04 & 2 & 6075 & 99.19 & 0.522 & 0.120 & 0.069 & 0.002 & 0.005 & 427 & 50 & 428 & 9 & 100.3 \\
\hline $171-6-C 10-7$ & 1 & 8740 & 7340 & 1.19 & -13 & -3582 & 99.78 & 0.525 & 0.010 & 0.069 & 0.001 & 0.402 & 428 & 7 & 430 & 5 & 100.6 \\
\hline $171-6-C 5-4$ & 1 & 397.1 & 44970 & 0.01 & -4 & -569 & 99.37 & 0.522 & 0.280 & 0.068 & 0.004 & 0.138 & 418 & 85 & 421 & 22 & 100.7 \\
\hline $171-6-C 6-1$ & 1 & 710 & 62600 & 0.01 & -7 & -581 & 99.49 & 0.506 & 0.350 & 0.067 & 0.004 & 0.149 & 417 & 120 & 421 & 21 & 101.0 \\
\hline $171-6-C 6-3$ & 1 & 897 & 57180 & 0.02 & -8 & -598 & 99.36 & 0.510 & 0.031 & 0.068 & 0.001 & 0.094 & 418 & 21 & 423 & 9 & 101.1 \\
\hline $171-6-C 5-2$ & 1 & 379.5 & 43110 & 0.01 & 4 & 521 & 99.53 & 0.503 & 0.045 & 0.067 & 0.002 & 0.084 & 411 & 30 & 417 & 10 & 101.5 \\
\hline $171-6-C 4-8$ & 1 & 565.8 & 58300 & 0.01 & 5 & 659 & 99.44 & 0.509 & 0.370 & 0.068 & 0.004 & 0.059 & 419 & 120 & 426 & 24 & 101.7 \\
\hline $171-6-\mathrm{C} 10-3$ & 1 & 2346 & 41100 & 0.06 & 1 & 12570 & 99.52 & 0.501 & 0.019 & 0.068 & 0.001 & 0.141 & 414 & 13 & 422 & 6 & 102.0 \\
\hline $171-6-\mathrm{C} 10-6$ & 1 & 8440 & 6970 & 1.21 & -9 & -4889 & 99.81 & 0.526 & 0.011 & 0.070 & 0.001 & 0.237 & 428 & 8 & 437 & 4 & 102.1 \\
\hline
\end{tabular}


Table A1. Continued.

\begin{tabular}{|c|c|c|c|c|c|c|c|c|c|c|c|c|c|c|c|c|c|}
\hline \multirow[b]{2}{*}{ spot } & \multirow[b]{2}{*}{$\mathrm{C}^{*}$} & \multicolumn{5}{|c|}{ Approx. conc. (ppm) } & \multicolumn{6}{|c|}{ Final isotope ratios } & \multicolumn{5}{|c|}{ Age (Ma) } \\
\hline & & $\begin{array}{c}\mathrm{U} \\
(\mathrm{ppm})\end{array}$ & $\begin{array}{c}\text { Th } \\
(\mathrm{ppm})\end{array}$ & $\mathrm{U} / \mathrm{Th}$ & $\begin{array}{l}{ }^{204} \mathrm{~Pb} \\
(\mathrm{cps})\end{array}$ & $\begin{array}{l}{ }^{206} \mathrm{~Pb} / \\
{ }^{204} \mathrm{~Pb}\end{array}$ & $\% \mathrm{~Pb}^{*^{\mathrm{a}}}$ & $\begin{array}{c}{ }^{207} \mathrm{~Pb} / \\
{ }^{235} \mathrm{U}\end{array}$ & $2 \sigma$ & ${ }^{206} \mathrm{~Pb} /$ & $2 \sigma$ & $\begin{array}{l}\text { err. } \\
\text { corr. }\end{array}$ & $\begin{array}{c}{ }^{207} \mathrm{~Pb} / \\
{ }^{235} \mathrm{U}\end{array}$ & $2 \sigma$ & ${ }^{206} \mathrm{~Pb} /$ & $2 \sigma$ & $\begin{array}{c}\% \\
\text { conc. }^{\mathrm{b}}\end{array}$ \\
\hline 171-6-C10- 11 & 1 & 552 & 61300 & 0.01 & 0 & - & 99.17 & 0.525 & 0.360 & 0.071 & 0.003 & 0.190 & 429 & 120 & 440 & 18 & 102.6 \\
\hline 171-6-C17 - 1 & 1 & 2037 & 61650 & 0.03 & -8 & -1286 & 99.50 & 0.496 & 0.017 & 0.068 & 0.001 & 0.003 & 411 & 12 & 422 & 7 & 102.7 \\
\hline 171-6-C7 - 4 & 1 & 12770 & 11030 & 1.16 & 19 & 3511 & 99.93 & 0.500 & 0.009 & 0.068 & 0.001 & 0.412 & 411 & 6 & 423 & 5 & 102.9 \\
\hline 171-6-C14- 1 & 1 & 1031 & 71800 & 0.01 & -2 & -3331 & 99.36 & 0.508 & 0.036 & 0.069 & 0.001 & 0.098 & 416 & 23 & 429 & 8 & 103.1 \\
\hline 171-6-C1 - 2 & 3 & 2172 & 128300 & 0.02 & 135 & 85 & 78.08 & 0.490 & 0.210 & 0.065 & 0.002 & 0.823 & 390 & 150 & 403 & 12 & 103.3 \\
\hline 171-6-C7 - 2 & 1 & 1308 & 63900 & 0.02 & 15 & 474 & 99.66 & 0.505 & 0.024 & 0.069 & 0.001 & 0.167 & 414 & 16 & 428 & 7 & 103.4 \\
\hline 171-6-C18- 1 & 1 & 2161 & 137400 & 0.02 & 2 & 5671 & 99.48 & 0.506 & 0.020 & 0.069 & 0.001 & 0.044 & 414 & 13 & 429 & 5 & 103.7 \\
\hline $171-6-C 4-3$ & 1 & 1709 & 121400 & 0.01 & -2 & -4745 & 99.57 & 0.490 & 0.018 & 0.068 & 0.001 & 0.063 & 408 & 13 & 424 & 6 & 103.8 \\
\hline $171-6-C 4-12$ & 1 & 517 & 53090 & 0.01 & 10 & 287 & 99.42 & 0.511 & 0.040 & 0.069 & 0.002 & 0.146 & 411 & 27 & 428 & 11 & 104.1 \\
\hline $171-6-C 4-2$ & 1 & 1594 & 110200 & 0.01 & -3 & -2977 & 99.63 & 0.506 & 0.021 & 0.069 & 0.001 & 0.055 & 413 & 14 & 430 & 7 & 104.2 \\
\hline $171-6-C 5-5$ & 1 & 1325 & 103400 & 0.01 & -4 & -1618 & 99.41 & 0.527 & 0.022 & 0.072 & 0.001 & 0.097 & 431 & 15 & 450 & 7 & 104.5 \\
\hline $171-6-C 15-3$ & 1 & 2317 & 83700 & 0.03 & 2 & 7072 & 99.76 & 0.501 & 0.190 & 0.070 & 0.003 & 0.082 & 411 & 71 & 436 & 18 & 106.0 \\
\hline $171-6-C 4-13$ & 1 & 802 & 67800 & 0.01 & -4 & -1151 & 99.46 & 0.484 & 0.028 & 0.068 & 0.002 & 0.112 & 399 & 20 & 424 & 10 & 106.3 \\
\hline
\end{tabular}

Notes: $\mathrm{C}^{\star}=$ Common $\mathrm{Pb}$ correction (1-uncorrected for common- $\mathrm{Pb}$; 2-common-Pb corrected using Andersen (2002) method; 3-common- $\mathrm{Pb}$ corrected using the measured $\left.{ }^{204} \mathrm{~Pb}\right)$. ${ }^{\mathrm{a}}$ calculated from Andersen (2002) method; ${ }^{\mathrm{b}}$ calculated as $100 \times\left({ }^{206} \mathrm{~Pb} /{ }^{238} \mathrm{U}\right.$ age ${ }^{207} \mathrm{~Pb} /{ }^{235} \mathrm{U}$ age). Samples numbers in bold and italic are used in final age calculations.

Table A2. Results for in-situ LA-ICP-MS U-Pb zircon geochronology of Sample 15-87 (Utopia Granite).

\begin{tabular}{|c|c|c|c|c|c|c|c|c|c|c|c|c|c|c|c|c|c|}
\hline \multirow[b]{2}{*}{ spot } & \multirow[b]{2}{*}{$\mathrm{C}^{*}$} & \multicolumn{5}{|c|}{ Approx. conc. (ppm) } & \multicolumn{6}{|c|}{ Final isotope ratios } & \multicolumn{4}{|c|}{ Age (Ma) } & \multirow[b]{2}{*}{$\begin{array}{c}\% \\
\text { conc. }^{\mathrm{b}}\end{array}$} \\
\hline & & $\begin{array}{c}\mathrm{U} \\
(\mathrm{ppm})\end{array}$ & $\begin{array}{c}\text { Th } \\
(\mathrm{ppm})\end{array}$ & $\mathrm{U} / \mathrm{Th}$ & $\begin{array}{l}{ }^{204} \mathrm{~Pb} \\
(\mathrm{cps})\end{array}$ & $\begin{array}{l}{ }^{206} \mathrm{~Pb} / \\
{ }^{204} \mathrm{~Pb}\end{array}$ & $\% \mathrm{~Pb}^{*^{\mathrm{a}}}$ & $\begin{array}{c}{ }^{207} \mathrm{~Pb} / \\
{ }^{235} \mathrm{U}\end{array}$ & $2 \sigma$ & $\begin{array}{l}{ }^{206} \mathrm{~Pb} / \\
{ }^{238} \mathrm{U}\end{array}$ & $2 \sigma$ & $\begin{array}{c}\text { err. } \\
\text { corr. }\end{array}$ & $\begin{array}{c}{ }^{207} \mathrm{~Pb} / \\
{ }^{235} \mathrm{U}\end{array}$ & $2 \sigma$ & $\begin{array}{c}{ }^{206} \mathrm{~Pb} / \\
{ }^{238} \mathrm{U}\end{array}$ & $2 \sigma$ & \\
\hline $15-87-03-28$ & 3 & 3305 & 2090 & 1.58 & 5500 & 49 & 77.20 & 2.370 & 0.140 & 0.0816 & 0.0017 & 0.871 & 1226 & 40 & 506 & 10 & 41.3 \\
\hline $15-87-03-28$ & 3 & 3305 & 2090 & 1.58 & 5500 & 49 & 77.20 & 2.370 & 0.140 & 0.0816 & 0.0017 & 0.871 & 1226 & 40 & 506 & 10 & 41.3 \\
\hline $15-87-5-C 4-2-204$ & 3 & 42200 & 881000 & 0.05 & 235 & 1047 & 98.37 & 1.459 & 0.052 & 0.0702 & 0.0012 & 0.330 & 912 & 21 & 437 & 7 & 47.9 \\
\hline $15-87-5-C 4-2-204$ & 3 & 42200 & 881000 & 0.05 & 235 & 1047 & 98.37 & 1.459 & 0.052 & 0.0702 & 0.0012 & 0.330 & 912 & 21 & 437 & 7 & 47.9 \\
\hline $15-87-03-30$ & 2 & 1463 & 1980 & 0.74 & 7 & 5514 & 99.45 & 1.270 & 0.069 & 0.0684 & 0.0014 & 0.485 & 830 & 30 & 427 & 8 & 51.4 \\
\hline $15-87-03-30$ & 2 & 1463 & 1980 & 0.74 & 7 & 5514 & 99.45 & 1.270 & 0.069 & 0.0684 & 0.0014 & 0.485 & 830 & 30 & 427 & 8 & 51.4 \\
\hline $87-3-11-204$ & 3 & 2626 & 20900 & 0.13 & 54 & 1462 & 98.89 & 1.324 & 0.061 & 0.0737 & 0.0015 & 0.474 & 854 & 27 & 458 & 9 & 53.7 \\
\hline $87-3-11-204$ & 3 & 2626 & 20900 & 0.13 & 54 & 1462 & 98.89 & 1.324 & 0.061 & 0.0737 & 0.0015 & 0.474 & 854 & 27 & 458 & 9 & 53.7 \\
\hline $15-87-3-7-204$ & 2 & 2441 & 1556 & 1.57 & 129 & 855 & 97.50 & 1.107 & 0.032 & 0.0687 & 0.0010 & 0.018 & 756 & 15 & 429 & 6 & 56.7 \\
\hline $15-87-3-7-204$ & 2 & 2441 & 1556 & 1.57 & 129 & 855 & 97.50 & 1.107 & 0.032 & 0.0687 & 0.0010 & 0.018 & 756 & 15 & 429 & 6 & 56.7 \\
\hline $15-87-03-23$ & 1 & 3260 & 1200 & 2.72 & 38 & 5026 & 99.42 & 1.085 & 0.040 & 0.0680 & 0.0011 & 0.575 & 744 & 20 & 424 & 7 & 57.0 \\
\hline $15-87-03-16$ & 3 & 545.5 & 1550 & 0.35 & 25 & 1324 & 98.72 & 1.154 & 0.050 & 0.0713 & 0.0014 & 0.389 & 777 & 24 & 444 & 8 & 57.2 \\
\hline $15-87-5-C 2-2-204$ & 3 & 1005 & 169.7 & 5.92 & 127 & 1632 & 98.79 & 0.949 & 0.036 & 0.0623 & 0.0011 & 0.227 & 676 & 19 & 390 & 7 & 57.6 \\
\hline 15-87-4-D - 9-204 & 1 & 935 & 479 & 1.95 & 156 & 1592 & 99.10 & 1.080 & 0.041 & 0.0705 & 0.0012 & 0.265 & 746 & 22 & 439 & 7 & 58.9 \\
\hline $15-87-3-3-204$ & 1 & 945 & 1200 & 0.79 & 12 & 1593 & 99.26 & 0.633 & 0.023 & 0.0506 & 0.0008 & 0.506 & 499 & 14 & 318 & 5 & 63.7 \\
\hline 15-87-4-D - 7-204 & 1 & 14880 & 671 & 22.18 & 56 & 4623 & 99.51 & 0.498 & 0.016 & 0.0467 & 0.0008 & 0.585 & 410 & 11 & 295 & 5 & 71.9 \\
\hline $15-87-4-\mathrm{D}-11-204$ & 2 & 4540 & 2126 & 2.14 & 29 & 3814 & 99.39 & 0.830 & 0.023 & 0.0724 & 0.0012 & 0.438 & 614 & 13 & 451 & 7 & 73.4 \\
\hline $15-87-5-C 1-2-204$ & 2 & 2360 & 792 & 2.98 & 40 & 1084 & 98.14 & 0.689 & 0.024 & 0.0638 & 0.0010 & 0.396 & 532 & 14 & 398 & 6 & 74.9 \\
\hline $15-87-3-13-204$ & 3 & 2499 & 2277 & 1.10 & 100 & 792 & 97.87 & 0.704 & 0.019 & 0.0684 & 0.0009 & 0.707 & 541 & 11 & 427 & 6 & 78.9 \\
\hline $15-87-03-22$ & 2 & 4961 & 1511 & 3.28 & 361 & 229 & 92.36 & 0.705 & 0.018 & 0.0694 & 0.0011 & 0.504 & 542 & 11 & 433 & 7 & 79.9 \\
\hline $15-87-3-9-204$ & 1 & 2110 & 2059 & 1.02 & 74 & 997 & 98.02 & 0.663 & 0.021 & 0.0664 & 0.0011 & 0.476 & 516 & 13 & 415 & 7 & 80.3 \\
\hline $15-87-3-14-204$ & 3 & 2036 & 1080 & 1.89 & 46 & 5443 & 99.66 & 0.656 & 0.026 & 0.0666 & 0.0014 & 0.320 & 512 & 16 & 416 & 8 & 81.2 \\
\hline $15-87-3-10-204$ & 1 & 2672 & 7080 & 0.38 & 368 & 206 & 90.83 & 0.638 & 0.020 & 0.0655 & 0.0010 & 0.420 & 502 & 13 & 409 & 6 & 81.5 \\
\hline $15-87-4-\mathrm{D}-14-204$ & 1 & 5933 & 2060 & 2.88 & 29 & 2521 & 99.14 & 0.619 & 0.018 & 0.0654 & 0.0010 & 0.644 & 489 & 11 & 408 & 6 & 83.5 \\
\hline
\end{tabular}


Table A2. Continued.

\begin{tabular}{|c|c|c|c|c|c|c|c|c|c|c|c|c|c|c|c|c|c|}
\hline \multirow[b]{2}{*}{ spot } & \multirow[b]{2}{*}{$\mathrm{C}^{*}$} & \multicolumn{5}{|c|}{ Approx. conc. (ppm) } & \multicolumn{6}{|c|}{ Final isotope ratios } & \multicolumn{5}{|c|}{ Age (Ma) } \\
\hline & & $\begin{array}{c}\mathrm{U} \\
(\mathrm{ppm})\end{array}$ & $\begin{array}{c}\text { Th } \\
(\mathrm{ppm})\end{array}$ & $\mathrm{U} / \mathrm{Th}$ & $\begin{array}{l}{ }^{204} \mathrm{~Pb} \\
(\mathrm{cps})\end{array}$ & $\begin{array}{l}{ }^{206} \mathrm{~Pb} / \\
{ }^{204} \mathrm{~Pb}\end{array}$ & $\% \mathrm{~Pb}^{\star^{\mathrm{a}}}$ & $\begin{array}{c}{ }^{207} \mathrm{~Pb} / \\
{ }^{235} \mathrm{U}\end{array}$ & $2 \sigma$ & $\begin{array}{c}{ }^{206} \mathrm{~Pb} / \\
{ }^{238} \mathrm{U}\end{array}$ & $2 \sigma$ & $\begin{array}{l}\text { err. } \\
\text { corr. }\end{array}$ & $\begin{array}{l}{ }^{207} \mathrm{~Pb} / \\
{ }^{235} \mathrm{U}\end{array}$ & $2 \sigma$ & $\begin{array}{c}{ }^{206} \mathrm{~Pb} / \\
{ }^{238} \mathrm{U}\end{array}$ & $2 \sigma$ & $\begin{array}{c}\% \\
\text { conc. }\end{array}$ \\
\hline $15-87-5-C 4-1$ & 1 & 1386 & 22210 & 0.06 & 767 & 150 & 88.31 & 0.655 & 0.024 & 0.0689 & 0.0012 & 0.159 & 511 & 15 & 429 & 7 & 84.0 \\
\hline $15-87-5-1-204$ & 3 & 7190 & 4240 & 1.70 & -4 & -20400 & 99.64 & 0.614 & 0.016 & 0.0653 & 0.0009 & 0.227 & 486 & 10 & 408 & 5 & 84.0 \\
\hline $15-87-5-9-204$ & 2 & 4210 & 2259 & 1.86 & -27 & -1716 & 99.86 & 0.598 & 0.016 & 0.0645 & 0.0009 & 0.544 & 476 & 10 & 403 & 6 & 84.7 \\
\hline $15-87-03-17$ & 2 & 890 & 530 & 1.68 & 60 & 2778 & 99.43 & 0.613 & 0.023 & 0.0677 & 0.0010 & 0.321 & 486 & 15 & 422 & 6 & 86.9 \\
\hline $15-87-5-C 2-4$ & 3 & 2498 & 573 & 4.36 & 70 & 2280 & 99.37 & 0.550 & 0.017 & 0.0624 & 0.0009 & 0.075 & 445 & 11 & 390 & 5 & 87.7 \\
\hline $15-87-03-12$ & 2 & 1954 & 3030 & 0.64 & 115 & 836 & 97.58 & 0.586 & 0.019 & 0.0662 & 0.0010 & 0.357 & 468 & 12 & 413 & 6 & 88.3 \\
\hline $15-87-5-C 2-3-204$ & 3 & 5960 & 423 & 14.09 & 48 & 1915 & 98.76 & 0.548 & 0.016 & 0.0628 & 0.0013 & 0.836 & 444 & 10 & 393 & 8 & 88.5 \\
\hline $15-87-03-06$ & 2 & 1467 & 1573 & 0.93 & 320 & 231 & 92.21 & 0.609 & 0.020 & 0.0689 & 0.0010 & 0.247 & 482 & 12 & 429 & 6 & 89.0 \\
\hline $15-87-03-25$ & 3 & 12980 & 1219 & 10.65 & 51 & 2396 & 99.14 & 0.440 & 0.013 & 0.0525 & 0.0009 & 0.591 & 370 & 9 & 330 & 6 & 89.2 \\
\hline 15-87-4-D - 10-204 & 1 & 6637 & 1272 & 5.22 & 327 & 505 & 96.42 & 0.562 & 0.015 & 0.0654 & 0.0008 & 0.344 & 453 & 10 & 408 & 5 & 90.2 \\
\hline $15-87-03-20$ & 2 & 6100 & 700 & 8.71 & -2 & -6425 & 99.78 & 0.519 & 0.014 & 0.0614 & 0.0012 & 0.786 & 424 & 10 & 384 & 7 & 90.4 \\
\hline $15-87-5-\mathrm{C} 1-1$ & 1 & 1963 & 1326 & 1.48 & 144 & 620 & 96.95 & 0.549 & 0.016 & 0.0644 & 0.0008 & 0.341 & 444 & 10 & 402 & 5 & 90.5 \\
\hline $15-87-05-06$ & 3 & 3953 & 1269 & 3.12 & 17 & 11835 & 99.77 & 0.571 & 0.016 & 0.0667 & 0.0010 & 0.680 & 458 & 10 & 416 & 6 & 90.7 \\
\hline $15-87-03-05$ & 1 & 612.2 & 779 & 0.79 & 31 & 1926 & 98.84 & 0.571 & 0.021 & 0.0674 & 0.0010 & 0.004 & 458 & 13 & 421 & 6 & 91.8 \\
\hline $15-87-03-26$ & 3 & 3317 & 633 & 5.24 & 5 & 3662 & 99.27 & 0.539 & 0.015 & 0.0644 & 0.0010 & 0.115 & 438 & 10 & 402 & 6 & 91.9 \\
\hline $15-87-03-27$ & 2 & 495 & 527.1 & 0.94 & 1404 & 97 & 81.00 & 0.529 & 0.019 & 0.0639 & 0.0009 & 0.316 & 431 & 13 & 399 & 6 & 92.5 \\
\hline $15-87-3-1-204$ & 1 & 4121 & 2301 & 1.79 & 203 & 1255 & 98.43 & 0.563 & 0.015 & 0.0679 & 0.0011 & 0.718 & 454 & 10 & 423 & 6 & 93.3 \\
\hline $15-87-05-05$ & 3 & 1193 & 756 & 1.58 & 59 & 2366 & 99.19 & 0.571 & 0.017 & 0.0685 & 0.0010 & 0.521 & 458 & 11 & 427 & 6 & 93.3 \\
\hline $15-87-4-D-12$ & 1 & 2964 & 652 & 4.55 & -11 & -1789 & 99.64 & 0.530 & 0.014 & 0.0644 & 0.0007 & 0.203 & 431 & 9 & 403 & 4 & 93.4 \\
\hline $15-87-3-18-204$ & 3 & 5490 & 4930 & 1.11 & 44 & 4193 & 99.45 & 0.544 & 0.014 & 0.0662 & 0.0008 & 0.406 & 441 & 9 & 413 & 5 & 93.7 \\
\hline $15-87-03-04$ & 2 & 666 & 634 & 1.05 & 24 & 963 & 99.08 & 0.581 & 0.021 & 0.0698 & 0.0011 & 0.260 & 464 & 14 & 435 & 7 & 93.7 \\
\hline 15-87-03-19 & 3 & 5210 & 8260 & 0.63 & 103 & 2034 & 99.12 & 0.540 & 0.014 & 0.0660 & 0.0008 & 0.442 & 438 & 9 & 412 & 5 & 94.0 \\
\hline $15-87-03-24$ & 3 & 5400 & 1090 & 4.95 & 138 & 2714 & 99.06 & 0.496 & 0.014 & 0.0613 & 0.0013 & 0.578 & 409 & 10 & 385 & 7 & 94.1 \\
\hline $15-87-4-\mathrm{D}-6$ & 3 & 1664 & 425 & 3.92 & 833 & 522 & 96.84 & 0.533 & 0.017 & 0.0658 & 0.0010 & 0.345 & 433 & 11 & 411 & 6 & 94.7 \\
\hline $15-87-4-\mathrm{D}-8$ & 1 & 6810 & 2032 & 3.35 & 162 & 246 & 92.92 & 0.509 & 0.014 & 0.0633 & 0.0010 & 0.514 & 418 & 9 & 396 & 6 & 94.8 \\
\hline $15-87-05-02$ & 1 & 2724 & 1396 & 1.95 & -1 & -52270 & 99.77 & 0.525 & 0.015 & 0.0659 & 0.0012 & 0.536 & 428 & 10 & 411 & 7 & 96.1 \\
\hline $15-87-03-15$ & 3 & 6895 & 723 & 9.54 & 1 & 20460 & 99.70 & 0.510 & 0.013 & 0.0644 & 0.0007 & 0.586 & 419 & 9 & 403 & 5 & 96.2 \\
\hline $15-87-2-C 1-1$ & 1 & 4442 & 572 & 7.77 & -2 & -78700 & 99.76 & 0.512 & 0.015 & 0.0666 & 0.0014 & 0.289 & 420 & 10 & 416 & 9 & 99.0 \\
\hline $15-87-4-D-13$ & 1 & 510.3 & 75.9 & 6.72 & 177 & 1200 & 98.31 & 0.525 & 0.020 & 0.0681 & 0.0014 & 0.079 & 428 & 13 & 425 & 8 & 99.2 \\
\hline $15-87-05-03$ & 2 & 1292 & 118.4 & 10.91 & -8 & -6911 & 99.85 & 0.513 & 0.015 & 0.0671 & 0.0009 & 0.059 & 420 & 10 & 419 & 5 & 99.7 \\
\hline $15-87-2-C 2-3$ & 1 & 3914 & 453 & 8.64 & 7 & 6114 & 99.60 & 0.512 & 0.015 & 0.0671 & 0.0014 & 0.174 & 419 & 10 & 419 & 9 & 99.8 \\
\hline $15-87-2-C 2-2$ & 1 & 3721 & 319.3 & 11.65 & 34 & 3053 & 99.80 & 0.507 & 0.014 & 0.0670 & 0.0014 & 0.396 & 417 & 10 & 418 & 8 & 100.1 \\
\hline $15-87-05-04$ & 3 & 1370 & 110.9 & 12.35 & 21 & 2295 & 99.35 & 0.513 & 0.015 & 0.0679 & 0.0009 & 0.340 & 420 & 10 & 423 & 5 & 100.7 \\
\hline $15-87-5-C 2-1$ & 3 & 1105 & 216.9 & 5.09 & 131 & 279 & 93.08 & 0.520 & 0.018 & 0.0694 & 0.0011 & 0.470 & 425 & 12 & 432 & 7 & 101.8 \\
\hline $15-87-03-21$ & 1 & 333.8 & 607.9 & 0.55 & 204 & 809 & 97.76 & 0.502 & 0.021 & 0.0675 & 0.0010 & 0.340 & 412 & 14 & 421 & 6 & 102.2 \\
\hline
\end{tabular}

Notes: $\mathrm{C}^{*}=$ Common $\mathrm{Pb}$ correction (1-uncorrected for common- $\mathrm{Pb}$; 2-common-Pb corrected using Andersen (2002) method; 3-common- $\mathrm{Pb}$ corrected using the measured ${ }^{204} \mathrm{~Pb}$ ). ${ }^{\mathrm{a}}$ calculated from Andersen (2002) method; ${ }^{\mathrm{b}}$ calculated as $100 \times\left({ }^{206} \mathrm{~Pb} /{ }^{238} \mathrm{U}\right.$ age $/{ }^{207} \mathrm{~Pb} /{ }^{235} \mathrm{U}$ age $)$. Samples numbers in bold and italic are used in final age calculations. 
Table A3. Results for in-situ LA-ICP-MS U-Pb zircon geochronology of sample 15-104 (Utopia Granite).

\begin{tabular}{|c|c|c|c|c|c|c|c|c|c|c|c|c|c|c|c|c|c|}
\hline \multirow[b]{2}{*}{ spot } & \multirow[b]{2}{*}{$\mathrm{C}^{*}$} & \multicolumn{5}{|c|}{ Approx. conc. (ppm) } & \multicolumn{6}{|c|}{ Final isotope ratios } & \multicolumn{5}{|c|}{ Age (Ma) } \\
\hline & & $\begin{array}{c}\mathrm{U} \\
(\mathrm{ppm})\end{array}$ & $\begin{array}{c}\text { Th } \\
(\mathrm{ppm})\end{array}$ & $\mathrm{U} / \mathrm{Th}$ & $\begin{array}{l}{ }^{204} \mathrm{~Pb} \\
(\mathrm{cps})\end{array}$ & $\begin{array}{l}{ }^{206} \mathrm{~Pb} / \\
{ }^{204} \mathrm{~Pb}\end{array}$ & $\% \mathrm{~Pb}^{{ }^{\mathrm{a}}}$ & $\begin{array}{c}{ }^{207} \mathrm{~Pb} / \\
{ }^{235} \mathrm{U}\end{array}$ & $2 \sigma$ & $\begin{array}{c}{ }^{206} \mathrm{~Pb} / \\
{ }^{238} \mathrm{U}\end{array}$ & $2 \sigma$ & $\begin{array}{l}\text { err. } \\
\text { corr. }\end{array}$ & $\begin{array}{c}{ }^{207} \mathrm{~Pb} / \\
{ }^{235} \mathrm{U}\end{array}$ & $2 \sigma$ & $\begin{array}{c}{ }^{206} \mathrm{~Pb} / \\
{ }^{238} \mathrm{U}\end{array}$ & $2 \sigma$ & $\begin{array}{c}\% \\
\text { conc. }\end{array}$ \\
\hline 104-3-C7 - 1 & 1 & 751 & 767 & 0.98 & 89 & 199 & 92.24 & 1.824 & 0.071 & 0.1058 & 0.0029 & 0.753 & 1049 & 25 & 650 & 18 & 62.0 \\
\hline $104-1-\mathrm{C} 1-2$ & 1 & 1071 & 591.1 & 1.81 & 84 & 319 & 94.13 & 0.891 & 0.063 & 0.0637 & 0.0015 & 0.439 & 636 & 33 & 398 & 9 & 62.6 \\
\hline $104-3-C 7-3$ & 1 & 1268 & 928 & 1.37 & 86 & 377 & 95.60 & 1.054 & 0.075 & 0.0827 & 0.0030 & 0.142 & 730 & 31 & 512 & 18 & 70.2 \\
\hline $104-3-C 4-2$ & 3 & 2641 & 2954 & 0.89 & 1417 & 45 & 64.70 & 1.550 & 0.340 & 0.1057 & 0.0070 & 0.776 & 880 & 120 & 645 & 40 & 73.3 \\
\hline $104-1-\mathrm{C} 11-2$ & 1 & 1127 & 1033 & 1.09 & 72 & 528 & 96.81 & 0.722 & 0.021 & 0.0657 & 0.0014 & 0.113 & 553 & 13 & 410 & 9 & 74.2 \\
\hline 104-1-C6 - 1 & 3 & 3340 & 2780 & 1.20 & 3110 & 31 & 58.49 & 1.580 & 0.320 & 0.1096 & 0.0044 & 0.760 & 880 & 130 & 669 & 25 & 76.0 \\
\hline $104-1-\mathrm{C} 1-6$ & 3 & 4390 & 1428 & 3.07 & 1124 & 40 & 52.66 & 0.400 & 0.130 & 0.0360 & 0.0019 & 0.694 & 298 & 93 & 228 & 12 & 76.5 \\
\hline $104-2-\mathrm{C} 8-1$ & 3 & 4707 & 2592 & 1.82 & 4090 & 33 & 58.20 & 1.350 & 0.220 & 0.1111 & 0.0036 & 0.700 & 812 & 100 & 679 & 21 & 83.6 \\
\hline $104-2-C 5-4$ & 1 & 1726 & 991 & 1.74 & 40 & 1460 & 98.14 & 0.665 & 0.033 & 0.0695 & 0.0016 & 0.701 & 517 & 20 & 433 & 10 & 83.7 \\
\hline $104-1-\mathrm{C} 1-5$ & 1 & 5100 & 2549 & 2.00 & 96 & 1178 & 98.37 & 0.584 & 0.054 & 0.0630 & 0.0020 & 0.812 & 466 & 32 & 393 & 12 & 84.3 \\
\hline $104-1-C 5-4$ & 1 & 2893 & 1432 & 2.02 & 84 & 993 & 98.39 & 0.621 & 0.017 & 0.0665 & 0.0014 & 0.201 & 490 & 11 & 415 & 9 & 84.7 \\
\hline $104-1-\mathrm{C} 1-4$ & 3 & 2249 & 859 & 2.62 & 631 & 86 & 76.60 & 0.449 & 0.070 & 0.0505 & 0.0024 & 0.391 & 370 & 52 & 318 & 15 & 85.9 \\
\hline $104-1-\mathrm{C} 6-3$ & 3 & 4880 & 3400 & 1.44 & 309 & 263 & 92.04 & 0.543 & 0.042 & 0.0614 & 0.0013 & 0.583 & 444 & 29 & 384 & 8 & 86.5 \\
\hline $104-1-\mathrm{C} 1-1$ & 1 & 2770 & 1544 & 1.79 & 55 & 1287 & 98.66 & 0.592 & 0.062 & 0.0654 & 0.0015 & 0.456 & 472 & 32 & 409 & 9 & 86.6 \\
\hline $104-2-\mathrm{C} 2-3$ & 1 & 1090 & 527 & 2.07 & 22 & 1405 & 98.79 & 0.569 & 0.019 & 0.0644 & 0.0014 & 0.031 & 457 & 12 & 402 & 8 & 88.1 \\
\hline $104-1-C 4-3$ & 3 & 4016 & 3860 & 1.04 & 556 & 137 & 85.39 & 0.345 & 0.050 & 0.0420 & 0.0015 & 0.377 & 297 & 36 & 265 & 9 & 89.3 \\
\hline $104-2-C 5-3$ & 3 & 1113 & 715 & 1.56 & 1302 & 45 & 62.60 & 1.050 & 0.270 & 0.1060 & 0.0070 & 0.710 & 720 & 130 & 647 & 40 & 89.9 \\
\hline $104-3-C 7-2$ & 1 & 1065 & 867 & 1.23 & 18 & 1248 & 98.94 & 0.628 & 0.026 & 0.0714 & 0.0018 & 0.193 & 494 & 16 & 445 & 11 & 90.0 \\
\hline $104-1-C 4-1$ & 1 & 1402 & 1090 & 1.29 & 14 & 3238 & 98.99 & 0.577 & 0.017 & 0.0666 & 0.0016 & 0.467 & 462 & 11 & 415 & 10 & 90.0 \\
\hline $104-1-C 3-6$ & 3 & 7680 & 9620 & 0.80 & 2501 & 74 & 74.96 & 0.623 & 0.087 & 0.0691 & 0.0015 & 0.447 & 476 & 52 & 431 & 9 & 90.5 \\
\hline $104-1-\mathrm{C} 3-8$ & 3 & 1595 & 1187 & 1.34 & 240 & 227 & 91.31 & 0.586 & 0.100 & 0.0672 & 0.0016 & 0.588 & 458 & 64 & 419 & 10 & 91.5 \\
\hline $104-3-C 2-3$ & 3 & 2268 & 1334 & 1.70 & 1760 & 59 & 69.60 & 0.633 & 0.089 & 0.0719 & 0.0016 & 0.470 & 486 & 56 & 448 & 9 & 92.1 \\
\hline $104-2-C 4-2$ & 1 & 2430 & 317 & 7.67 & 30 & 2530 & 99.30 & 0.561 & 0.016 & 0.0671 & 0.0015 & 0.686 & 453 & 11 & 419 & 9 & 92.4 \\
\hline $104-1-C 3-2$ & 1 & 7330 & 1424 & 5.15 & 63 & 3254 & 99.41 & 0.509 & 0.015 & 0.0622 & 0.0016 & 0.831 & 417 & 10 & 389 & 10 & 93.3 \\
\hline $104-3-C 5-2$ & 1 & 3823 & 1387 & 2.76 & 44 & 2984 & 99.41 & 0.572 & 0.019 & 0.0691 & 0.0019 & 0.701 & 459 & 12 & 431 & 12 & 93.9 \\
\hline $104-1-C 3-4$ & 2 & 1772 & 3200 & 0.55 & 154 & 381 & 94.50 & 0.652 & 0.081 & 0.0751 & 0.0013 & 0.592 & 496 & 50 & 467 & 8 & 94.1 \\
\hline $104-2-C 4-1$ & 1 & 2409 & 1248 & 1.93 & 22 & 3761 & 99.40 & 0.578 & 0.015 & 0.0701 & 0.0019 & 0.574 & 463 & 10 & 437 & 11 & 94.3 \\
\hline $104-3-\mathrm{C} 2-1$ & 1 & 876 & 604 & 1.45 & 5 & 6020 & 99.36 & 0.533 & 0.016 & 0.0656 & 0.0014 & 0.022 & 433 & 11 & 410 & 9 & 94.5 \\
\hline $104-1-\mathrm{C} 1-7$ & 3 & 3634 & 1464 & 2.48 & 211 & 433 & 95.28 & 0.557 & 0.041 & 0.0683 & 0.0020 & 0.379 & 445 & 27 & 426 & 12 & 95.7 \\
\hline $104-3-\mathrm{C} 2-2$ & 3 & 627 & 439 & 1.43 & 124 & 155 & 86.20 & 0.530 & 0.170 & 0.0628 & 0.0018 & 0.811 & 410 & 110 & 393 & 11 & 95.8 \\
\hline $104-3-\mathrm{C} 2-4$ & 3 & 1937 & 1710 & 1.13 & 142 & 320 & 93.84 & 0.465 & 0.064 & 0.0570 & 0.0025 & 0.506 & 371 & 45 & 357 & 15 & 96.2 \\
\hline $104-1-C 3-1$ & 1 & 7240 & 673 & 10.76 & 25 & 10120 & 99.78 & 0.531 & 0.022 & 0.0680 & 0.0018 & 0.639 & 432 & 14 & 424 & 11 & 98.1 \\
\hline $104-1-C 4-2$ & 3 & 1781 & 856 & 2.08 & 1001 & 72 & 75.40 & 0.562 & 0.082 & 0.0693 & 0.0017 & 0.612 & 440 & 57 & 432 & 10 & 98.1 \\
\hline $104-1-C 5-3$ & 3 & 8380 & 5850 & 1.43 & 1383 & 137 & 86.51 & 0.526 & 0.130 & 0.0665 & 0.0024 & 0.494 & 422 & 84 & 415 & 14 & 98.4 \\
\hline $104-1-C 2-2$ & 1 & 1702 & 921 & 1.85 & 19 & 3451 & 99.73 & 0.525 & 0.015 & 0.0679 & 0.0015 & 0.269 & 428 & 10 & 424 & 9 & 98.9 \\
\hline $104-1-C 11-1$ & 1 & 2481 & 1128 & 2.20 & 12 & 7792 & 99.80 & 0.503 & 0.019 & 0.0662 & 0.0024 & 0.237 & 414 & 14 & 413 & 14 & 99.8 \\
\hline $104-2-C 5-2$ & 3 & 2575 & 1345 & 1.91 & 756 & 84 & 77.00 & 0.590 & 0.110 & 0.0722 & 0.0020 & 0.505 & 450 & 73 & 449 & 12 & 99.8 \\
\hline $104-1-C 5-1$ & 3 & 5580 & 4250 & 1.31 & 170 & 982 & 98.15 & 0.520 & 0.042 & 0.0678 & 0.0020 & 0.570 & 423 & 28 & 423 & 12 & 100.0 \\
\hline $104-1-C 1-3$ & 1 & 1283 & 641 & 2.00 & 5 & 9420 & 99.77 & 0.507 & 0.015 & 0.0667 & 0.0014 & 0.304 & 416 & 10 & 416 & 9 & 100.1 \\
\hline $104-1-C 5-2$ & 3 & 10170 & 5310 & 1.92 & 142 & 2238 & 99.19 & 0.414 & 0.013 & 0.0561 & 0.0014 & 0.265 & 351 & 9 & 352 & 8 & 100.2 \\
\hline 104-3-C3 - 1 & 3 & 2174 & 1120 & 1.94 & 467 & 130 & 86.38 & 0.538 & 0.091 & 0.0690 & 0.0019 & 0.650 & 428 & 58 & 430 & 12 & 100.5 \\
\hline $104-2-C 4-3$ & 3 & 4460 & 621 & 7.18 & 282 & 353 & 95.23 & 0.540 & 0.046 & 0.0698 & 0.0018 & 0.369 & 432 & 31 & 435 & 11 & 100.7 \\
\hline $104-3-C 5-1$ & 1 & 1039 & 547.5 & 1.90 & -1 & -39520 & 99.80 & 0.508 & 0.014 & 0.0677 & 0.0015 & 0.100 & 417 & 10 & 422 & 9 & 101.2 \\
\hline $104-1-C 3-7$ & 3 & 1454 & 1159 & 1.25 & 478 & 123 & 85.11 & 0.604 & 0.093 & 0.0732 & 0.0021 & 0.613 & 448 & 64 & 455 & 13 & 101.6 \\
\hline $104-1-C 3-5$ & 3 & 7660 & 5960 & 1.29 & 1176 & 222 & 91.95 & 0.487 & 0.030 & 0.0652 & 0.0014 & 0.600 & 400 & 20 & 407 & 8 & 101.8 \\
\hline $104-1-C 4-4$ & 3 & 2859 & 1179 & 2.42 & 179 & 415 & 95.68 & 0.494 & 0.049 & 0.0652 & 0.0019 & 0.595 & 400 & 34 & 407 & 11 & 101.8 \\
\hline $104-2-C 8-2$ & 3 & 3919 & 1532 & 2.56 & 273 & 438 & 96.03 & 0.500 & 0.051 & 0.0662 & 0.0017 & 0.503 & 406 & 35 & 414 & 10 & 101.8 \\
\hline
\end{tabular}


Table A3. Continued.

\begin{tabular}{|c|c|c|c|c|c|c|c|c|c|c|c|c|c|c|c|c|c|}
\hline \multirow[b]{2}{*}{ spot } & \multirow[b]{2}{*}{$\mathrm{C}^{*}$} & \multicolumn{5}{|c|}{ Approx. conc. (ppm) } & \multicolumn{6}{|c|}{ Final isotope ratios } & \multicolumn{5}{|c|}{ Age (Ma) } \\
\hline & & $\begin{array}{c}\mathrm{U} \\
(\mathrm{ppm})\end{array}$ & $\begin{array}{c}\text { Th } \\
(\mathrm{ppm})\end{array}$ & $\mathrm{U} / \mathrm{Th}$ & $\begin{array}{l}{ }^{204} \mathrm{~Pb} \\
\text { (cps) }\end{array}$ & $\begin{array}{c}{ }^{206} \mathrm{~Pb} / \\
{ }^{204} \mathrm{~Pb}\end{array}$ & $\% \mathrm{~Pb}^{\star \mathrm{a}}$ & $\begin{array}{c}{ }^{207} \mathrm{~Pb} / \\
{ }^{235} \mathrm{U}\end{array}$ & $2 \sigma$ & $\begin{array}{c}{ }^{206} \mathrm{~Pb} / \\
{ }^{238} \mathrm{U}\end{array}$ & $2 \sigma$ & $\begin{array}{l}\text { err. } \\
\text { corr. }\end{array}$ & $\begin{array}{c}{ }^{207} \mathrm{~Pb} / \\
{ }^{235} \mathrm{U}\end{array}$ & $2 \sigma$ & ${ }^{206} \mathrm{~Pb} /$ & $2 \sigma$ & $\begin{array}{c}\% \\
\text { conc. }^{\mathrm{b}}\end{array}$ \\
\hline $104-2-\mathrm{C} 2-1$ & 3 & 667.4 & 371.9 & 1.79 & 189 & 151 & 88.00 & 0.594 & 0.098 & 0.0744 & 0.0019 & 0.549 & 449 & 64 & 463 & 12 & 103.0 \\
\hline $104-1-C 7-1$ & 3 & 3043 & 759 & 4.01 & 309 & 255 & 92.86 & 0.481 & 0.053 & 0.0641 & 0.0018 & 0.676 & 388 & 38 & 401 & 11 & 103.3 \\
\hline $104-2-C 5-5$ & 2 & 1260 & 702 & 1.79 & 123 & 352 & 94.60 & 0.526 & 0.058 & 0.0694 & 0.0018 & 0.617 & 419 & 41 & 433 & 11 & 103.3 \\
\hline 104-1-C2 - 1 & 3 & 1515 & 1022 & 1.48 & 478 & 124 & 85.30 & 0.544 & 0.084 & 0.0706 & 0.0016 & 0.687 & 421 & 54 & 440 & 9 & 104.5 \\
\hline 104-1-C3 - 9 & 3 & 1897 & 1883 & 1.01 & 702 & 89 & 79.81 & 0.632 & 0.097 & 0.0788 & 0.0021 & 0.405 & 461 & 64 & 489 & 12 & 106.1 \\
\hline $104-1-\mathrm{C} 3-3$ & 3 & 2503 & 12300 & 0.20 & 378 & 199 & 91.33 & 0.599 & 0.066 & 0.0811 & 0.0030 & 0.403 & 460 & 41 & 502 & 18 & 109.1 \\
\hline $104-3-C 4-1$ & 3 & 1444 & 1308 & 1.10 & 526 & 103 & 83.71 & 0.710 & 0.110 & 0.0896 & 0.0025 & 0.632 & 501 & 70 & 553 & 15 & 110.4 \\
\hline $104-2-C 2-2$ & 3 & 1316 & 672 & 1.96 & 175 & 262 & 93.86 & 0.444 & 0.060 & 0.0670 & 0.0018 & 0.735 & 366 & 42 & 418 & 11 & 114.2 \\
\hline $104-3-C 7-4$ & 3 & 777 & 1077 & 0.72 & 119 & 209 & 92.30 & 0.650 & 0.130 & 0.0847 & 0.0027 & 0.598 & 456 & 84 & 524 & 16 & 114.9 \\
\hline 104-1-C7 - 2 & 3 & 2861 & 598 & 4.78 & 495 & 79 & 77.91 & 0.460 & 0.860 & 0.0677 & 0.0100 & 0.667 & 350 & 210 & 422 & 62 & 120.6 \\
\hline 104-1-C6 - 2 & 3 & 2952 & 1530 & 1.93 & 1007 & 54 & 68.00 & 0.590 & 0.150 & 0.0793 & 0.0023 & 0.716 & 407 & 100 & 492 & 14 & 120.9 \\
\hline $104-2-C 5-1$ & 3 & 3061 & 1478 & 2.07 & 1241 & 50 & 66.14 & 0.530 & 0.190 & 0.0834 & 0.0026 & 0.556 & 360 & 140 & 516 & 15 & 143.3 \\
\hline
\end{tabular}

Notes: $\mathrm{C}^{*}=$ Common $\mathrm{Pb}$ correction (1-uncorrected for common- $\mathrm{Pb}$; 2-common- $\mathrm{Pb}$ corrected using Andersen (2002) method; 3-common- $\mathrm{Pb}$ corrected using the measured $\left.{ }^{204} \mathrm{~Pb}\right)$. ${ }^{a}$ calculated from Andersen (2002) method; ${ }^{\mathrm{b}}$ calculated as $100 \times\left({ }^{206} \mathrm{~Pb} /{ }^{238} \mathrm{U}\right.$ age/ ${ }^{207} \mathrm{~Pb} /{ }^{235} \mathrm{U}$ age $)$. Samples numbers in bold and italic are used in final age calculations.

Table A4. Results for in-situ LA-ICP-MS U-Pb zircon geochronology of Sample JL16-01 (Jake Lee Mountain Granite)

\begin{tabular}{|c|c|c|c|c|c|c|c|c|c|c|c|c|c|c|c|c|c|}
\hline \multirow[b]{2}{*}{ spot } & \multirow[b]{2}{*}{$\mathrm{C}^{*}$} & \multicolumn{5}{|c|}{ Approx. conc. (ppm) } & \multicolumn{6}{|c|}{ Final isotope ratios } & \multicolumn{5}{|c|}{ Age (Ma) } \\
\hline & & $\begin{array}{c}\mathrm{U} \\
(\mathrm{ppm})\end{array}$ & $\begin{array}{c}\text { Th } \\
(\mathrm{ppm})\end{array}$ & $\mathrm{U} / \mathrm{Th}$ & $\begin{array}{l}{ }^{204} \mathrm{~Pb} \\
\text { (cps) }\end{array}$ & $\begin{array}{l}{ }^{206} \mathrm{~Pb} / \\
{ }^{204} \mathrm{~Pb}\end{array}$ & $\% \mathrm{~Pb}^{\star \mathrm{a}}$ & $\begin{array}{c}{ }^{207} \mathrm{~Pb} / \\
{ }^{235} \mathrm{U}\end{array}$ & $2 \sigma$ & $\begin{array}{l}{ }^{206} \mathrm{~Pb} / \\
{ }^{238} \mathrm{U}\end{array}$ & $2 \sigma$ & $\begin{array}{l}\text { err. } \\
\text { corr. }\end{array}$ & $\begin{array}{c}{ }^{207} \mathrm{~Pb} / \\
{ }^{235} \mathrm{U}\end{array}$ & $2 \sigma$ & $\begin{array}{c}{ }^{206} \mathrm{~Pb} / \\
{ }^{238} \mathrm{U}\end{array}$ & $2 \sigma$ & $\begin{array}{c}\% \\
\text { conc. }^{\mathrm{b}}\end{array}$ \\
\hline JL-16-01-3-C8 - 2 & 1 & 228.9 & 159.4 & 1.44 & 59 & 121 & 81.60 & 2.490 & 0.170 & 0.0872 & 0.0027 & 0.542 & 1260 & 59 & 539 & 16 & 42.8 \\
\hline JL-16-01-2-C1 - 3 & 1 & 295.2 & 277.4 & 1.06 & 57 & 186 & 89.75 & 1.367 & 0.056 & 0.0724 & 0.0017 & 0.205 & 870 & 24 & 450 & 10 & 51.8 \\
\hline JL-16-01-2-C6 - 3 & 1 & 196.3 & 125.8 & 1.56 & 61 & 130 & 90.30 & 1.327 & 1.100 & 0.0726 & 0.0081 & 0.005 & 852 & 170 & 452 & 51 & 53.0 \\
\hline JL-16-01-1-C6 - 2 & 1 & 335.1 & 355.9 & 0.94 & 37 & 312 & 93.55 & 0.977 & 0.044 & 0.0669 & 0.0015 & 0.095 & 688 & 22 & 417 & 9 & 60.6 \\
\hline JL-16-01-2-C6 - 2 & 1 & 262.3 & 249.0 & 1.05 & 53 & 187 & 94.16 & 1.050 & 0.080 & 0.0738 & 0.0018 & 0.362 & 715 & 39 & 459 & 11 & 64.2 \\
\hline JL-16-01-2-C6 - 1 & 1 & 689.9 & 721.0 & 0.96 & 81 & 330 & 94.90 & 0.923 & 0.160 & 0.0695 & 0.0028 & 0.740 & 660 & 61 & 433 & 17 & 65.6 \\
\hline JL-16-01-1-C5 - 3 & 1 & 291.4 & 224.3 & 1.30 & 25 & 388 & 95.02 & 0.908 & 0.210 & 0.0695 & 0.0025 & 0.133 & 648 & 75 & 433 & 15 & 66.9 \\
\hline JL-16-01-1-C15 - 1 & 1 & 272.1 & 233.9 & 1.16 & 3 & 2790 & 95.66 & 0.788 & 0.034 & 0.0646 & 0.0015 & 0.275 & 590 & 20 & 404 & 9 & 68.4 \\
\hline JL-16-01-2-C9 - 3 & 1 & 237.6 & 151.8 & 1.57 & 29 & 288 & 95.82 & 0.878 & 0.052 & 0.0717 & 0.0018 & 0.321 & 632 & 28 & 446 & 11 & 70.6 \\
\hline JL-16-01-3-C5 - 2 & 1 & 1183.0 & 1025.0 & 1.15 & 54 & 725 & 97.99 & 0.647 & 0.023 & 0.0662 & 0.0016 & 0.176 & 506 & 14 & 413 & 10 & 81.6 \\
\hline JL-16-01-1-C2 - 3 & 3 & 218.1 & 187.3 & 1.16 & 145 & 63 & 72.40 & 0.420 & 0.380 & 0.0656 & 0.0041 & 0.890 & 490 & 230 & 409 & 25 & 83.5 \\
\hline JL-16-01-1-C1 - 2 & 1 & 1012.0 & 1458.0 & 0.69 & 21 & 1719 & 98.31 & 0.633 & 0.019 & 0.0676 & 0.0016 & 0.060 & 497 & 12 & 421 & 10 & 84.7 \\
\hline JL-16-01-2-C2 - 2 & 3 & 311.6 & 529.0 & 0.59 & 109 & 100 & 81.07 & 0.510 & 0.280 & 0.0596 & 0.0033 & 0.879 & 440 & 180 & 373 & 20 & 84.8 \\
\hline JL-16-01-1-C15 - 2 & 1 & 341.3 & 317.7 & 1.07 & 10 & 1076 & 98.38 & 0.649 & 0.028 & 0.0693 & 0.0017 & 0.131 & 505 & 18 & 432 & 10 & 85.6 \\
\hline JL-16-01-3-C1 - 1 & 3 & 314.3 & 219.1 & 1.43 & 217 & 53 & 66.00 & 0.650 & 0.370 & 0.0692 & 0.0041 & 0.917 & 500 & 210 & 431 & 25 & 86.2 \\
\hline JL-16-01-2-C1 - 4 & 1 & 205.0 & 146.3 & 1.40 & 17 & 402 & 98.55 & 0.628 & 0.080 & 0.0686 & 0.0018 & 0.122 & 491 & 42 & 428 & 11 & 87.1 \\
\hline JL-16-01-3-C7 - 2 & 1 & 404.0 & 467.0 & 0.87 & 9 & 1428 & 98.79 & 0.562 & 0.026 & 0.0641 & 0.0015 & 0.221 & 450 & 17 & 401 & 9 & 89.0 \\
\hline JL-16-01-3-C8 - 3 & 1 & 290.0 & 204.7 & 1.42 & -3 & -3417 & 98.79 & 0.587 & 0.031 & 0.0666 & 0.0015 & 0.196 & 467 & 20 & 416 & 9 & 89.0 \\
\hline JL-16-01-2-C5 - 1 & 3 & 224.6 & 182.6 & 1.23 & 186 & 52 & 65.70 & 0.480 & 0.380 & 0.0645 & 0.0038 & 0.891 & 450 & 190 & 403 & 23 & 89.6 \\
\hline JL-16-01-3-C7 - 3 & 1 & 258.3 & 181.4 & 1.42 & -9 & -966 & 98.79 & 0.586 & 0.032 & 0.0670 & 0.0016 & 0.247 & 464 & 21 & 418 & 10 & 90.0 \\
\hline JL-16-01-2-C5 - 3 & 1 & 359.5 & 374.0 & 0.96 & 4 & 3073 & 99.03 & 0.561 & 0.027 & 0.0660 & 0.0016 & 0.136 & 450 & 18 & 412 & 10 & 91.6 \\
\hline JL-16-01-1-C2 - 2 & 1 & 251.7 & 184.5 & 1.36 & 5 & 1792 & 99.08 & 0.585 & 0.031 & 0.0686 & 0.0016 & 0.201 & 464 & 20 & 427 & 10 & 92.1 \\
\hline JL-16-01-1-C15 - 4 & 1 & 285.3 & 199.1 & 1.43 & 0 & - & 99.28 & 0.521 & 0.026 & 0.0634 & 0.0015 & 0.051 & 423 & 17 & 396 & 9 & 93.6 \\
\hline JL-16-01-1-C6 - 3 & 1 & 1523.0 & 1201.0 & 1.27 & 33 & 1738 & 99.39 & 0.565 & 0.057 & 0.0686 & 0.0017 & 0.382 & 454 & 31 & 427 & 10 & 94.1 \\
\hline
\end{tabular}


Table A4. Continued.

\begin{tabular}{|c|c|c|c|c|c|c|c|c|c|c|c|c|c|c|c|c|c|}
\hline \multirow[b]{2}{*}{ spot } & \multirow[b]{2}{*}{$\mathrm{C}^{*}$} & \multicolumn{5}{|c|}{ Approx. conc. (ppm) } & \multicolumn{6}{|c|}{ Final isotope ratios } & \multicolumn{5}{|c|}{ Age (Ma) } \\
\hline & & $\begin{array}{c}\mathrm{U} \\
(\mathrm{ppm})\end{array}$ & $\begin{array}{c}\text { Th } \\
(\mathrm{ppm})\end{array}$ & $\mathrm{U} / \mathrm{Th}$ & $\begin{array}{l}{ }^{204} \mathrm{~Pb} \\
(\mathrm{cps})\end{array}$ & $\begin{array}{l}{ }^{206} \mathrm{~Pb} / \\
{ }^{204} \mathrm{~Pb}\end{array}$ & $\% \mathrm{~Pb}^{\star^{\mathrm{a}}}$ & $\begin{array}{c}{ }^{207} \mathrm{~Pb} / \\
{ }^{235} \mathrm{U}\end{array}$ & $2 \sigma$ & $\begin{array}{c}{ }^{206} \mathrm{~Pb} / \\
{ }^{238} \mathrm{U}\end{array}$ & $2 \sigma$ & $\begin{array}{l}\text { err. } \\
\text { corr. }\end{array}$ & $\begin{array}{c}{ }^{207} \mathrm{~Pb} / \\
{ }^{235} \mathrm{U}\end{array}$ & $2 \sigma$ & $\begin{array}{l}{ }^{206} \mathrm{~Pb} / \\
{ }^{238} \mathrm{U}\end{array}$ & $2 \sigma$ & $\begin{array}{c}\% \\
\text { conc. }\end{array}$ \\
\hline JL-16-01-1-C6 - 4 & 1 & 346.0 & 230.0 & 1.50 & -1 & -12240 & 99.29 & 0.567 & 0.024 & 0.0689 & 0.0016 & 0.178 & 454 & 16 & 429 & 10 & 94.6 \\
\hline JL-16-01-3-C2 - 2 & 1 & 235.6 & 157.4 & 1.50 & -16 & -509 & 99.51 & 0.548 & 0.023 & 0.0687 & 0.0017 & 0.315 & 442 & 15 & 428 & 10 & 96.9 \\
\hline$J L-16-01-1-C 3-3$ & 1 & 223.7 & 136.1 & 1.64 & 9 & 803 & 99.60 & 0.518 & 0.039 & 0.0661 & 0.0016 & 0.109 & 421 & 25 & 412 & 10 & 98.0 \\
\hline JL-16-01-2-C5 - 2 & 1 & 178.4 & 139.0 & 1.28 & 0 & - & 99.67 & 0.546 & 0.029 & 0.0697 & 0.0017 & 0.005 & 439 & 19 & 434 & 10 & 98.9 \\
\hline JL-16-01-1-C3 - 1 & 1 & 527.7 & 776.0 & 0.68 & 10 & 1835 & 99.66 & 0.486 & 0.093 & 0.0636 & 0.0015 & 0.081 & 401 & 23 & 398 & 9 & 99.0 \\
\hline$J L-16-01-1-C 2-1$ & 1 & 243.3 & 158.2 & 1.54 & 4 & 2115 & 99.71 & 0.516 & 0.023 & 0.0671 & 0.0017 & 0.133 & 423 & 15 & 419 & 10 & 99.0 \\
\hline JL-16-01-3-C5 - 1 & 1 & 656.0 & 519.0 & 1.26 & 16 & 1493 & 99.64 & 0.529 & 0.022 & 0.0689 & 0.0019 & 0.228 & 433 & 14 & 430 & 11 & 99.2 \\
\hline$J L-16-01-2-C 1-2$ & 1 & 265.3 & 190.6 & 1.39 & -3 & -2887 & 99.74 & 0.513 & 0.025 & 0.0664 & 0.0016 & 0.010 & 417 & 17 & 415 & 10 & 99.4 \\
\hline$J L-16-01-3-C 7-1$ & 1 & 278.1 & 225.1 & 1.24 & -6 & -1625 & 99.74 & 0.519 & 0.026 & 0.0676 & 0.0016 & 0.197 & 424 & 17 & 421 & 10 & 99.4 \\
\hline$J L-16-01-2-C 1-1$ & 1 & 231.2 & 149.0 & 1.55 & -3 & -2680 & 99.72 & 0.522 & 0.031 & 0.0676 & 0.0016 & 0.005 & 424 & 20 & 422 & 10 & 99.4 \\
\hline$J L-16-01-1-C 15$ - 3 & 1 & 322.1 & 272.6 & 1.18 & 14 & 844 & 99.69 & 0.509 & 0.072 & 0.0663 & 0.0016 & 0.059 & 416 & 41 & 414 & 10 & 99.5 \\
\hline$J L-16-01-1-C 2-4$ & 1 & 346.3 & 292.8 & 1.18 & 3 & 4187 & 99.82 & 0.516 & 0.021 & 0.0672 & 0.0015 & 0.282 & 421 & 14 & 419 & 9 & 99.6 \\
\hline JL-16-01-3-C1 - 2 & 1 & 257.6 & 186.3 & 1.38 & -4 & -2198 & 99.75 & 0.513 & 0.025 & 0.0668 & 0.0015 & 0.065 & 418 & 17 & 417 & 9 & 99.8 \\
\hline$J L-16-01-1-C 6-1$ & 1 & 214.1 & 127.8 & 1.68 & -11 & -698 & 99.67 & 0.518 & 0.027 & 0.0672 & 0.0016 & 0.152 & 420 & 18 & 419 & 10 & 99.8 \\
\hline JL-16-01-1-C3 - 2 & 1 & 416.5 & 347.6 & 1.20 & 2 & 7250 & 99.72 & 0.537 & 0.024 & 0.0695 & 0.0016 & 0.304 & 434 & 15 & 433 & 10 & 99.8 \\
\hline$J L-16-01-3-C 2-1$ & 1 & 387.0 & 314.0 & 1.23 & -1 & -13200 & 99.84 & 0.504 & 0.023 & 0.0664 & 0.0015 & 0.302 & 414 & 16 & 415 & 9 & 100.1 \\
\hline$J L-16-01-1-C 5-2$ & 1 & 335.0 & 254.8 & 1.31 & 19 & 607 & 99.83 & 0.507 & & 0.0668 & 0.0016 & 0.073 & 414 & 16 & 417 & 9 & 100.6 \\
\hline JL-16-01-3-C8 - 1 & 1 & 416.8 & 314.3 & 1.33 & -5 & -2982 & 99.85 & 0.563 & 0.024 & 0.0735 & 0.0019 & 0.359 & 451 & 16 & 457 & 12 & 101.4 \\
\hline$J L-16-01-2-C 5-5$ & 1 & 258.6 & 168.9 & 1.53 & -2 & -4455 & 99.85 & 0.510 & 0.026 & 0.0675 & 0.0016 & 0.132 & 415 & 17 & 421 & 10 & 101.5 \\
\hline$J L-16-01-2-C 9-1$ & 1 & 212.7 & 137.0 & 1.55 & -6 & -1212 & 99.93 & 0.506 & 0.027 & 0.0673 & 0.0017 & 0.097 & 413 & 18 & 421 & 10 & 101.9 \\
\hline JL-16-01-2-C11 - 2 & 3 & 3790.0 & 4360.0 & 0.87 & 344 & 203 & 90.97 & 0.282 & 0.053 & 0.0394 & 0.0013 & 0.517 & 244 & 41 & 249 & 8 & 102.0 \\
\hline JL-16-01-2-C11 - 2 & 3 & 3790.0 & 4360.0 & 0.87 & 344 & 203 & 90.97 & 0.282 & 0.053 & 0.0394 & 0.0013 & 0.517 & 244 & 41 & 249 & 8 & 102.0 \\
\hline JL-16-01-2-C2 - 1 & 1 & 151.2 & 82.8 & 1.83 & 6 & 927 & 99.88 & 0.520 & 0.034 & 0.0690 & 0.0020 & 0.007 & 421 & 23 & 430 & 12 & 102.2 \\
\hline$J L-16-01-1-C 1-4$ & 2 & 3182.0 & 4550.0 & 0.70 & 106 & 1112 & 98.48 & 0.496 & 0.082 & 0.0667 & 0.0012 & 0.088 & 407 & 49 & 416 & 7 & 102.3 \\
\hline$J L-16-01-1-C 1-3$ & 1 & 7160.0 & 11790.0 & 0.61 & 117 & 1140 & 98.61 & 0.496 & 0.026 & 0.0672 & 0.0021 & 0.335 & 407 & 18 & 419 & 13 & 103.0 \\
\hline JL-16-01-3-C1 - 3 & 3 & 411.2 & 454.0 & 0.91 & 161 & 80 & 77.15 & 0.560 & 0.260 & 0.0673 & 0.0033 & 0.856 & 380 & 170 & 420 & 20 & 110.5 \\
\hline JL-16-01-3-C1 - 3 & 3 & 411.2 & 454.0 & 0.91 & 161 & 80 & 77.15 & 0.560 & 0.260 & 0.0673 & 0.0033 & 0.856 & 380 & 170 & 420 & 20 & 110.5 \\
\hline JL-16-01-1-C3 - 4 & 3 & 307.7 & 245.0 & 1.26 & 171 & 78 & 77.17 & 0.480 & 0.300 & 0.0655 & 0.0036 & 0.891 & 360 & 180 & 409 & 22 & 113.6 \\
\hline JL-16-01-1-C3 - 4 & 3 & 307.7 & 245.0 & 1.26 & 171 & 78 & 77.17 & 0.480 & 0.300 & 0.0655 & 0.0036 & 0.891 & 360 & 180 & 409 & 22 & 113.6 \\
\hline JL-16-01-2-C6 - 4 & 3 & 735.0 & 1078.0 & 0.68 & 133 & 191 & 90.52 & 0.450 & 0.130 & 0.0618 & 0.0018 & 0.548 & 330 & 87 & 387 & 11 & 117.1 \\
\hline JL-16-01-2-C6 - 4 & 3 & 735.0 & 1078.0 & 0.68 & 133 & 191 & 90.52 & 0.450 & 0.130 & 0.0618 & 0.0018 & 0.548 & 330 & 87 & 387 & 11 & 117.1 \\
\hline JL-16-01-2-C11 - 1 & 3 & 2823.0 & 2474.0 & 1.14 & 1101 & 61 & 70.69 & 0.500 & 0.100 & 0.0678 & 0.0019 & 0.732 & 360 & 66 & 422 & 12 & 117.2 \\
\hline JL-16-01-2-C11 - 1 & 3 & 2823.0 & 2474.0 & 1.14 & 1101 & 61 & 70.69 & 0.500 & 0.100 & 0.0678 & 0.0019 & 0.732 & 360 & 66 & 422 & 12 & 117.2 \\
\hline JL-16-01-2-C9 & 2 & 305.1 & 380.3 & 0.80 & 134 & 93 & 81.10 & 0.440 & 0.260 & 0.0624 & 0.0024 & 0.895 & 80 & 180 & 390 & 15 & 487.5 \\
\hline JL-16-01-2-C9 - 2 & 2 & 305.1 & 380.3 & 0.80 & 134 & 93 & 81.10 & 0.440 & 0.260 & 0.0624 & 0.0024 & 0.895 & 80 & 180 & 390 & 15 & 487.5 \\
\hline
\end{tabular}

Notes: $\mathrm{C}^{*}=$ Common $\mathrm{Pb}$ correction (1-uncorrected for common- $\mathrm{Pb}$; 2-common- $\mathrm{Pb}$ corrected using Andersen (2002) method; 3-common- $\mathrm{Pb}$ corrected using the measured ${ }^{204} \mathrm{~Pb}$ ). ${ }^{a}$ calculated from Andersen (2002) method; ${ }^{\mathrm{b}}$ calculated as $100 \times\left({ }^{206} \mathrm{~Pb} /{ }^{238} \mathrm{U}\right.$ age $/{ }^{207} \mathrm{~Pb} /{ }^{235} \mathrm{U}$ age $)$. Samples numbers in bold and italic are used in final age calculations. 
Table A5. Results for in-situ LA-ICP-MS U-Pb zircon geochronology of Sample 15-72 (Wellington Lake Granite).

\begin{tabular}{|c|c|c|c|c|c|c|c|c|c|c|c|c|c|c|c|c|c|}
\hline \multirow[b]{2}{*}{ spot } & \multirow[b]{2}{*}{$C^{*}$} & \multicolumn{5}{|c|}{ Approx. conc. (ppm) } & \multicolumn{6}{|c|}{ Final isotope ratios } & \multicolumn{5}{|c|}{ Age (Ma) } \\
\hline & & $\begin{array}{c}\mathrm{U} \\
(\mathrm{ppm})\end{array}$ & $\begin{array}{c}\text { Th } \\
(\mathrm{ppm})\end{array}$ & $\mathrm{U} / \mathrm{Th}$ & $\begin{array}{l}{ }^{204} \mathrm{~Pb} \\
(\mathrm{cps})\end{array}$ & $\begin{array}{l}{ }^{206} \mathrm{~Pb} / \\
{ }^{204} \mathrm{~Pb}\end{array}$ & $\% \mathrm{~Pb}^{*^{\mathrm{a}}}$ & $\begin{array}{c}{ }^{207} \mathrm{~Pb} / \\
{ }^{235} \mathrm{U}\end{array}$ & $2 \sigma$ & ${ }^{{ }^{206} \mathrm{~Pb} /}$ & $2 \sigma$ & $\begin{array}{l}\text { err. } \\
\text { corr. }\end{array}$ & $\begin{array}{c}{ }^{207} \mathrm{~Pb} / \\
{ }^{235} \mathrm{U}\end{array}$ & $2 \sigma$ & ${ }^{{ }^{206} \mathrm{~Pb} /}$ & $2 \sigma$ & $\begin{array}{c}\% \\
\text { conc. }\end{array}$ \\
\hline $15-72-03-12$ & 2 & 355.1 & 997.0 & 0.36 & -3 & -2147 & 99.66 & 1.579 & 0.062 & 0.0714 & 0.0014 & 0.265 & 960 & 24 & 444 & 8 & 46.3 \\
\hline $15-72-03-12$ & 2 & 355.1 & 997.0 & 0.36 & -3 & -2147 & 99.66 & 1.579 & 0.062 & 0.0714 & 0.0014 & 0.265 & 960 & 24 & 444 & 8 & 46.3 \\
\hline $15-72-03-06$ & 2 & 822.0 & 3350.0 & 0.25 & 131 & 294 & 94.30 & 1.036 & 0.041 & 0.0664 & 0.0011 & 0.065 & 722 & 21 & 415 & 7 & 57.4 \\
\hline $15-72-03-06$ & 2 & 822.0 & 3350.0 & 0.25 & 131 & 294 & 94.30 & 1.036 & 0.041 & 0.0664 & 0.0011 & 0.065 & 722 & 21 & 415 & 7 & 57.4 \\
\hline $15-72-03-11$ & 2 & 338.9 & 251.0 & 1.35 & 78 & 164 & 86.72 & 1.094 & 0.040 & 0.0707 & 0.0013 & 0.199 & 753 & 18 & 440 & 8 & 58.5 \\
\hline $15-72-03-11$ & 2 & 338.9 & 251.0 & 1.35 & 78 & 164 & 86.72 & 1.094 & 0.040 & 0.0707 & 0.0013 & 0.199 & 753 & 18 & 440 & 8 & 58.5 \\
\hline $15-72-03-10$ & 1 & 326.5 & 265.0 & 1.23 & 48 & 232 & 92.84 & 1.095 & 0.091 & 0.0714 & 0.0014 & 0.623 & 740 & 44 & 445 & 8 & 60.1 \\
\hline $15-72-03-10$ & 1 & 326.5 & 265.0 & 1.23 & 48 & 232 & 92.84 & 1.095 & 0.091 & 0.0714 & 0.0014 & 0.623 & 740 & 44 & 445 & 8 & 60.1 \\
\hline $15-72-03-07$ & 1 & 1127.0 & 3720.0 & 0.30 & 12 & 2093 & 99.20 & 0.936 & 0.077 & 0.0672 & 0.0010 & 0.560 & 668 & 41 & 419 & 6 & 62.8 \\
\hline $15-72-03-07$ & 1 & 1127.0 & 3720.0 & 0.30 & 12 & 2093 & 99.20 & 0.936 & 0.077 & 0.0672 & 0.0010 & 0.560 & 668 & 41 & 419 & 6 & 62.8 \\
\hline $15-72-03-19$ & 3 & 494.5 & 428.0 & 1.16 & 28 & 470 & 97.09 & 0.883 & 0.036 & 0.0689 & 0.0010 & 0.248 & 643 & 19 & 429 & 6 & 66.8 \\
\hline $15-72-03-19$ & 3 & 494.5 & 428.0 & 1.16 & 28 & 470 & 97.09 & 0.883 & 0.036 & 0.0689 & 0.0010 & 0.248 & 643 & 19 & 429 & 6 & 66.8 \\
\hline $15-72-03-04$ & 1 & 713.0 & 1580.0 & 0.45 & 150 & 126 & 84.80 & 0.725 & 0.025 & 0.0664 & 0.0010 & 0.250 & 553 & 14 & 415 & 6 & 75.1 \\
\hline 15-72-03-04 & 1 & 713.0 & 1580.0 & 0.45 & 150 & 126 & 84.80 & 0.725 & 0.025 & 0.0664 & 0.0010 & 0.250 & 553 & 14 & 415 & 6 & 75.1 \\
\hline $15-72-\mathrm{S} 2-\mathrm{C} 1-4$ & 1 & 517.0 & 520.0 & 0.99 & 6 & 3518 & 99.67 & 0.722 & 0.042 & 0.0670 & 0.0017 & 0.057 & 551 & 23 & 418 & 10 & 75.9 \\
\hline $15-72-03-20$ & 1 & 353.8 & 3031.0 & 0.12 & 11 & 2174 & 99.70 & 0.727 & 0.031 & 0.0677 & 0.0012 & 0.110 & 555 & 19 & 422 & 7 & 76.1 \\
\hline $15-72-03-15$ & 2 & 411.1 & 560.0 & 0.73 & -6 & -4902 & 99.69 & 0.718 & 0.029 & 0.0677 & 0.0012 & 0.309 & 550 & 17 & 423 & 7 & 76.8 \\
\hline $15-72-03-03$ & 1 & 819.0 & 621.0 & 1.32 & 42 & 622 & 96.97 & 0.705 & 0.028 & 0.0672 & 0.0010 & 0.027 & 544 & 17 & 419 & 6 & 77.1 \\
\hline 15-72-S1-C1-core - 1 & 1 & 1732.0 & 4580.0 & 0.38 & 5 & 4684 & 98.58 & 0.633 & 0.024 & 0.0650 & 0.0020 & 0.467 & 499 & 15 & 405 & 9 & 81.2 \\
\hline 15-72-S2-C1 - 3 & 1 & 307.9 & 205.4 & 1.50 & 27 & 430 & 97.21 & 0.652 & 0.044 & 0.0680 & 0.0020 & 0.044 & 508 & 26 & 426 & 11 & 83.8 \\
\hline $15-72-03-25$ & 1 & 248.0 & 308.0 & 0.81 & 5 & 5756 & 99.80 & 0.622 & 0.028 & 0.0655 & 0.0011 & 0.248 & 488 & 17 & 409 & 7 & 83.9 \\
\hline $15-72-S 2-C 2-3$ & 1 & 508.0 & 621.0 & 0.82 & 14 & 1321 & 99.82 & 0.597 & 0.035 & 0.0639 & 0.0019 & 0.522 & 473 & 22 & 399 & 12 & 84.4 \\
\hline 15-72-S1-C3 - 2 & 1 & 422.0 & 1311.0 & 0.32 & -3 & -4443 & 99.71 & 0.553 & 0.023 & 0.0614 & 0.0016 & 0.164 & 445 & 15 & 384 & 9 & 86.3 \\
\hline $15-72-\mathrm{S} 2-\mathrm{C} 2-1$ & 1 & 1096.0 & 4031.0 & 0.27 & 27 & 1011 & 98.64 & 0.604 & 0.019 & 0.0670 & 0.0020 & 0.168 & 479 & 12 & 418 & 9 & 87.1 \\
\hline 15-72-S1-C2 - 9 & 1 & 1348.0 & 650.0 & 2.07 & 6 & 1578 & 99.57 & 0.573 & 0.020 & 0.0642 & 0.0019 & 0.039 & 460 & 14 & 401 & 11 & 87.2 \\
\hline $15-72-03-14$ & 1 & 604.0 & 1810.0 & 0.33 & 23 & 679 & 97.37 & 0.576 & 0.021 & 0.0645 & 0.0011 & 0.061 & 461 & 13 & 403 & 7 & 87.4 \\
\hline $15-72-S 2-C 1-6$ & 1 & 2380.0 & 1803.0 & 1.32 & -5 & -3678 & 99.44 & 0.564 & 0.034 & 0.0646 & 0.0015 & 0.008 & 454 & 20 & 404 & 9 & 88.9 \\
\hline $15-72-\mathrm{S} 2-\mathrm{C} 1-2$ & 1 & 923.0 & 769.0 & 1.20 & 9 & 944 & 98.00 & 0.574 & 0.026 & 0.0670 & 0.0020 & 0.173 & 462 & 16 & 422 & 9 & 91.3 \\
\hline 15-72-S1-C2 - 5 & 1 & 426.8 & 140.0 & 3.05 & 4 & 5705 & 99.60 & 0.564 & 0.035 & 0.0663 & 0.0016 & 0.003 & 452 & 23 & 414 & 10 & 91.5 \\
\hline $15-72-03-08$ & 1 & 655.0 & 156.6 & 4.18 & 3 & 11220 & 99.55 & 0.579 & 0.020 & 0.0687 & 0.0009 & 0.120 & 463 & 13 & 428 & 6 & 92.4 \\
\hline $15-72-03-24$ & 1 & 755.0 & 2485.0 & 0.30 & 18 & 499 & 98.20 & 0.583 & 0.021 & 0.0690 & 0.0011 & 0.390 & 466 & 13 & 430 & 7 & 92.4 \\
\hline $15-72-S 1-C 2-7$ & 2 & 458.0 & 121.0 & 3.79 & 5 & 6354 & 99.76 & 0.516 & 0.022 & 0.0647 & 0.0016 & 0.004 & 423 & 15 & 404 & 10 & 95.6 \\
\hline $15-72-03-09$ & 1 & 926.0 & 1358.0 & 0.68 & 29 & 425 & 93.26 & 0.504 & 0.015 & 0.0634 & 0.0008 & 0.193 & 414 & 10 & 396 & 5 & 95.7 \\
\hline $15-72-03-17$ & 1 & 1054.0 & 1858.0 & 0.57 & -11 & -2623 & 99.63 & 0.530 & 0.016 & 0.0670 & 0.0009 & 0.118 & 432 & 11 & 418 & 5 & 96.8 \\
\hline 15-72-S2-C1 - 7 & 1 & 735.1 & 245.0 & 3.00 & 14 & 2013 & 98.72 & 0.534 & 0.021 & 0.0680 & 0.0020 & 0.224 & 433 & 14 & 422 & 9 & 97.4 \\
\hline $15-72-03-22$ & 2 & 396.6 & 438.3 & 0.90 & 13 & 2244 & 99.73 & 0.546 & 0.020 & 0.0693 & 0.0010 & 0.256 & 441 & 13 & 432 & 6 & 97.9 \\
\hline $15-72-S 2-C 1-1$ & 1 & 712.3 & 102.7 & 6.94 & 4 & 6870 & 99.22 & 0.508 & 0.019 & 0.0664 & 0.0014 & 0.172 & 421 & 13 & 415 & 9 & 98.5 \\
\hline $15-72-03-18$ & 1 & 749.2 & 1890.0 & 0.40 & 48 & 407 & 95.30 & 0.532 & 0.016 & 0.0685 & 0.0009 & 0.082 & 433 & 11 & 427 & 5 & 98.6 \\
\hline $15-72-S 1-C 2-6$ & 1 & 875.0 & 476.0 & 1.84 & -10 & -1155 & 99.44 & 0.511 & 0.017 & 0.0664 & 0.0014 & 0.329 & 420 & 12 & 414 & 9 & 98.7 \\
\hline 15-72-S2-C1 - 5 & 1 & 883.6 & 187.8 & 4.71 & 33 & 1382 & 98.96 & 0.504 & 0.017 & 0.0660 & 0.0020 & 0.206 & 416 & 12 & 411 & 9 & 98.7 \\
\hline $15-72-S 1-C 1-3$ & 1 & 1499.0 & 242.5 & 6.18 & 22 & 1810 & & 0.499 & 0.022 & 0.0650 & 0.0020 & 0.236 & 411 & 14 & 406 & 9 & 98.7 \\
\hline $15-72-03-23$ & 1 & 776.9 & 1283.0 & 0.61 & 6 & 5082 & 99.21 & 0.517 & 0.017 & 0.0669 & 0.0010 & 0.339 & 423 & 11 & 418 & 6 & 98.8 \\
\hline $15-72-S 2-C 2-4$ & 1 & 866.0 & 221.0 & 3.92 & 29 & 916 & 99.64 & 0.508 & 0.019 & 0.0660 & 0.0016 & 0.213 & 416 & 13 & 412 & 9 & 98.9 \\
\hline 15-72-S1-C3- 1 & 1 & 574.0 & 123.0 & 4.67 & -5 & -3398 & 99.65 & 0.495 & 0.020 & 0.0650 & 0.0015 & 0.033 & 409 & 14 & 406 & 9 & 99.2 \\
\hline $15-72-S 1-C 2-1$ & 1 & 473.0 & 307.0 & 1.54 & 41 & 272 & 99.99 & 0.505 & 0.024 & 0.0660 & 0.0016 & 0.015 & 415 & 16 & 412 & 10 & 99.2 \\
\hline $15-72-S 1-C 2-4$ & 1 & 358.2 & 105.7 & 3.39 & -16 & -773 & 99.04 & 0.499 & 0.022 & 0.0652 & 0.0015 & 0.010 & 410 & 15 & 407 & 9 & 99.3 \\
\hline $15-72-S 2-C 4-1$ & 1 & 971.0 & 405.0 & 2.40 & 4 & 4295 & 99.69 & 0.510 & 0.023 & 0.0667 & 0.0017 & 0.116 & 418 & 15 & 416 & 11 & 99.5 \\
\hline
\end{tabular}


Table A5. Continued.

\begin{tabular}{|c|c|c|c|c|c|c|c|c|c|c|c|c|c|c|c|c|c|}
\hline \multirow[b]{2}{*}{ spot } & \multirow[b]{2}{*}{$\mathrm{C}^{*}$} & \multicolumn{5}{|c|}{ Approx. conc. (ppm) } & \multicolumn{6}{|c|}{ Final isotope ratios } & \multicolumn{5}{|c|}{ Age (Ma) } \\
\hline & & $\begin{array}{c}\mathrm{U} \\
(\mathrm{ppm})\end{array}$ & $\begin{array}{c}\text { Th } \\
(\mathrm{ppm})\end{array}$ & $\mathrm{U} / \mathrm{Th}$ & $\begin{array}{l}{ }^{204} \mathrm{~Pb} \\
(\mathrm{cps})\end{array}$ & $\begin{array}{l}{ }^{206} \mathrm{~Pb} / \\
{ }^{204} \mathrm{~Pb}\end{array}$ & $\% \mathrm{~Pb}^{{ }^{\mathrm{a}}}$ & $\begin{array}{c}{ }^{207} \mathrm{~Pb} / \\
{ }^{235} \mathrm{U}\end{array}$ & $2 \sigma$ & $\begin{array}{c}{ }^{206} \mathrm{~Pb} / \\
{ }^{238} \mathrm{U}\end{array}$ & $2 \sigma$ & $\begin{array}{l}\text { err. } \\
\text { corr. }\end{array}$ & $\begin{array}{c}{ }^{207} \mathrm{~Pb} / \\
{ }^{235} \mathrm{U}\end{array}$ & $2 \sigma$ & $\begin{array}{c}{ }^{206} \mathrm{~Pb} / \\
{ }^{238} \mathrm{U}\end{array}$ & $2 \sigma$ & $\begin{array}{c}\% \\
\text { conc. }^{\mathrm{b}}\end{array}$ \\
\hline $15-72-S 1-C 2-3$ & 1 & 539.0 & 88.8 & 6.07 & -2 & -4645 & 99.83 & 0.502 & 0.024 & 0.0656 & 0.0016 & 0.011 & 412 & 17 & 410 & 10 & 99.5 \\
\hline $15-72-03-16$ & 1 & 761.4 & 192.5 & 3.96 & 7 & 5619 & 99.58 & 0.525 & 0.017 & 0.0684 & 0.0009 & 0.174 & 429 & 11 & 427 & 5 & 99.5 \\
\hline $15-72-03-01$ & 1 & 385.2 & 400.0 & 0.96 & 6 & 3912 & 99.75 & 0.512 & 0.019 & 0.0671 & 0.0011 & 0.140 & 420 & 13 & 418 & 7 & 99.6 \\
\hline 15-72-S1-C3 - 1 & 1 & 327.5 & 81.8 & 4.00 & 12 & 838 & 98.55 & 0.531 & 0.030 & 0.0690 & 0.0020 & 0.014 & 434 & 20 & 432 & 11 & 99.6 \\
\hline $15-72-S 1-C 2-8$ & 2 & 1205.0 & 266.0 & 4.53 & 9 & 3650 & 98.74 & 0.522 & 0.016 & 0.0680 & 0.0010 & 0.205 & 428 & 11 & 427 & 9 & 99.7 \\
\hline $15-72-03-21$ & 2 & 581.0 & 664.0 & 0.88 & 10 & 1544 & 99.51 & 0.540 & 0.018 & 0.0701 & 0.0011 & 0.045 & 438 & 12 & 437 & 7 & 99.7 \\
\hline $15-72-S 2-C 4-2$ & 1 & 681.4 & 208.2 & 3.27 & -5 & -24540 & 99.83 & 0.508 & 0.017 & 0.0666 & 0.0014 & 0.117 & 416 & 12 & 416 & 9 & 99.9 \\
\hline $15-72-03-02$ & 1 & 597.0 & 270.0 & 2.21 & 48 & 651 & 97.30 & 0.518 & 0.018 & 0.0678 & 0.0010 & 0.236 & 423 & 12 & 423 & 6 & 99.9 \\
\hline $15-72-03-13$ & 1 & 158.5 & 76.6 & 2.07 & 4 & 5533 & 98.67 & 0.538 & 0.031 & 0.0699 & 0.0014 & 0.014 & 433 & 21 & 436 & 8 & 100.6 \\
\hline $15-72-03-13$ & 3 & 158.5 & 76.6 & 2.07 & 4 & 5533 & 98.67 & 0.538 & 0.031 & 0.0699 & 0.0014 & 0.014 & 433 & 21 & 436 & 8 & 100.6 \\
\hline 15-72-S1-C2 - 2 & 1 & 389.8 & 236.5 & 1.65 & -24 & -902 & 99.73 & 0.486 & 0.036 & 0.0660 & 0.0020 & 0.060 & 401 & 26 & 413 & 11 & 102.9 \\
\hline
\end{tabular}

Notes: $\mathrm{C}^{*}=$ Common $\mathrm{Pb}$ correction (1-uncorrected for common- $\mathrm{Pb}$; 2-common- $\mathrm{Pb}$ corrected using Andersen (2002) method; 3-common- $\mathrm{Pb}$ corrected using the measured $\left.{ }^{204} \mathrm{~Pb}\right)$. ${ }^{\mathrm{a}}$ calculated from Andersen (2002) method; ${ }^{\mathrm{b}}$ calculated as $100 \times\left({ }^{206} \mathrm{~Pb} /{ }^{238} \mathrm{U}\right.$ age $/{ }^{207} \mathrm{~Pb} /{ }^{235} \mathrm{U}$ age $)$. Samples numbers in bold and italic are used in final age calculations.

Table A6. Results for in-situ LA-ICP-MS U-Pb monazite geochronology of a Sample 85MM-154B (John Lee Brook Granite).

\begin{tabular}{|c|c|c|c|c|c|c|c|c|c|c|c|c|c|c|c|c|c|}
\hline \multirow[b]{2}{*}{ spot } & \multirow[b]{2}{*}{$\mathrm{C}^{*}$} & \multicolumn{5}{|c|}{ Approx. conc. (ppm) } & \multicolumn{6}{|c|}{ Final isotope ratios } & \multicolumn{5}{|c|}{ Age (Ma) } \\
\hline & & $\begin{array}{c}\mathrm{U} \\
(\mathrm{ppm})\end{array}$ & $\begin{array}{c}\text { Th } \\
(\mathrm{ppm})\end{array}$ & $\mathrm{U} / \mathrm{Th}$ & $\begin{array}{l}{ }^{204} \mathrm{~Pb} \\
\text { (cps) }\end{array}$ & $\begin{array}{c}{ }^{206} \mathrm{~Pb} / \\
{ }^{204} \mathrm{~Pb}\end{array}$ & $\% \mathrm{~Pb}^{{ }^{\mathrm{a}}}$ & $\begin{array}{c}{ }^{207} \mathrm{~Pb} / \\
{ }^{235} \mathrm{U}\end{array}$ & $2 \sigma$ & $\begin{array}{l}{ }^{206} \mathrm{~Pb} / \\
{ }^{238} \mathrm{U}\end{array}$ & $2 \sigma$ & $\begin{array}{c}\text { err. } \\
\text { corr. }\end{array}$ & $\begin{array}{l}{ }^{207} \mathrm{~Pb} / \\
{ }^{235} \mathrm{U}\end{array}$ & $2 \sigma$ & ${ }^{206} \mathrm{~Pb} /$ & $2 \sigma$ & $\begin{array}{c}\% \\
\text { conc. }^{\mathrm{b}}\end{array}$ \\
\hline 85-MM-154B-C2 - 1 & 3 & 814 & 29500 & 0.03 & 139 & 30 & 41.80 & 1.570 & 0.860 & 0.0479 & 0.0064 & 0.87 & 1120 & 250 & 304 & 39 & 27.1 \\
\hline 85-MM-154B-C6 - 2 & 1 & 692 & 40440 & 0.02 & 44 & 172 & 87.28 & 1.444 & 0.061 & 0.0718 & 0.0013 & 0.137 & 905 & 27 & 447 & 8 & 49.4 \\
\hline 85-MM-154B-C4 - 2 & 1 & 1313 & 51700 & 0.03 & 47 & 154 & 87.57 & 1.510 & 0.110 & 0.0757 & 0.0021 & 0.189 & 935 & 38 & 470 & 12 & 50.3 \\
\hline 85-MM-154B-C4 - 3 & 1 & 907 & 49480 & 0.02 & 27 & 341 & 91.60 & 1.062 & 0.039 & 0.0691 & 0.0013 & 0.155 & 732 & 20 & 430 & 8 & 58.8 \\
\hline 85-MM-154B-C4 - 1 & 1 & 16 & 44620 & 0.02 & 45 & 205 & 91.61 & 1.156 & 0.048 & 0.0744 & 0.0017 & 0.458 & 775 & 23 & 463 & 10 & 59.7 \\
\hline 85-MM-154B-C10 - 2 & 1 & 954 & 43990 & 0.02 & 37 & 263 & 92.04 & 1.058 & 0.041 & 0.0714 & 0.0014 & 0.367 & 729 & 20 & 444 & 9 & 60.9 \\
\hline 85MM154B-mz6 - 3 & 1 & 50 & 48300 & 0.02 & 45 & 288 & 93.70 & 0.929 & 0.026 & 0.0706 & 0.0014 & 0.146 & 668 & 14 & 440 & 9 & 65.8 \\
\hline 85MM154B-mz3 - 3 & 3 & 490 & 22100 & 0.02 & 1100 & 36 & 57.60 & 1.240 & 2.500 & 0.0923 & 0.0220 & 0.816 & 840 & 280 & 569 & 140 & 67.7 \\
\hline 85-MM-154B-C4 - 4 & 1 & 1596 & 40240 & 0.04 & 29 & 499 & 95.38 & 0.740 & 0.026 & 0.0653 & 0.0010 & 0.234 & 562 & 15 & 408 & 6 & 72.6 \\
\hline 85-MM-154B-C12 - 2 & 1 & 489 & 43210 & 0.01 & 18 & 294 & 96.50 & 0.730 & 0.059 & 0.0697 & 0.0016 & 0.232 & 550 & 34 & 434 & 10 & 78.9 \\
\hline 85MM154B-mz5 - 3 & 1 & 818 & 55320 & 0.01 & 15 & 995 & 97.10 & 0.671 & 0.033 & 0.0663 & 0.0012 & 0.228 & 521 & 21 & 414 & 7 & 79.5 \\
\hline 85-MM-154I & 1 & 658 & 49720 & 0.01 & 2 & 4260 & 97.23 & 0.626 & 0.029 & 0.0662 & 0.0013 & 0.042 & 494 & 18 & 413 & 8 & 83.6 \\
\hline $85-\mathrm{N}$ & 1 & 386.2 & & 0.01 & 1 & 2576 & 97.41 & 0.636 & 0.037 & 0.0673 & 0.0017 & 0.1 & 498 & 23 & 419 & 10 & 84.1 \\
\hline 85MM154B-mz4 - 1 & 1 & 1714 & 71500 & 0.02 & 23 & 1061 & 97.82 & 0.601 & 0.017 & 0.0664 & 0.0010 & 0.009 & 477 & 11 & 414 & 6 & 86.9 \\
\hline 85-MM-154l & 1 & 686 & 48450 & 0.01 & 13 & 500 & 98.20 & 0.587 & 0.029 & 0.0651 & 0.0012 & 0.091 & 467 & 18 & 407 & 7 & 87 \\
\hline 85-MM-154B-C1 - 2 & 1 & 974 & 45900 & 0.02 & -4 & -1963 & 98.15 & 0.549 & 0.025 & 0.0644 & 0.0013 & 0.362 & 445 & 16 & 402 & 8 & 90.4 \\
\hline 85-MM-154B-C5 - 1 & 1 & 1164 & 48690 & 0.02 & 6 & 1727 & 98.32 & 0.549 & 0.021 & 0.0646 & 0.0011 & 0.108 & 444 & 14 & 403 & 7 & 90.9 \\
\hline 85MM154B-mz1 - 1 & 1 & 4140 & & 0.09 & 39 & 2000 & 98.67 & 0.503 & 0.089 & 0.0626 & 0.0063 & 0.469 & 413 & 47 & 392 & 38 & 94.8 \\
\hline 85MM154B-mz5 - 2 & 1 & 848 & 49580 & 0.02 & 6 & 2645 & 98.92 & 0.511 & 0.023 & 0.0639 & 0.0009 & 0.154 & 418 & 15 & 399 & 5 & 95.5 \\
\hline 85-MM-154B-C10 - 3 & 1 & 1071 & 47280 & 0.02 & -4 & -2554 & 98.98 & 0.528 & 0.022 & 0.0665 & 0.0012 & 0.055 & 430 & 15 & 415 & 7 & 96.5 \\
\hline 85MM154B-mz7 - 2 & 1 & 410 & 41500 & 0.01 & -8 & -1061 & 99.16 & 0.520 & 0.019 & 0.0667 & 0.0012 & 0.095 & 427 & 13 & 416 & 8 & 97.5 \\
\hline 85MM154B-mz6 - 1 & 1 & & & 0.01 & 2 & 3565 & 99.08 & 0.544 & 0.023 & 0.0700 & 0.0015 & 0.031 & 444 & 15 & 437 & 9 & 98.4 \\
\hline $85-M M-154 B-C 7-1$ & 1 & 1072 & 48840 & 0.02 & -7 & -1463 & 99.20 & 0.506 & 0.023 & 0.0658 & 0.0011 & 0.153 & 416 & 15 & 412 & 7 & 99 \\
\hline $85-M M-154 B-C 9-1$ & 1 & 1915 & 51600 & 0.04 & -2 & -8061 & 99.19 & 0.496 & 0.016 & 0.0650 & 0.0010 & 0.369 & 410 & 11 & 406 & 6 & 99.1 \\
\hline 85MM154B-mz7 - 1 & 1 & 738 & 73400 & 0.01 & 12 & 724 & 99.19 & 0.501 & 0.130 & 0.0651 & 0.0029 & 0.007 & 410 & 52 & 406 & 17 & 99.1 \\
\hline
\end{tabular}


Table A6. Continued.

\begin{tabular}{|c|c|c|c|c|c|c|c|c|c|c|c|c|c|c|c|c|c|}
\hline \multirow[b]{2}{*}{ spot } & \multirow[b]{2}{*}{$\mathrm{C}^{*}$} & \multicolumn{5}{|c|}{ Approx. conc. (ppm) } & \multicolumn{6}{|c|}{ Final isotope ratios } & \multicolumn{5}{|c|}{ Age (Ma) } \\
\hline & & $\begin{array}{c}\mathrm{U} \\
(\mathrm{ppm})\end{array}$ & $\begin{array}{c}\text { Th } \\
(\mathrm{ppm})\end{array}$ & $\mathrm{U} / \mathrm{Th}$ & $\begin{array}{l}{ }^{204} \mathrm{~Pb} \\
\text { (cps) }\end{array}$ & $\begin{array}{c}{ }^{206} \mathrm{~Pb} / \\
{ }^{204} \mathrm{~Pb}\end{array}$ & $\% \mathrm{~Pb}^{\star \mathrm{a}}$ & $\begin{array}{c}{ }^{207} \mathrm{~Pb} / \\
{ }^{235} \mathrm{U}\end{array}$ & $2 \sigma$ & $\begin{array}{c}{ }^{206} \mathrm{~Pb} / \\
{ }^{238} \mathrm{U}\end{array}$ & $2 \sigma$ & $\begin{array}{l}\text { err. } \\
\text { corr. }\end{array}$ & $\begin{array}{c}{ }^{207} \mathrm{~Pb} / \\
{ }^{235} \mathrm{U}\end{array}$ & $2 \sigma$ & $\begin{array}{c}{ }^{206} \mathrm{~Pb} / \\
{ }^{238} \mathrm{U}\end{array}$ & $2 \sigma$ & $\begin{array}{c}\% \\
\text { conc. }^{\mathrm{b}}\end{array}$ \\
\hline 85-MM-154B-C1 - 1 & 1 & 607.7 & 46870 & 0.01 & -4 & -1378 & 99.13 & 0.502 & 0.022 & 0.0657 & 0.0014 & 0.023 & 413 & 15 & 410 & 8 & 99.2 \\
\hline $85 M M 154 B-m z 2-2$ & 1 & 600 & 24700 & 0.02 & -2 & -11250 & 99.28 & 0.524 & 0.048 & 0.0680 & 0.0029 & 0.124 & 427 & 24 & 424 & 17 & 99.3 \\
\hline $85-M M-154 B-C 4-5$ & 1 & 1219 & 48490 & 0.03 & 6 & 1907 & 99.29 & 0.504 & 0.019 & 0.0660 & 0.0011 & 0.162 & 414 & 13 & 412 & 7 & 99.6 \\
\hline 85MM154B-mz5 - 6 & 1 & 1339 & 65410 & 0.02 & 8 & 2681 & 99.40 & 0.489 & 0.013 & 0.0646 & 0.0008 & 0.141 & 405 & 9 & 403 & 5 & 99.6 \\
\hline $85-M M-154 B-C 3-2$ & 1 & 553 & 45030 & 0.01 & 11 & 469 & 99.14 & 0.507 & 0.025 & 0.0661 & 0.0015 & 0.114 & 413 & 17 & 413 & 9 & 100 \\
\hline $85-M M-154 B-C 10-4$ & 1 & 982 & 49010 & 0.02 & 4 & 2475 & 99.29 & 0.497 & 0.019 & 0.0653 & 0.0011 & 0.295 & 408 & 13 & 408 & 7 & 100 \\
\hline $85-M M-154 B-C 10-1$ & 1 & 980 & 49170 & 0.02 & 5 & 2006 & 99.45 & 0.505 & 0.024 & 0.0661 & 0.0011 & 0.044 & 412 & 16 & 413 & 7 & 100.2 \\
\hline $85 M M 154 B-m z 6-4$ & 1 & 425 & 46900 & 0.01 & -7 & -1003 & 99.44 & 0.517 & 0.023 & 0.0682 & 0.0014 & 0.22 & 424 & 15 & 425 & 8 & 100.3 \\
\hline $85-M M-154 B-C 9-3$ & 1 & 798 & 46420 & 0.02 & 10 & 817 & 99.28 & 0.504 & 0.021 & 0.0669 & 0.0013 & 0.156 & 415 & 14 & 418 & 8 & 100.6 \\
\hline $85 M M 154 B-m z 2-1$ & 1 & 980 & 25200 & 0.04 & 3 & 9833 & 99.57 & 0.506 & 0.045 & 0.0669 & 0.0038 & 0.49 & 415 & 26 & 418 & 23 & 100.6 \\
\hline 85MM154B-mz3 - 1 & 3 & 470 & 20900 & 0.02 & 171 & 135 & 84.40 & 0.450 & 0.110 & 0.0682 & 0.0029 & 0.464 & 420 & 79 & 424 & 18 & 101 \\
\hline $85-M M-154 B-C 9-2$ & 1 & 1111 & 50980 & 0.02 & -1 & -10500 & 99.42 & 0.493 & 0.018 & 0.0659 & 0.0013 & 0.091 & 407 & 12 & 411 & 8 & 101.1 \\
\hline $85 M M 154 B-m z 6-2$ & 1 & 360 & 43500 & 0.01 & 6 & 1137 & 99.13 & 0.509 & 0.024 & 0.0679 & 0.0012 & 0.125 & 415 & 16 & 424 & 7 & 102.1 \\
\hline 85-MM-154B-C12 - 3 & 1 & 891 & 51680 & 0.02 & 11 & 812 & 99.52 & 0.491 & 0.020 & 0.0665 & 0.0013 & 0.045 & 406 & 14 & 415 & 8 & 102.2 \\
\hline 85-MM-154B-C12 - 1 & 1 & 1202 & 46850 & 0.03 & 1 & 10809 & 99.45 & 0.491 & 0.017 & 0.0665 & 0.0012 & 0.103 & 404 & 12 & 415 & 7 & 102.6 \\
\hline 85MM154B-mz5 - 4 & 3 & 946 & 58810 & 0.02 & 329 & 66 & 70.30 & 0.480 & 0.160 & 0.0689 & 0.0016 & 0.706 & 400 & 120 & 429 & 10 & 107.3 \\
\hline 85MM154B-mz4 - 2 & 2 & 11290 & 116900 & 0.10 & 99 & 1448 & 98.29 & 0.409 & 0.015 & 0.0625 & 0.0019 & 0.752 & 348 & 10 & 391 & 12 & 112.2 \\
\hline 85-MM-154B-C3 - 1 & 2 & 964 & 50200 & 0.02 & 109 & 84 & 80.10 & 0.392 & 0.010 & 0.0610 & 0.0014 & 0.949 & 336 & 7 & 381 & 9 & 113.4 \\
\hline 85MM154B-mz5 - 1 & 3 & 882 & 51600 & 0.02 & 182 & 112 & 81.83 & 0.460 & 0.130 & 0.0650 & 0.0013 & 0.695 & 290 & 110 & 406 & 8 & 140.1 \\
\hline 85MM154B-mz3 - 2 & 3 & 802 & 44020 & 0.02 & 92 & 175 & 90.81 & 0.300 & 0.380 & 0.0652 & 0.0042 & 0.605 & 240 & 120 & 407 & 26 & 169.6 \\
\hline
\end{tabular}

Notes: $\mathrm{C}^{*}=$ Common $\mathrm{Pb}$ correction (1-uncorrected for common- $\mathrm{Pb}$; 2-common- $\mathrm{Pb}$ corrected using Andersen (2002) method; 3-common- $\mathrm{Pb}$ corrected using the measured ${ }^{204} \mathrm{~Pb}$ ). ${ }^{\mathrm{a}}$ calculated from Andersen (2002) method; ${ }^{\mathrm{b}}$ calculated as $100 \times\left({ }^{206} \mathrm{~Pb} /{ }^{238} \mathrm{U}\right.$ age ${ }^{207} \mathrm{~Pb} /{ }^{235} \mathrm{U}$ age). Samples numbers in bold and italic are used in final age calculations. 